\title{
The Upper Cretaceous (Turonian) Ammonite Family Coilopoceratidae Hyatt in the Western Interior of the United States
}

GEOLOGICALSURVEY PROFESSIONALPAPER 1192

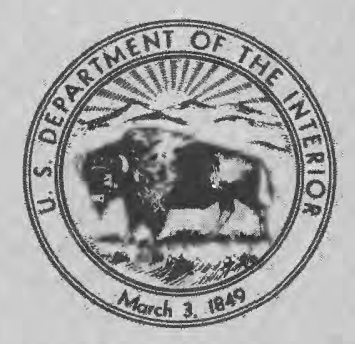




\section{The Upper Cretaceous (Turonian) Ammonite Family Coilopoceratidae Hyatt in the Western Interior of the United States}

By WILLIAM A. COBBAN and STEPHEN C. HOOK

GE O L OG I C A L S U R V E Y PROFES I O N A L P A PER 1192

Coilopoceras, Hoplitoides, and Herrickiceras, chiefly found in New Mexico, provide a means for the correlation of Cretaceous rocks between the Western Interior, South America, Africa, and Europe

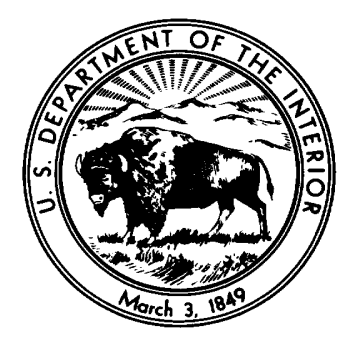


UNITED STATES DEPARTMENT OF THE INTERIOR

CECIL D. ANDRUS, Secretary

GEOLOGICAL SURVEY

H. William Menard, Director

Library of Congress Cataloging in Publication Data

Cobban, William Aubrey, 1916-

The Upper Cretaceous (Turonian) ammonite family Coilopoceratidae Hyatt in the Western Interior of the United States.

(Geological Survey Professional Paper 1192)

Bibliography: p. 24

Supt. of Docs. no: I 19.16

1. Coilopoceratidae. 2. Paleontology-Cretaceous. 3. Paleontology-The West.

I. Hook, Stephen C., joint author. II. Title. III. Series: United States Geological Survey

Professional Paper 1192.

QE807.A5C64 564'.53 80-607086

For sale by the Superintendent of Documents, U.S. Government Printing Office

Washington, D.C. 20402 


\section{CONTENTS}

Abstract . . .

Introduction

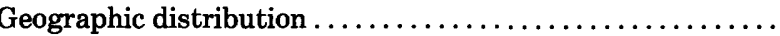

Family Coilopoceratidae Hyatt .....................

Genus Hoplitoides von Koenen, $1898 \ldots \ldots \ldots \ldots \ldots \ldots$

General statement $\ldots \ldots \ldots \ldots \ldots \ldots \ldots \ldots \ldots \ldots$

Distribution of Hoplitoides ....................

Origin of Hoplitoides .......................

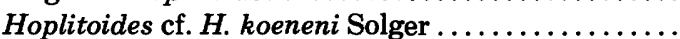

Hoplitoides cf. H. wohltmanni (von Koenen) .........

Hoplitoides sandovalensis Cobban and Hook, n. sp. .
Family Coilopoceratidae Hyatt-Continued

Genus Coilopoceras Hyatt, 1903 ..................

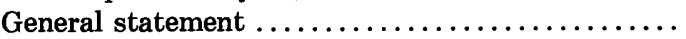

Distribution of Coilopoceras ...................

Origin of Coilopoceras .......................

Coilopoceras colleti Hyatt ....................

Coilopoceras springeri Hyatt . ..................

Coilopoceras inflatum Cobban and Hook, n. sp. .....

Genus Herrickiceras Cobban and Hook, n. gen. .........

Herrickiceras costatum (Herrick and Johnson) ......

Age relationships of Coilopoceratidae ..................

References cited
Page

11

11

12

12

13

16

19

22

23

23

24

\section{ILLUSTRATIONS}

|Plates follow index]

Plate 1. Hoplitoides and Coilopoceras.

2. Hoplitoides.

3. Coilopoceras and Hoplitoides.

4. Hoplitoides.

5-10. Coilopoceras.

11. Hoplitoides and Coilopoceras.

12-17. Coilopoceras.

18. Coilopoceras and Hoplitoides.

19. Coilopoceras and Herrickiceras.

20,21. Coilopoceras.

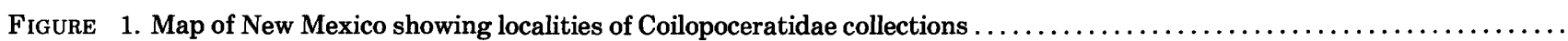

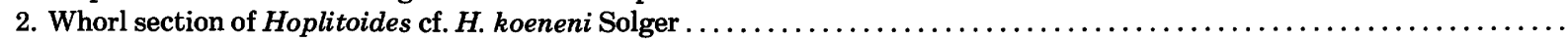

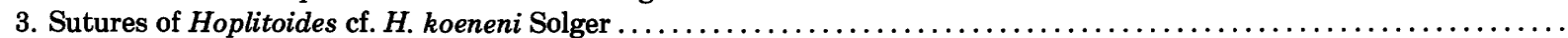

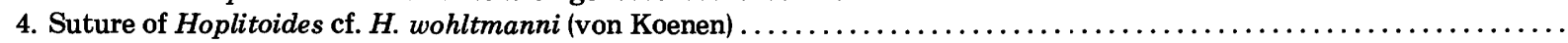

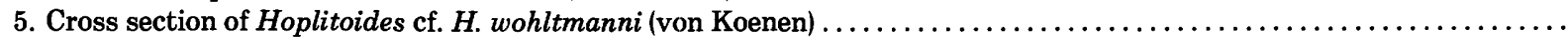

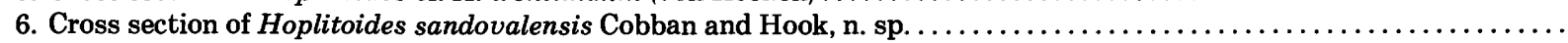

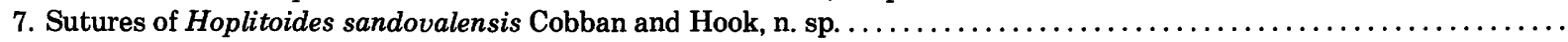

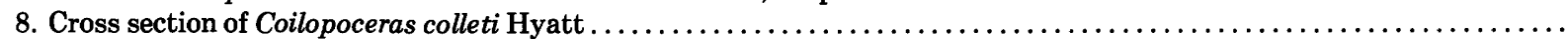

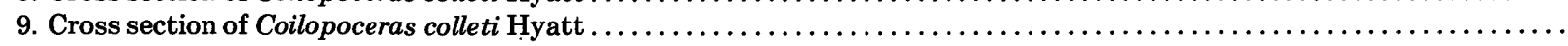

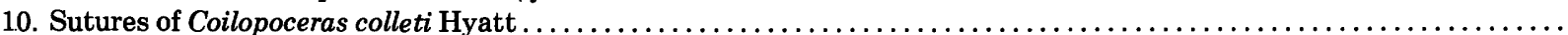

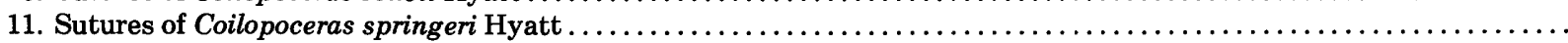

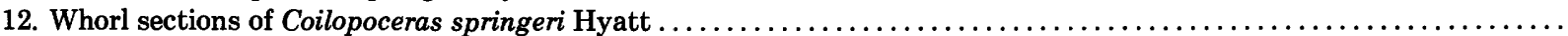

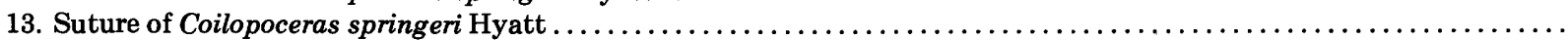

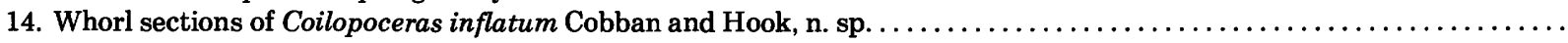

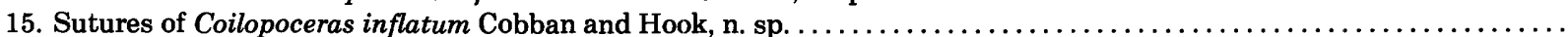

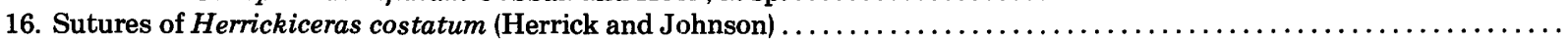




\section{TABLES}

Page

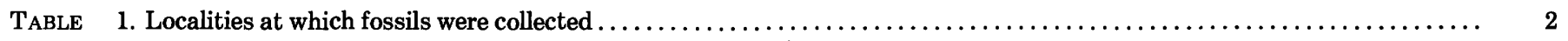

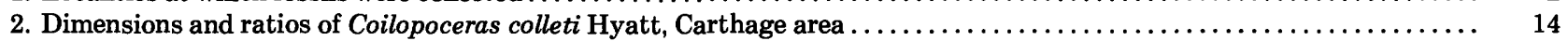

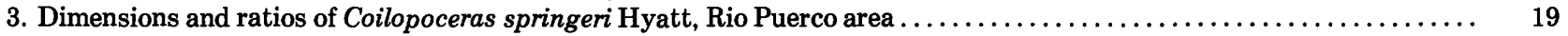

4. Dimensions and ratios of Coilopoceras inflatum Cobban and Hook, n. sp. . . . . . . . . . . . . . . . . . . . . . 


\title{
THE UPPER CRETACEOUS (TURONIAN) AMMONITE FAMILY COILOPOCERATIDAE HYATT IN THE WESTERN INTERIOR OF THE UNITED STATES
}

\author{
By William A. Cobban and Stephen C. HoOK ${ }^{1}$
}

\section{ABSTRACT}

The Coilopoceratidae include dominantly compressed involute ammonites that are either smooth or broadly ribbed and have a characteristic suture in which the bifid lateral lobe has the branch nearest the umbilicus in a more lowered position than that of the other. The family inhabited the warm waters of the Tethyan realm during part of middle Cretaceous time.

Hoplitoides, Coilopoceras, and the new genus Herrickiceras represent the family in the Western Interior. Hoplitoides, the oldest member of the family, appeared suddenly in New Mexico in the middle Turonian subzone of Collignoniceras woollgari woollgari (Mantell). The few specimens collected have affinities with $H$. koeneni Solger and $H$. wohltmanni (von Koenen) from the middle Turonian of west Africa. A little above the subzone of $C$. woollgari woollgari in New Mexico are rocks containing the new species $H$. sandovalensis associated with Herrickiceras. Coilopoceras was derived from Hoplitoides by loss of the truncated venter. The sequence of Coilopoceras in the Western Interior is, from oldest to youngest, $C$. springeri Hyatt, $C$. colleti Hyatt, and C. inflatum, $\mathrm{n}$. sp. These forms are associated with species of Prionocyclus of late middle and early late Turonian age. Herrickiceras, which appeared suddenly in New Mexico, may have had its origin in Donenriquoceras from the lower Turonian of Spain.

The Coilopoceratidae in the Western Interior are almost confined to New Mexico. A few specimens have been found in southern Colorado, and one specimen was collected in central Wyoming. Elsewhere the family is widespread in a belt on both sides of the equator in Africa, India, southern Europe, northern South America, and Mexico.

\section{INTRODUCTION}

Ammonites of the Family Coilopoceratidae preferred the warmer waters of the Tethyan region during middle Cretaceous time (Turonian). In the Western Interior region, representatives of this family are almost confined to New Mexico, where the family is known from only three genera, Coilopoceras, Hoplitoides, and the new genus Herrickiceras.

Records of Coilopoceratidae from the Western Interior are few. Hyatt (1903, p. 91-100) originally named the family and described three species of

\footnotetext{
${ }^{1}$ New Mexico Bureau of Mines and Mineral Resources, Socorro.
}

Coilopoceras from New Mexico. Aside from his paper, the only systematic work that includes a representative of the family is by Herrick and Johnson (1900, p. 214), who briefly described an ammonite as a new species, Placenticeras costata, which we are assigning to Herrickiceras. Coilopoceras has been listed from a few stratigraphic sections or localities by Lee (1912, p. $599,622,624 ; 1917$, p. 195,197$)$, Dane, Wanek, and Reeside (1957, p. 194), Dane, Cobban, and Kauffman (1966, p. H7-H9), Dane, Kauffman, and Cobban (1968, p. F9, F12, F19), and Lamb $(1968$, p. 832,835 , $836,846)$.

The specimens described in this report are in the $\mathrm{Na}-$ tional Museum of Natural History in Washington, D.C., and have USNM catalog numbers. Plaster casts of some of the specimens are in the U.S. Geological Survey's Mesozoic invertebrate fossil collections at the Denver Federal Center, Lakewood, Colo., and at the New Mexico Bureau of Mines and Mineral Resources, Socorro, N. Mex. All photographs were made by Robert E. Burkholder of the U.S. Geological Survey. The drawings of sutures and whorl sections were made by Cobban.

Ranchers who kindly gave us permission to collect from the type localities of Coilopoceras inflatum (n. sp.), C. springeri Hyatt, and C. colleti Hyatt are B. W. Cox, Red Lake ranch near D Cross Mountain northwest of Socorro, Mr. and Mrs. Gene Sauble, Sauble Circle Dot Ranch northeast of Springer, and Dean Fite, Fite Ranch near the former town of Carthage, Socorro County.

\section{GEOGRAPHIC DISTRIBUTION}

The ammonites described or recorded in this report came from 66 localities in New Mexico; a few ammonites are also recorded from Colorado and Wyoming. The localities in New Mexico are shown in figure 1, and data concerning the localities, stratigraphic position, and collectors are given in table 1 . 


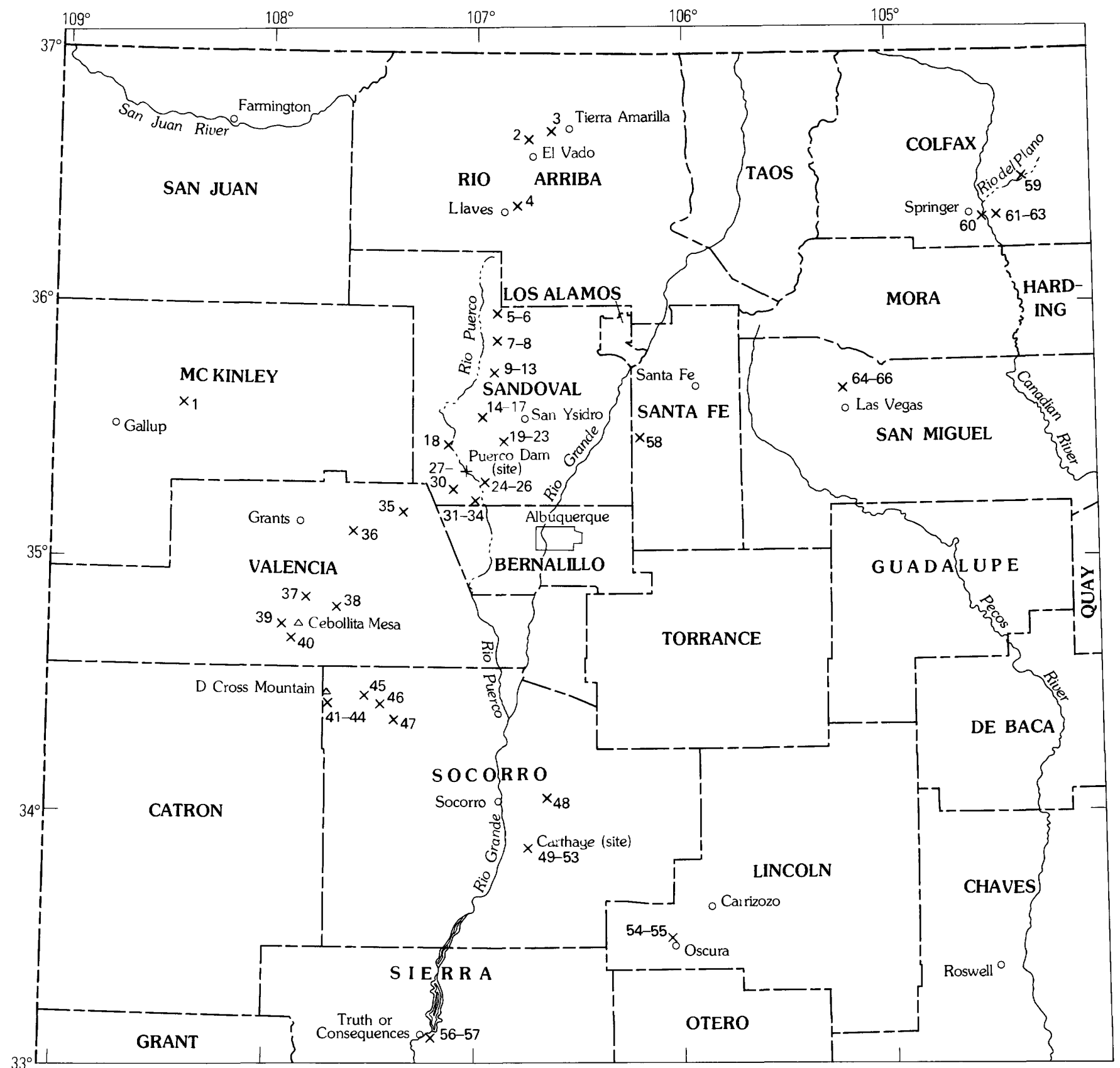

$0 \quad 102030 \quad 4050$ KILOMETERS

FIgURE 1.-Index map of New Mexico showing localities of Coilopoceratidae collections referred to in the text and in table 1.

TABLE 1.-Localities at which fossils were collected

\begin{tabular}{ccc}
\hline $\begin{array}{c}\text { Locality } \\
\text { (fig. 1) }\end{array}$ & U.S. Geological & Collector, year of collection, description of locality, \\
& Survey & and stratigraphic assignment \\
& Mesozoic & \\
& locality & \\
\hline
\end{tabular}

$1 \ldots$ D10633 J. D. Powell, 1963. Sec. 10, T. 16 N., R. 16 W., McKinley County. Juana Lopez Member of Mancos Shale.

$2 \ldots . \quad 17632 \quad$ R. P. Bryson, 1937. North of El Vado, Rio Arriba County. Mancos Shale.
TABLE 1.-Localities at which fossils were collected-Continued

\begin{tabular}{|c|c|c|}
\hline $\begin{array}{l}\text { Locality } \\
\text { (fig. 1) }\end{array}$ & $\begin{array}{l}\text { U.S. Geological } \\
\text { Survey } \\
\text { Mesozoic } \\
\text { locality }\end{array}$ & $\begin{array}{l}\text { Collector, year of collection, description of locality, } \\
\text { and stratigraphic assignment }\end{array}$ \\
\hline $3 \ldots$ & D10777 & $\begin{array}{l}\text { G. R. Scott and Juanita Scott, } 1978 . \\
\text { South of State Highway 95 and } \\
8.8 \mathrm{~km} \text { due west of Tierra Amarilla, } \\
\text { Rio Arriba County. Mancos Shale, } \\
\text { about base of Juana Lopez Member. }\end{array}$ \\
\hline
\end{tabular}


TABLE 1.-Localities at which fossils were collected-Continued

\begin{tabular}{ccc}
\hline $\begin{array}{c}\text { Locality } \\
\text { (fig. 1) }\end{array}$ & U.S. Geological & Collector, year of collection, description of locality, \\
& Survey & and stratigraphic assignment \\
& Mesozoic & \\
locality &
\end{tabular}

$4 \ldots \quad \mathrm{D} 4395$

C. H. Dane, E. R. Landis, and W. A. Cobban, 1963, North of Rio Gallina in $\mathrm{SE}^{1 / 4} \mathbf{4}$ sec. 15 , T. 25 N., R. 1 E., Rio Arriba County. Mancos Shale, base of Juana Lopez Member.

$5 \ldots \quad \mathrm{D} 4538$

C. H. Dane, 1964. Señorito Canyon in $\mathrm{SE}^{1 / 4} \mathrm{NW}^{1 / 4} \mathrm{NE}^{1 / 4}$ sec. 11 , T. $20 \mathrm{~N}$. R. 1 W., Sandoval County. Semilla Sandstone Member of Mancos Shale.

6 ... D10621 J. D. Powell, 1963. "About 200 yards north of State Highway 126 southeast of Cuba" [NW $1 / 4 \mathrm{NE}^{1 / 4} \mathrm{sec} .11, \mathrm{~T}$. 20 N., R. 1 W., Sandoval County] Mancos Shale.

$7 \ldots$ D3670 R. E. Burkholder and W. A. Cobban 1961 ; S. C. Hook, 1977. NW1/4SW1/4 SE $1 / 4$ sec. 14, T. 19 N., R. 1 W., Sandoval County. Mancos Shale, from septarian limestone concretions in silty-shale unit about $10 \mathrm{~m}$ (meters) below Juana Lopez Member.

$8 \ldots$ D10308 $\quad$ S. C. Hook, 1977 . SE $1 / 4$ SW $^{1 / 4}$ sec. 14 T. 19 N., R. 1 W., Sandoval County. Mancos Shale, from base of Juana Lopez Member.

$9 \ldots \quad$ D 3883

C. H. Dane, 1962. Arroyo Lopez, about $1 \mathrm{~km}$ (kilometer) north of Holy Ghost Spring, Sandoval County. Mancos Shale about $6 \mathrm{~m}$ above Semilla Sandstone Member.

$10 \ldots$ D3884 C. H. Dane and Ed John, 1962. Arroyo Lopez about $1 \mathrm{~km}$ north of Holy Ghost Spring, Sandoval County (Holy Ghost Spring 7.5-minute quadrangle). Basal part of Semilla Sandstone Member of Mancos Shale.

$11 \ldots$ D4014 C. H. Dane and E. R. Landis, 1963. Arroyo Lopez about $0.6 \mathrm{~km}$ north of Holy Ghost Spring, Sandoval County. Basal part of Semilla Sandstone Member of Mancos Shale.

$12 \ldots \quad$ D4016 C. H. Dane and E R West side of Arroyo Lopez $914 \mathrm{~m}$ north of Holy Ghost Spring, Sandoval County. Mancos Shale about $15 \mathrm{~m}$ above Semilla Sandstone Member.

$13 \ldots \quad 28873$

E. G. Kauffman and G. R. Paulson, 1964. Arroyo Lopez 0.6-0.9 km north of Holy Ghost Spring, Sandoval County. Basal part of Semilla Sandstone Member of Mancos Shale.

$14 \ldots$ D3702 R. E. Burkholder and W. A. Cobban, 1961. Ojo del Espiritu Santo Grant about $3.8 \mathrm{~km} \mathrm{~N}$. $60^{\circ} \mathrm{W}$. of Ojito Spring, Sandoval County. Mancos Shale, from base of Juana Lopez Shale, fror

$15 \ldots$ D4020 C. H. Dane, 1963. About $1.6 \mathrm{~km}$ south west of Ojito Spring, Ojo del Espiritu Santo Grant, Sandoval County. Basal part of Semilla Sandstone Member of Mancos Shale.

$16 \ldots \quad \mathrm{D} 4414$

C. H. Dane, 1963. NW1/4SW1/4 sec. 17 , T. 15 N., R. 1 W., Sandoval County. Semilla Sandstone Member of Mancos Shale.

$17 \ldots \quad$ D4417
TABLE 1.-Localities at which fossils were collected-Continued

\begin{tabular}{lcc}
\hline $\begin{array}{l}\text { Locality } \\
\text { (fig. 1) }\end{array}$ & U.S. Geological & Collector, year of collection, description of locality, \\
& Survey & and stratigraphic assignment \\
& Mesozoic & \\
& locality & \\
\hline
\end{tabular}

$\mathrm{km} \mathrm{S} .10^{\circ} \mathrm{W}$. of Ojito Spring, Ojo del Espiritu Santo Grant, Sandoval County, Mancos Shale.

$18 \ldots 7992 \quad$ W. T. Lee and T. W. Stanton, 1912 About $5.6 \mathrm{~km}$ south of Casa Salazar (sec. 11, T. 14 N., R. 3 W.), Sandoval County. Mancos Shale.

$19 \ldots$ D6790 E. R. Landis, 1968. Near center of sec. 6, T. 14 N., R. 1 E., Sandoval County. Mancos Shale, $18 \mathrm{~m}$ above top of Semilla Sandstone Member.

20 ... D6791 E. R. Landis, 1968. NW1/4NE $1 / 4$ sec. 5 T. 14 N., R. 1 E., Sandoval County. Mancos Shale, about $11.5 \mathrm{~m}$ below base of upper ledges of Juana Lopez Member.

$21 \ldots$ D10575 L. F. Gunther and W. A. Cobban, 1965. $\mathrm{N}^{1} 1 / 2$ sec. 6 , T. 14 N., R. 1 E. Sandoval County. Semilla Sandstone Member of Mancos Shale.

$22 \ldots \quad$ D10634 L. F. Gunther. Probably in sec. 6, T. 14 N., R. 1 E., Sandoval County. Mancos Shale.

$23 \ldots$ C. B. Hunt and J. W. Wyckoff, 1931 NW $1 / 4$ NW $1 / 4$ sec. 5, T. 14 N., R. 1 E., Sandoval County. Mancos Shale.

$24 \ldots \quad 7204 \quad$ W. T. Lee, 1911. About $4.8 \mathrm{~km}$ north of San Francisco and east of Rio Puerco, Bernabe M Montano Grant, Sandoval County. Mancos Shale, from unit of shale that contains limestone concretions.

$25 \ldots \quad 15792 \quad$ C. B. Hunt, 1931. Northeastern part of Bernabe M Montano Grant, Sandoval County. Mancos Shale.

$26 \ldots$ C. $15795 \quad$ C. Hunt, 1931. Bernabe M Montano Grant, $305 \mathrm{~m}$ west of east line and $2,743 \mathrm{~m}$ south of north line; Sandoval County. Mancos Shale.

$27 \ldots \quad$ D10508

Neal La Fon, 1977-78; S. C. Hook and W. A. Cobban, 1978. NE $1 / 4 \mathrm{NW}^{1 / 4}$ sec. $7, \quad T .12$ N., R. 2 W. (unsurveyed), Agua Salada Grant, Sandoval County. Mancos Shale, from the cephalopod zone underlying the Semilla Sandstone Member.

$28 \ldots \quad 15925$

C. B. Hunt and J. W. Wyckoff, 1931. Agua Salada Grant, $274 \mathrm{~m}$ north of south line and $914 \mathrm{~m}$ west of east line, Sandoval County. Mancos Shale.

$29 \ldots \quad 15947$

C. B. Hunt, H. R. Joesting, J. W. Wyckoff, G. F. Taylor, and R. C Becker, 1931; S. C. Hook and S. J. Frost, 1978. Agua Salada Grant, 305 $\mathrm{m}$ north of south line and 1,524 m west of east line, Sandoval County. Mancos Shale.

$30 \ldots \quad 15799$

C. B. Hunt, 1931. NE $1 / 4 \mathrm{NE}^{1 / 4}$ sec. 15 , T. 12 N., R. 2 W. (unsurveyed), Sandoval County. Mancos Shale.

$31 \ldots 3672 \quad$ T. W. Stanton and J. G. Walthers, 1906. "Rio Puerco, 5 miles above San Ignacio." Mancos Shale.

$32 \ldots \quad$ D10469

S. C. Hook, E. A. Merewether, and W. A. Cobban, 1978. About 1,372 m west of the southeast corner of Puerco Dam 71/2-minute quadrangle, Sandoval County. Mancos Shale.

$33 \ldots \quad \mathrm{D} 10622$
Neal La Fon, 1978. Bernabe M Montano Grant, 1,524 m west and $305 \mathrm{~m}$ south of northeast corner of Herrera 
TABLE 1.-Localities at which fossils were collected-Continued

\begin{tabular}{ccc}
\hline $\begin{array}{c}\text { Locality } \\
\text { (fig. 1) }\end{array}$ & $\begin{array}{c}\text { U.S. Geological } \\
\text { Survey }\end{array}$ & $\begin{array}{c}\text { Collector, year of collection, description of locality, } \\
\text { and stratigraphic assignment }\end{array}$ \\
& $\begin{array}{c}\text { Mesozoic } \\
\text { locality }\end{array}$ & \\
& &
\end{tabular}

\begin{tabular}{|c|c|}
\hline $34 \ldots$ & 15797 \\
\hline $35 \ldots$ & D10602 \\
\hline $36 \ldots$ & D5340 \\
\hline $37 \ldots$ & D10551 \\
\hline $38 \ldots$ & D10321 \\
\hline $39 \ldots$ & D7071 \\
\hline $40 \ldots$ & D2055 \\
\hline
\end{tabular}

71/2-minute quadrangle, Sandoval County. Mancos Shale, about $7.6 \mathrm{~m}$ below top of Juana Lopez Member.

C. B. Hunt and others, 1931. Bernabe M Montano Grant, 3,962 $\mathrm{m}$ west of east line and $9,449 \mathrm{~m}$ north of south line; Sandoval County. Mancos Shale.

E. R. Landis and C. H. Maxwell, 1969; S. C. Hook, 1978. Head of arroyo 3.1 $\mathrm{km} \mathrm{N} .12^{\circ} \mathbf{E}$. of Moquino, Valencia County. Mancos Shale, below lowest ledge of Juana Lopez Member.

E. R. Landis and W. A. Cobban, 1966. San Jose Canyon in SW $1 / 4$ SW $^{1 / 4} \mathrm{sec}$. 4, T. 10 N., R. 7 W., Valencia County. Mancos Shale, $14.6 \mathrm{~m}$ above a sandy unit.

S. C. Hook, 1978. SW1/4SE1/4SE1/4 sec. 5, T. 7 N., R. 9 W., Valencia County. D-Cross Tongue of Mancos Shale.

J. R. Wright, 1977. NW $3 / 4 N^{1 / 4 N^{1} 1 / 4}$ sec. 22 , T. 7 N., R. 8 W., Valencia County. About $2 \mathrm{~m}$ above base of D-Cross Tongue of Mancos Shale.

C. M. Molenaar, 1969. Southwest side of Cebollita Mesa in sec. 17, T. 6 N., R. 10 W., Valencia County. Base of D-Cross Tongue of Mancos Shale.

C. H. Dane, G. O. Bachman, and W. A. Cobban, 1959. South end of Cebollita Mesa in sec. 34, T. 6 N., R. 10 W., Valencia County. Basal $3 \mathrm{~m}$ of D-Cross Tongue of Mancos Shale.

S. C. Hook and J. W. Wright, 1979.

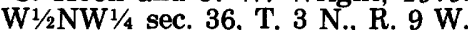
(unsurveyed), Catron County. Basal $2 \mathrm{~m}$ of D-Cross Tongue of Mancos Shale.

$42 \ldots \quad$ D7066

C. M. Molenaar, 1969. Southeast of $D$ Cross Mountain in NE $1 / 4 \mathrm{NE}^{1 / 4} \mathrm{sec}$. 30, T. 3 N., R. 8 W., Socorro County. Basal $2 \mathrm{~m}$ of D-Cross Tongue of Mancos Shale.

$43 \ldots \quad$ D10299

$44 \ldots \quad 26203$

$45 \ldots \quad$ D5773

$46 \ldots \quad D 10259$

$47 \ldots \quad 8336$
G. L. Massingill, 1977. NE1/4NE1/4 sec. 30, T. 3 N., R. 8 W., Socorro County. Basal $2 \mathrm{~m}$ of D-Cross Tongue of Mancos Shale.

G. O. Bachman and J. B. Reeside, Jr., 1956. SE $1 / 4$ sec. 25, T. 3 N., R. 9 W., Socorro County. Basal part of D-Cross Tongue of Mancos Shale.

W. A. Cobban, 1967. NW1/4NW1/4 sec. 24, T. 3 N., R. 7 W., Socorro County. Mancos Shale, from lower part of Tres Hermanos Sandstone Member.

S. C. Hook and W. A. Cobban, 1977. SW $1 / 4$ NE $1 / 4$ sec. 33 , T. 3 N., R. 6 W. Socorro County. From lower part of Tres Hermanos Sandstone Member of Mancos Shale.

D. E. Winchester, H. M. Robinson, and W. T. Thom, Jr., 1913. SW1/4SE1/4 sec. 20 , T. 2 N., R. 5 W., Socorro County. Mancos Shale, from "first prominent sandstone above Dakota" (Tres Hermanos).

S. C. Hook, D. E. Tabet, and J. R Wright, 1977. SW $1 / 4$ NE $1 / 4$ sec. 8, T. 3 S., R. 3 E., Socorro County. Mancos Shale, from limestone concretions below Tres Hermanos Sandstone Member.
TABLE 1.-Localities at which fossils were collected-Continued

\begin{tabular}{|lcc}
\hline $\begin{array}{c}\text { Locality } \\
\text { (fig. 1) }\end{array}$ & $\begin{array}{c}\text { U.S. Geological } \\
\text { Survey } \\
\text { Mesozoic } \\
\text { locality }\end{array}$ & $\begin{array}{c}\text { Collector, year of collection, description of locality, } \\
\text { and stratigraphic assignment }\end{array}$ \\
\hline $49 \ldots$ & D2042 & W. A. Cobban, 1959. SW1/4 sec. 9, \\
& T. 5 S., R. 2 E., Socorro County. \\
& $\begin{array}{l}\text { Mancos Shale, about 15 m below top } \\
\text { of Tres Hermanos Sandstone } \\
\text { Member. }\end{array}$
\end{tabular}

$50 \ldots \quad$ D7076 Member.

C. M. Molenaar, 1969. Center N1/2N1/2 sec. 15, T. 5 S., R. 2 E., Socorro County. Mancos Shale, about $15 \mathrm{~m}$ below top of Tres Hermanos Sandstone Member.

$51 \ldots \quad$ D10354

Christina Lochman-Balk and students; S. C. Hook and David Kalvelage, 1976 . N1/2 SW1/4 sec. 9, T. 5 S., R. 2 E., Carthage area, Socorro County. Mancos Shale, about $15 \mathrm{~m}$ below top of Tres Hermanso Sandstone Member.

$52 \ldots$ D10356 J. R. Wright, $1975,1976 . \mathrm{NW}^{1 / 4}$ sec. $16, T .5$ S. R 2 E., Socorro County. Mancos Shale, about $15 \mathrm{~m}$ below top of Tres Hermanos Sandstone Member.

$53 \ldots \quad$ D10630

S. C. Hook, 1978. NE1/4NE1/4SE $1 / 4$ sec 9 T 5 S R 2 E., Socorro County. Mancos Shale, upper part of Tres Hermanos Sandstone Member.

$54 \ldots \quad$ D10636

S. C. Hook, J. R. Wright, D. E. Tabet, and Donald Wolberg, 1979.

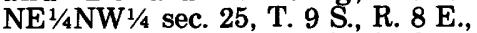
Lincoln County. Mancos Shale, from sandstone concretions at top of Tres Hermanos Sandstone Member.

$55 \ldots \quad$ D10644

S. C. Hook, 1979. SW1/4 SE $1 / 4$ sec. 24, T. 9 S., R. 8 E., Lincoln County. Mancos Shale, from sandstone concretions at top of Tres Hermanos Sandstone Member.

$56 \ldots \quad$ D7841

Bruce Black, 1969. Mescal Canyon, sec. 36, T. 13 S., R. 4 W., Sierra County. Near base of D-Cross Tongue of Mancos Shale.

$57 \ldots \quad$ D10707

J. R. Wright, 1979 . NW1/4NW1/4 sec. 1 , T. $14 \mathrm{~S}$, R. $4 \mathrm{~W}$., (unsurveyed), Sierra County. Near base of D-Cross Tongue of Mancos Shale.

$58 \ldots \quad$ D10811

S. C. Hook and W. A. Cobban, 1979. NW $^{1 / 4}$ SE $^{1 / 4}$ sec. 33 , T. 15 N., R. 7 E., Santa Fe County. Mancos Shale, from limestone concretions about $0.6 \mathrm{~m}$ above base of Juana Lopez Member.

$59 \ldots \quad$ D10739

S. C. Hook and J. R. Wright, 1979. Rio del Plano, SE $1 / 4 \mathrm{NE}^{1 / 4}$ sec. 13, T. 26 N., R. 24 E., Colfax County. Carlile Shale, from concretions below Juana Lopez Member.

$60 \ldots \quad D 10740$

S. C. Hook, 1979. West bank of Canadian River $6.4 \mathrm{~km}$ east of Springer, Colfax County. Carlile Shale, from concretions below Juana Lopez Member.

$61 \ldots \quad$ D10785

S. C. Hook, 1979. SW $1 / 4 \mathrm{NE}^{1 / 4}$ sec. 2, T. 24 N. R. 23 E., Colfax County. Carlile Shale, from limestone concretions below Juana Lopez Member.

$62 \ldots \quad$ D10789

S. C. Hook and W. A. Cobban, 1979. Same locality as 60. Carlile Shale, from limestone concretions $0.3 \mathrm{~m}$ above base of Juana Lopez Member.

$63 \ldots \quad$ D10791
S. C. Hook and W. A. Cobban, 1979. SE $1 / 4 N^{1 / 4}$ sec. 11 , T. 24 N., R. 23 E. Colfax County. Carlile Shale, from 
TABLE 1.-Localities at which fossils were collected-Continued

\begin{tabular}{|c|c|c|}
\hline $\begin{array}{l}\text { Locality } \\
\text { (fig. } 1)\end{array}$ & $\begin{array}{l}\text { U.S. Geological } \\
\text { Survey } \\
\text { Mesozoic } \\
\text { locality }\end{array}$ & $\begin{array}{l}\text { Collector, year of collection, description of locality, } \\
\text { and stratigraphic assignment }\end{array}$ \\
\hline $64 \ldots$ & D10772 & $\begin{array}{l}\text { limestone concretions } 0.3 \mathrm{~m} \text { above } \\
\text { base of Juana Lopez Member. } \\
\text { S. C. Hook and E. H. Baltz, Jr., } 1979 . \\
\text { Inlet canal to Storrie Lake } 90 \mathrm{~m} \\
\text { west of State Highway 3, San } \\
\text { Miguel County. Carlile Shale, from } \\
2.4 \mathrm{~m} \text { above base of Juana Lopez } \\
\text { Member. }\end{array}$ \\
\hline $65 \ldots$ & D10796 & $\begin{array}{l}\text { S. C. Hook, 1979. About } 0.4 \mathrm{~km} \text { east } \\
\text { of State Highway } 3 \text { and intersection } \\
\text { of dirt road just north of BR } 6620 \text { in } \\
\text { Las Vegas NW } 71 / 2-\text { minute quad- } \\
\text { rangle, San Miguel County. Carlile } \\
\text { Shale, from a limestone concretion } \\
4.6 \mathrm{~m} \text { above base of Juana Lopez } \\
\text { Member. }\end{array}$ \\
\hline $66 \ldots$ & D10797 & $\begin{array}{l}\text { W. A. Cobban, 1979. Same locality } \\
\text { as } 65 \text {. Carlile Shale, from a limestone } \\
\text { concretion } 6.7 \mathrm{~m} \text { above base of } \\
\text { Juana Lopez Member. }\end{array}$ \\
\hline
\end{tabular}

Family COILOPOCERATIDAE Hyatt

Hyatt $(1903$, p. 88) defined this family mainly on the nature of the suture. Wright $(1957, p$. L424) gave a much better definition as follows:

"Moderately to very involute, more or less compressed forms, either flat-sided with flat venter that becomes narrowly rounded in adult or cordate or lanceolate in section with sharp venter; at some stage broad, low, rounded ribs spring in pairs from low umbilical tubercles or bulges. Suture characterized by very broad, shallow first lateral lobe divided by one or more accessory saddles."

Hyatt included only his new genera Coilopoceras and Aconeceras in the family. Wright excluded Aconeceras and placed Coilopoceras, Hoplitoides von Koenen, and Glebosoceras Reyment in the Coilopoceratidae. Glebosoceras (Reyment, 1954a, p. 161), originally described from the Turonian of Nigeria, resembles Coilopoceras except that the ribs bend sharply forward on the outer part of the flank. The genus has not been found in New Mexico and probably does not occur in North America. Young and Powell (1976, p. 25.26) considered Coilopoceras chispaense Adkins (1931, p. 48, pl. 4, figs. 5, 7; pl. 5, fig. 2) a Glebosoceras, but C. chispaense lacks the forwardly bent ribs of Glebosoceras, and we believe Adkin's species is merely the robust and ornamented form of C. springeri Hyatt (1903, p. 96$)$.

\section{Genus HOPLITOIDES von Koenen, 1898}

\section{GENERAL STATEMENT}

Hoplitoides is a slender, involute ammonite that has a sulcate to flat venter on the early whorls and a sharply rounded to narrowly rounded venter on the later whorls. Early whorls may have weak to moderately strong, somewhat sigmoidal ribs crossing most of the flank with some arising from umbilical bullae. Adult whorls are smooth or nearly so. The suture is characterized by a broad lateral lobe that tends to be deeply bifid and to have one or both of its two branches deeply bifid. The rest of the lobes of the external suture are much smaller than the lateral one and decrease regularly in size away from it.

Hoplitoides is abundant and well preserved in a hard, bluish-gray limestone unit along the Mungo River between Mundame and Eliki in Cameroon. Von Koenen (1897, p. 11-13) described from there three closely related ammonites which he named Neoptychites? (Hoplites) lentiformis (1897, p. 11, pl. 2, figs. 1, 4, 7), Neoptychites? (Hoplites) wohltmanni (1897, p. 12, pl. 1, fig. 2; pl. 2, figs. 3, 9), and Neoptychites? ingens (1897, p. 12 , pl. 1, fig. 4; pl. 2, figs. 5, 8). Shortly thereafter, von Koenen $(1898$, p. 53) named the new genus Hoplitoides, assigned his Neoptychites? ingens, N.? (Hoplites) lentiformis, and N.? (H.) wohltmanni to it, and described the new species $H$. latesellatus (1898, p. 56, pl. 6, figs. 1-3), $H$. wilsingi (1898, p. 59, pl. 5, fig. 2; pl. 6, figs. 6, 7), and $H$. n. sp.? (1898, p. 61 , pl. 5, fig. 1 ; pl. 6 , fig. 5). In his earlier paper, von Koenen $(1897$, p. 9 , pl. 1, fig. 5a-c) described from this locality another ammonite that he named Pulchellia gibbosula, but in his 1898 paper, he questioned the generic assignment.

Friedrich Solger in 1904 studied the same fauna from the Mungo River locality. He (1904) devoted many pages and illustrations to Hoplitoides and considered $H$. latesellatus as the type of the genus. Hoplitoides wohltmanni was emended, and von Koenen's Neoptychites? (Hoplites) lentiformis was assigned to it. Solger also revised $H$. ingens, named three new varieties of it (nodifer, costatus, laevis), and assigned to this species von Koenen's $H$. wilsingi, $H$. n. sp.?, and one of von Koenen's two figured specimens of $H$. latesellatus. Von Koenen's Pulchellia gibbosula was assigned to Hoplitoides, and a new subspecies (bipartitus) was described. Solger (1904, p. 151, pl. 4, figs. 8, 9) also described the new species $H$. koeneni.

The Mungo River fauna was studied again in 1932 by Leonhard Riedel, who figured $H$. gibbosulus and several very good specimens of $H$. ingens, including unusually large individuals. Riedel also described two new species, $H$. autenriethi $(1932$, p. 126 , text fig. 36$)$ and $H$. solgeri $(1932$, p. 132 , pl. 27 , figs. 2 , 3; text fig. 37).

Reyment (1955b, p. 77-83) discussed Hoplitoides from Nigeria and figured specimens of $H$. ingens, $H$. gibbosulus, $H$. koeneni, and a new species $H$. crassicostatus (Reyment, 1955b, p. 83, pl. 17, figs. 3, 4; text 
fig. 41) as well as the new subspecies $H$. gibbosulus makurdiensis. He pointed out that the type of Hoplitoides should be Neoptychites? ingens von Koenen (1897), inasmuch as $H$. latesellatus von Koenen (1898), designated the type species by von Koenen, is a synonym of $H$. ingens. Other species regarded as synonyms of $H$. ingens by Reyment are $H$. wilsingi and $H$. solgeri. Hoplitoides autenriethi is regarded as a synonym of $H$. gibbosulus bipartitus Solger.

The Hoplitoides beds of Nigeria and Cameroon contain a great variety of forms ranging from slender, nearly smooth types (for example, $H$. wohltmanni and $H$. ingens laevis) to stout, well ornamented ones $(H$. gibbosulus and $H$. crassicostatus). That these forms occur together is shown by Reyment $(1955 \mathrm{~b}, \mathrm{p} .98,99)$. The ammonites from New Mexico that we are assigning to Hoplitoides do not show this range in variation.

\section{DISTRIBUTION OF HOPLITOIDES}

Hoplitoides has been recorded from 15 countries in the Tethyan Belt. References that mostly include illustrated specimens are as follows: Mexico (Böse, 1918, p. 225-227), Peru (Brüggen, 1910, p. 735, 736; Benavides-Cáceres, 1956, p. 475, 476); Columbia (Bürgl, 1957, pl. 16; Reyment, 1970, p. 914), Venezuela (Renz, 1959, p. 42), Trinidad (Reyment, 1970, p. 914; 1972, p. 360-364), Brazil (Magalhães, 1952, p. 15-17; Oliveira and Brito, 1969, p. 223-226), Nigeria and Cameroon (von Koenen, 1898, p. 56-61; Solger, 1904, p. 127-157; Riedel, 1932, p. 125-133; Reyment, 1955b, p. 77-83), Tunisia (Pervinquière, 1907, p. 217-223, Algeria (Collignon, 1965b, p. 193, 194), Egypt (Eck, 1915, p. 193-196; Douvillé, 1928, p. 28-31), Israel (Freund and Raab, 1969, p. 63-66), Lebanon (Basse, 1937, p. 189-191; 1940, p. 461), Jordan (Gioffredi and others, 1976, p. 41), and Spain (Wiedmann, 1959, p. $711,712,720$ ). Nearly all of these records are from Turonian rocks. The genus was also recorded from Madagascar (Basse, 1953).

Most records of Hoplitoides are from the lower Turonian. Brüggen (1910, p. 735) recorded the genus from the Coniacian of northern Peru, but Benavides-Cáceres (1956, p. 475, 476) found it only in the lower Turonian of that region. Bürgl (1957, pl. 16, fig. 2a, b) gave a Turonian and Coniacian age for specimens from Colombia.

In the Western Interior, Hoplitoides has been found only in New Mexico, where it is represented by three species of middle Turonian age. The oldest species, $H$. cf. $H$. wohltmanni (von Koenen) and $H$. cf. $H$. koeneni Solger, occur sparsely in the lower part of the zone of Collignoniceras woollgari (Mantell), and the youngest species, $H$. sandovalensis Cobban and Hook, n. sp., oc- curs in the next overlying zone of Prionocyclus hyatti (Stanton). The ammonite, recorded by Lee (1912, p. $624 ; 1917$, p. 197) as Coilopoceras colleti, is $H$. sandovalensis.

\section{ORIGIN OF HOPLITOIDES}

Hoplitoides appears suddenly early in the middle Turonian in the Western Interior of the United States. Its origin has to be elsewhere. The type species, $H$. ingens (von Koenen), is abundant in the Turonian of Nigeria and Cameroon. Reyment $(1955 b$, p. 98,99$)$ at first assigned the species to the lower Turonian, but recently he (Reyment, 1976, p. 20.2, 20.12) considered a middle Turonian age more acceptable. Specimens referred to this species have been recorded from the lower Turonian of Tunisia (Pervinquière, 1907, p. 219), Egypt (Eck, 1915, p. 194), Lebanon (Basse, 1940, p. 461), Spain (Wiedmann, 1959, p. 712), Trinidad (Reyment, 1970, p. 914), Colombia (Reyment, 1970, p. 914), and Brazil (Reyment, 1971, p. 1070), and specimens compared to it have been recorded from Peru (Brüggen, 1910 , p. 735 ).

Reyment (1954b, p. 260) would derive the Coilopoceratidae in part from the Pseudotissotiidae and in part from the lower Turonian genus Bauchioceras. Later, Reyment (1955b, p. 70) was more specific and suggested the origin of the Coilopoceratidae from Wrightoceras, which, in turn, was derived from Bauchioceras. In this scheme, Hoplitoides would be derived from Wrightoceras, and Glebosoceras and Coilopoceras would be derived from Hoplitoides. Barber (1957, p. 62) disagreed with this interpretation, and pointed out that Coilopoceras "occurs at a horizon several hundred feet below Bauchioceras" at a locality in Nigeria.

Perhaps Hoplitoides originated in some other genus, such as Choffaticeras, which is widespread in the Tethyan region in early Turonian rocks usually a little older than those containing Hoplitoides. The suture of Choffaticeras recalls that of Hoplitoides in having an asymmetrically bifid, broad lateral lobe, of which the part nearest the venter is higher than the part away from it. For many examples of the suture of Choffaticeras, see Freund and Raab (1969, text figs. 10-13).

\section{Hoplitoides of. H. koeneni Solger}

Plate 1, figures 1,2 ; plate 3 , figures 4,5 ; text figures 2,3

Hoplitoides koeneni Solger (1904, p. 151, pl. 4, figs. 8,9 ; test figs. 42,43 ) has moderately slender whorls, of which the early ones are ribbed. The venter is broadly truncated out to a rather large diameter. Solger described the ribs as broad and wavelike and attaining their greatest height on the outer part of the flank. He gave a count of 10 for one-half whorl. Two specimens 
were illustrated, a small one that shows the flank ribbing in a lateral view and a larger one that shows an end view. The end view reveals a conspicuous truncation of the venter to a diameter of at least $37 \mathrm{~mm}$ (millimeters) and a narrowly rounded venter at a diameter of $57 \mathrm{~mm}$. Several external sutures were illustrated by Solger, but none is from a whorl exceeding $23 \mathrm{~mm}$ in "Windungsradius" (a little more than the whorl height). These sutures are rather simple for the genus.

A partly crushed specimen (pl. 2, figs. 1, 2), $76 \mathrm{~mm}$ in diameter, from a limestone concretion in the upper part of the Mancos Shale underlying the Tres Hermanos Sandstone Member, shows considerable resemblance to $H$. koeneni. This specimen, from USGS Mesozoic locality D10260 (fig. 1, loc. 48), has a little more than one-half whorl of the body chamber preserved. The last whorl of the phragmocone has a narrow sulcate venter $2 \mathrm{~mm}$ wide at a diameter of about $33 \mathrm{~mm}$ (fig. 2). The venter is poorly preserved on the body chamber, but it appears to be narrowly truncated. Ten low, broad, straight ribs per one-half whorl are present on the phragmocone (pl. 3, fig. 5). These ribs are strongest on the outer part of the flank, and every second or third extends to the umbilical shoulder. The ribs weaken on the body chamber and almost disappear. The suture is difficult to see, and only part of it could be drawn (fig. $3 A$ ). A simple pattern is revealed, and in this manner it resembles the suture of H. koeneni at comparable diameters (Solger, 1904, text figs. 42b, 43b; Reyment, $1955 \mathrm{~b}$, text fig. 37a). The specimen seems to differ from $H$. koeneni only in its narrower venter. No other ammonites were found with this specimen, but Mammites depressus Powell was collected from about the same stratigraphic position at a nearby locality (USGS Mesozoic loc. D10377 in $\mathrm{SE}^{1 / 4} \mathrm{NW}^{1 / 1} / 4$ sec. 5 , T. 3 S., R. 3 E.).

Another specimen of Hoplitoides, which has a simple suture comparable to that of $H$. koeneni and the specimen from locality D10260, is represented by a moderately slender phragmocone $98 \mathrm{~mm}$ in diameter from USGS Mesozoic locality 8336 (fig. 1, loc. 47). This phragmocone has a narrow, truncated venter to a diameter of at least $64 \mathrm{~mm}$. The venter is not preserved on the next one-fourth whorl, but it is narrowly rounded at a diameter of $78 \mathrm{~mm}$. About eight broad, very weak ribs are present per one-half whorl. Most of the external suture is shown in figure $3 B$. This suture also resembles some of the simpler sutures of $H$. ingens (von Koenen) figured by Solger (1904, text figs. 29b, c, 39b, 41b). The New Mexico specimen was associated with Collignoniceras woollgari woollgari (Mantell).

Types.-Figured specimens USNM 252968, 275876.
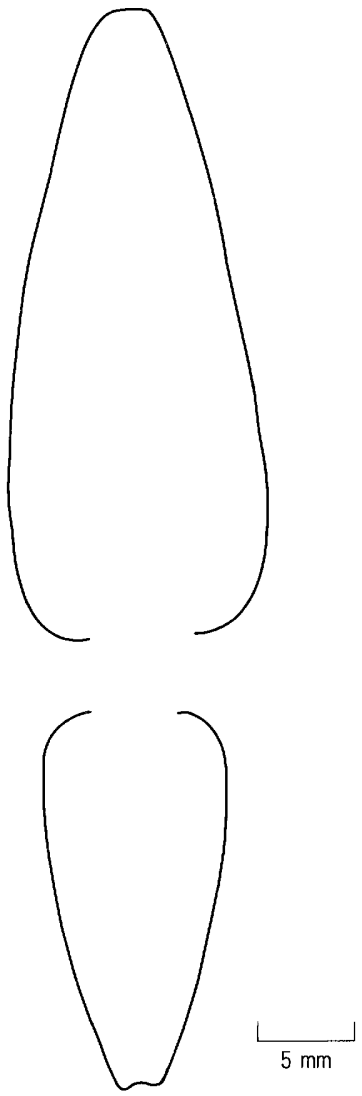

FIGURE 2.-Whorl section (restored) of Hoplitoides cf. H. koeneni Solger at a diameter of $55 \mathrm{~mm}$. From USGS Mesozoic locality D10260 (fig. 1, loc. 48). Figured specimen USNM 252968 (pl. 1, figs. 1, 2).

\section{Hoplitoides of. H. wohltmanni (von Koenen)}

Plate 1, figures, 3, 4; text figures 4, 5

Three specimens from the basal part of the Tres Hermanos Sandstone Member of the Mancos Shale, (fig. 1, loc. 45) resemble Hoplitoides wohltmanni (von Koenen, 1897 , p. 12, pl. 1, fig. 2; pl. 2, figs. 3, 9) in the whorl section and suture. One of the specimens, a phragmocone $95 \mathrm{~mm}$ in diameter (pl. 1, figs. 3, 4), is almost smooth and has a moderately digitate suture (fig. 4) much like those illustrated by von Koenen (1897, pl. 2, fig. 9) and Solger (1904, text figs. 25-27) for $H$. wohltmanni as well as some sutures of $H$. ingens (von Koenen) figured by Solger (1904, text figs. 34c, d). The specimen differs from von Koenen's species in having a truncated venter out to a much greater diameter. The venter of the New Mexico specimen is truncated out to a diameter of at least $65 \mathrm{~mm}$, beyond which the venter is not preserved until near the end of the specimen, where the venter is narrowly rounded at a diameter of $91 \mathrm{~mm}$. A larger specimen, from the same locality, is part of a smooth phragmocone whose cross section (fig. 5) is like 


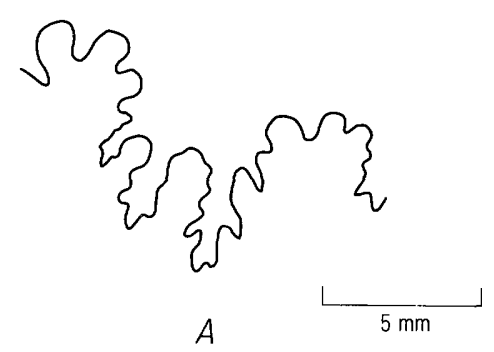

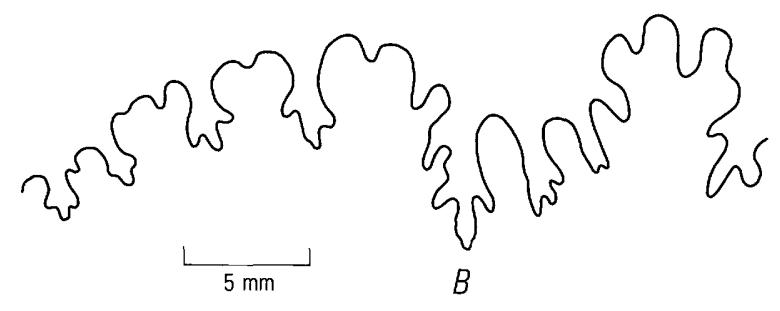

Figure 3.-Part of the external sutures of Hoplitoides cf. $H$. koeneni Solger. $A$, figured specimen USNM 252968 (pl. 1, figs. 1, 2) at a diameter of $37.5 \mathrm{~mm}$, from USGS Mesozoic locality D10260 (fig. 1, loc. 48). $B$, figured specimen USNM 275876 at a diameter of about $64 \mathrm{~mm}$, from USGS Mesozoic locality 8336 (fig. 1, loc. 47). Heavy line marks middle of venter.

that of $H$. wohltmanni (von Koenen, 1897, pl. 2, fig. 3). The third specimen, from USGS Mesozoic locality D10259 (fig. 1, loc. 46), is a small phragmocone that has a narrowly truncated venter out to a diameter of $35 \mathrm{~mm}$; the venter is not preserved beyond that size.

Types.-Figured specimens USNM 252969, 255609.

Hoplitoides sandovalensis Cobban and Hook, n. sp.

Plate 2; plate 3, figures 6-8, 12-16; plate 4; plate 11, figure 1; plate 18, figures 4-6; text figures 6, 7

This species is characterized by its slender section, early disappearance of the truncated venter, and complex suture. The species has been found only in Sandoval County, N. Mex., where it is represented by 22 specimens from six localities. Umbilical ratios range from 0.04 to 0.09 and thickness ratios range from 0.24 to 0.30 .

A septate fragment $122 \mathrm{~mm}$ in diameter was selected as the holotype because it reveals an inner whorl that has a sulcate venter and several later whorls that have sharp venters (pl. 2, figs. 6, 7). All visible whorls have their maximum thickness near the umbilicus. Whorl sections of a small paratype are shown in figure 6 . The

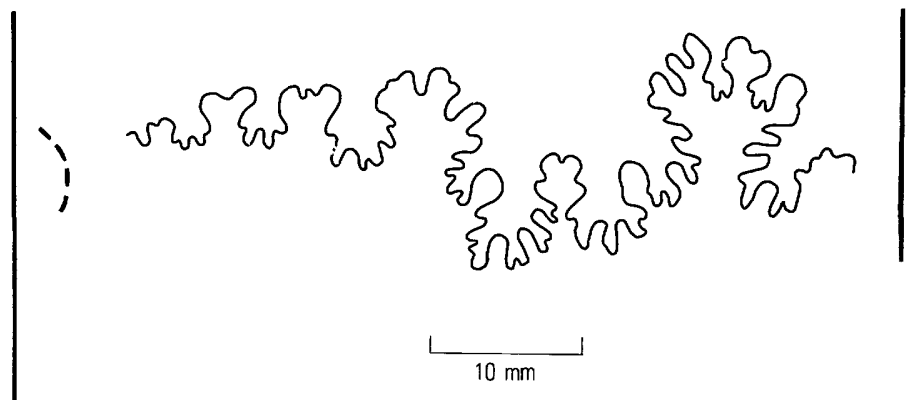

Figure 4.-External suture of Hoplitoides cf. $H$. wohltmanni (von Koenen) at a diameter of $\mathbf{9 1 . 5} \mathbf{m m}$, from USGS Mesozoic locality D5773 (fig. 1, loc. 45). Figured specimen USNM 252969 (pl. 1, figs. 3 , 4). Heavy line marks middle of venter. Dashed line marks umbilical seam. From Cobban and Hook (1979, text fig. 11).

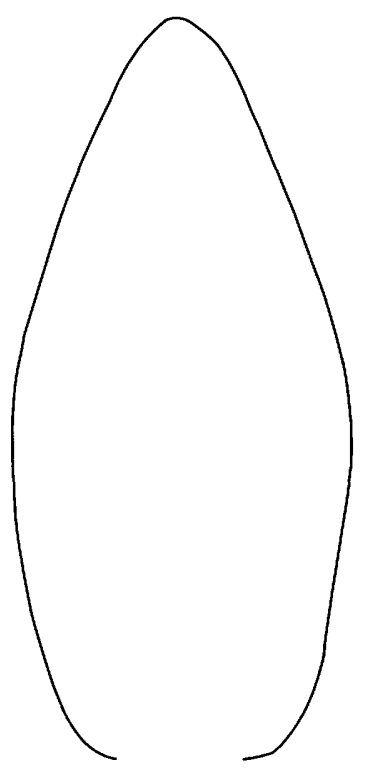

Figure 5.-Cross section through the older part of a body chamber of Hoplitoides cf. $H$. wohltmanni (von Koenen) from USGS Mesozoic locality D5773 (fig. 1, loc. 45). Figured specimen USNM 255609. From Cobban and Hook (1979, text fig. 10).

innermost whorls of the holotype are not exposed, but at a diameter of about $11 \mathrm{~mm}$, the venter is very narrow and sulcate. The venter becomes sharp at some diameter between 11 and $20 \mathrm{~mm}$. On two paratypes, from the same locality as the holotype, the sulcate venter flattens and then sharply rounds at diameters of 29 and $35 \mathrm{~mm}$ (pl. 2, figs. 1-3; pl. 3, figs. 6-8).

The whorls of the holotype are almost smooth, but under oblique lighting, faint, broad, slightly flexuous ribs are discernible even on the smallest visible whorl at a diameter of about $11 \mathrm{~mm}$. The ribs are highest near the venter on the innermost visible whorl. The in- 


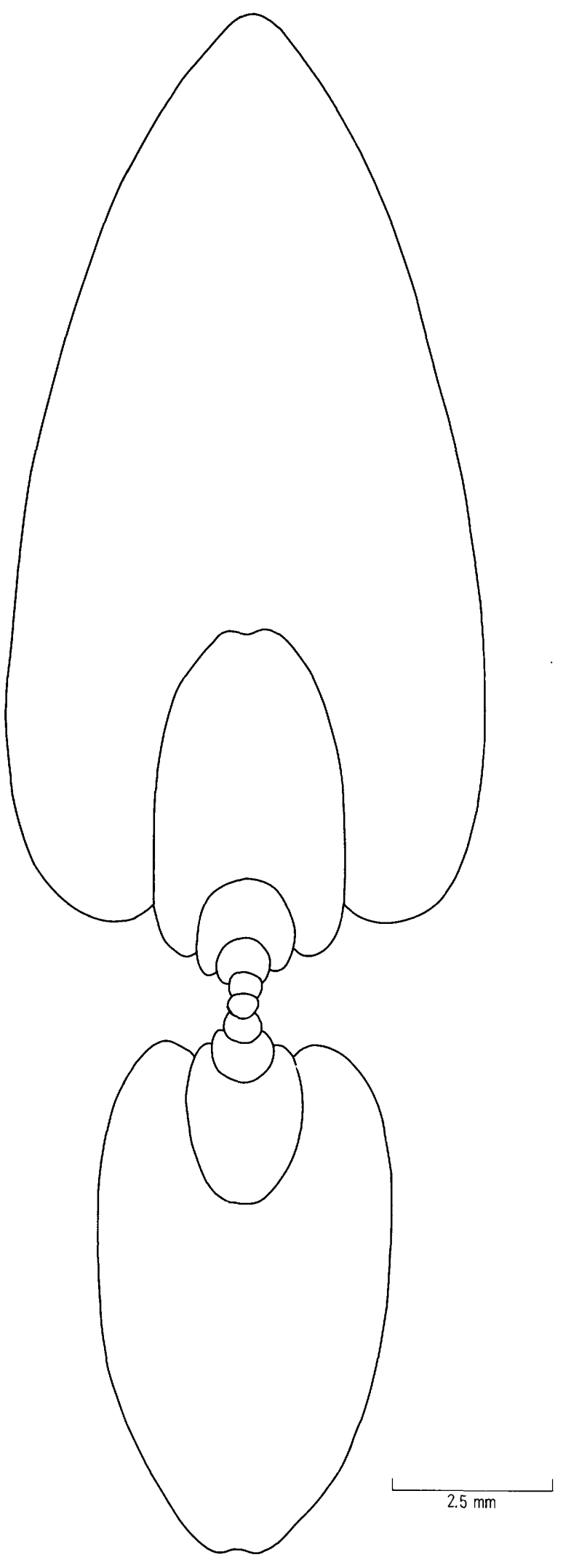

ner one-third to one-half of the flank is devoid of ribs. Ribbing is so faint on this species that counts are difficult and uncertain even under oblique lighting. The few counts that could be made with any certainty were seven or eight per one-half whorl.

Hoplitoides sandovalensis is large. One specimen in the collections is septate at $198 \mathrm{~mm}$, but larger specimens were seen in the field. The paratype figured on plate 4 has a diameter of $207 \mathrm{~mm}$ at the base of the body chamber.

The suture is more deeply digitate than that of most figured sutures of Hoplitoides (fig. 7). The first lateral lobe is very broad and divided by three or four long branches. The first lateral saddle is high and narrow and much divided by long branches.

Hoplitoides sandovalensis has a very large Coilopoceras-like siphuncle that is separated by a small, hollow area from the shell forming the venter. The ventral shell material is thin and easily removed on weathering, which exposes the siphuncle. Where the siphuncle is eroded, the hollow venter typical of weathered Coilopoceras is formed (pl. 3, figs. 12, 13).

Hoplitoides sandovalensis resembles the African species described by von Koenen $(1898$, p. 58 , pl. 5 , fig. 3; pl. 7, figs. 4, 5) as $H$. ingens in having an early loss of the sulcate venter. The whorl sections of large specimens of $H$. ingens are more inflated than those of $H$. sandovalensis, and studies by Solger (1904, p. 137-151), Riedel (1932, p. 128-132), and Reyment (1955b, p. 79-81) revealed that $H$. ingens is a variable species ranging from nearly smooth to costate with some individuals having umbilical bullae.

The African species described by von Koenen (1897, p. 12, pl. 1, fig. 2; pl. 2, figs. 3, 9) as Neoptychites? (Hoplites) wohltmanni and later assigned to Hoplitoides by Solger $(1904$, p. 133) resembles $H$. sandovalensis in its slender section and nearly smooth shell but differs in retaining the truncated venter to a larger size as well as in having a bifid first lateral lobe.

The species of Hoplitoides from Brazil, described by Magalhães (1952, p. 15, text fig. 2; 1953, p. 49, text figs. 1, 2) and Oliveira and Brito (1969, p. 223-225, pl. 3 ; text figs. 5,6 ), resemble $H$. sandovalensis in having smooth or nearly smooth shells, but differ in having simple sutures. The inner whorls of the Brazilian species have not been described or illustrated.

Figure 6.-Cross section through the inner whorls of Hoplitoides sandovalensis Cobban and Hook, n. sp. Paratype USNM 275885 (pl. 18, figs. 4-6) from USGS Mesozoic locality D10508 (fig. 1, loc. 27). 


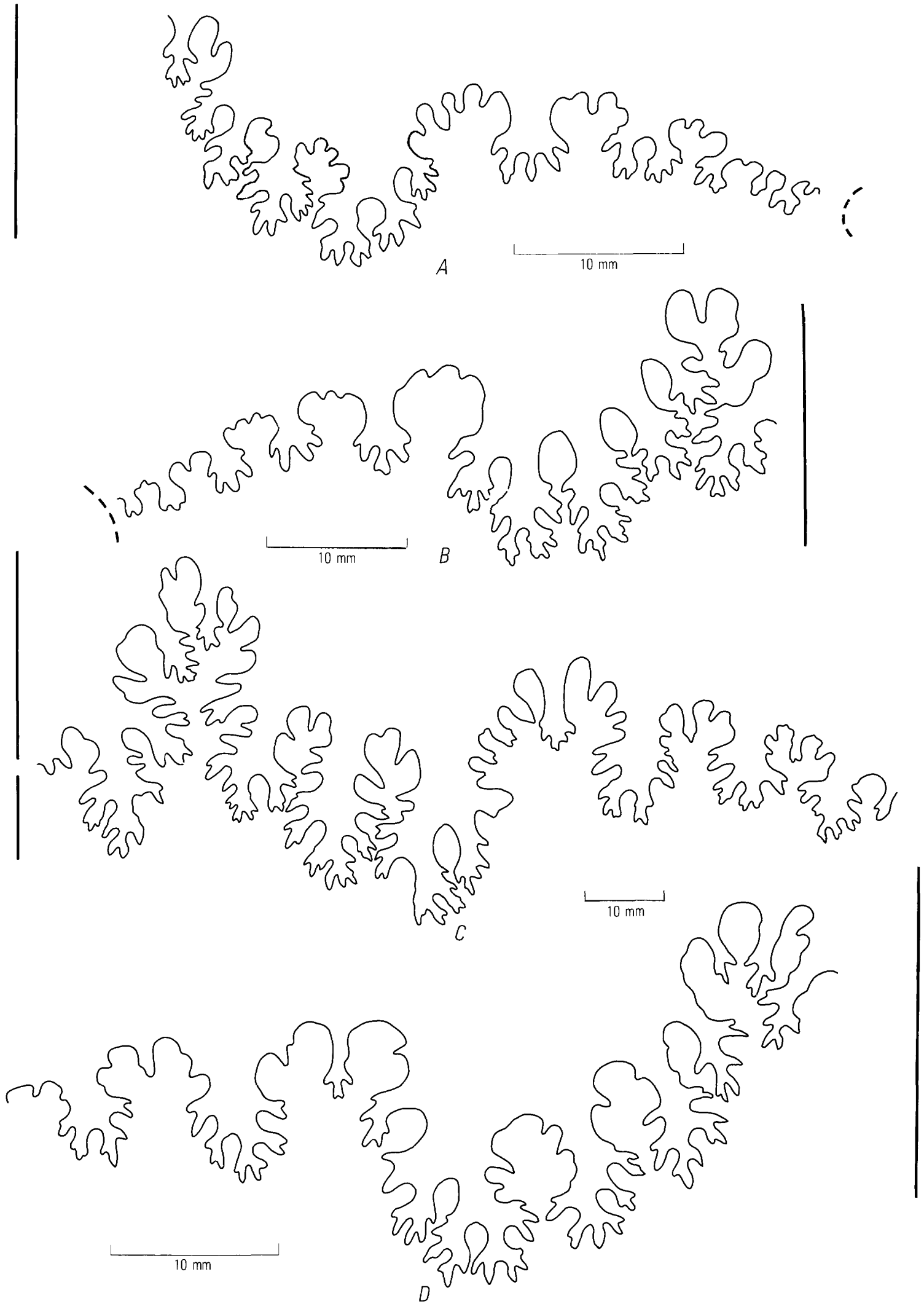


Hoplitoides hourcqui Collignon (1965b, p. 193, pl. F, figs. 3a, b), from the lower Turonian of Algeria, resembles $H$. sandovalensis in its nearly smooth shell and slender section, but the African species has a wider umbilicus (ratios 0.12-0.15) and a simpler suture characterized by a broad first lateral saddle and bifid first lateral lobe.

Other species of Hoplitoides differ from $H$. sandovalensis in having broader whorls, stronger ornamentation, truncated venter at larger diameters, or important differences in the suture.

Hoplitoides sandovalensis has been found only in the Rio Puerco valley in southwestern Sandoval County (fig. 1, locs. 24-32, 34). Specimens occur in limestone concretions in the Mancos Shale. Other ammonites in the collections with $H$. sandovalensis are Spathites puercoensis (Herrick and Johnson), Prionocyclus hyatti (Stanton), Proplacenticeras pseudoplacenta (Hyatt), and Shuparoceras.

Types.-Holotype USNM 275877, paratypes USNM 275878-275885.

\section{Genus COILOPOCERAS Hyatt, 1903}

GENERAL STATEMENT

Coilopoceras is a slender to robust, involute ammonite that has a narrow, sharp venter on early whorls and a narrowly rounded to well-rounded venter on later whorls. Species in the Western Interior are dimorphic; one form is more compressed than the other and tends to be smooth or nearly so. The stouter form has broad, foldlike primary ribs, narrower secondary ribs, and, on some specimens, low, rounded ventrolateral tubercles.

Coilopoceras has a very diagnostic and unusual suture. The lateral lobe is very broad and deeply bifid, and the two branches (accessory lobes) also tend to be deeply bifid. On most specimens the branch farthest from the venter is in a more lowered or adapical position, and its bifurcating saddle is not as deep as that of the other branch. The rest of the lobes of the external suture are much smaller than the lateral one and decrease regularly in size toward the umbilicus. These smaller lobes are bifid or trifid and number five or six.

Douvillé $(1911$, p. 308,309$)$ studied the external sutures of a few species of Coilopoceras and concluded that the older species had more symmetrically bifid lateral lobes than those of younger forms. In his study

Figure 7.-External sutures of Hoplitoides sandovalensis Cobban and Hook, n. sp. A, Paratype USNM 257881 (pl. 3, figs. 15, 16) from USGS Mesozoic locality 15797 (fig. 1, loc. 34). B, Paratype USNM 275883 (pl. 3, figs. 12-14) from USGS Mesozoic locality 3672 (fig. 1, loc. 31). C, Paratype USNM 257884 (pl. 4) from USGS Mesozoic locality D10508 (fig. 1, loc. 27). $D$, Paratype USNM 275880 (pl. 2, figs. 8-10) from USGS Mesozoic locality 15799 (fig. 1, loc. 30 ).
Douvillé (1911, text fig. 37) designated by numbers and letters the major divisions of the lateral lobe.

Hyatt (1903, p. 91) was impressed by the hollow keel of Coilopoceras and, hence, the source of the generic name. The siphuncle is very large, and where exposed on weathering, it has the appearance of a tube that has periodic constrictions at the intersections with the septae (pl. 1, fig. 9; pl. 10, figs. 1, 3, 5, 6; Hyatt, 1903, pl. 10, fig. 2; Barber, 1957, pl. 3, figs. 1a, 2b). This condition is well shown on weathered specimens of other ammonites similar to Coilopoceras, such as Hoplitoides hourcqui Collignon (1965b, pl. F, fig. 3b), $H$. ingens (von Koenen) (Riedel, 1932, pl. 24), Glebosoceras glebosum Reyment (Collignon, 1965a, pl. 402, fig. 1686), the ammonites figured by Eck (1915, pl. 16, fig. 3; pl. 19, fig. 2) as Pseudotissotia segnis Solger and Tissotia schweinfurthi Eck, and those figured by Douvillé (1928, pl. 3, fig. 7b; pl. 4, fig. 1b; pl. 5 , fig. $1 \mathrm{~b}$ ) as Leoniceras quassi Peron and $L$. segne Solger, the latter two probably being species of Choffaticeras according to Freund and Raab $(1969$, p. 56 , $60)$. A very conspicuous concave venter was formed on specimens that had the siphuncle removed by weathering (pl. 3, figs. 7, 8) (Hyatt, 1903, pl. 10, fig. 2; Parnes, 1964, pl. 1, fig. 8).

Coilopoceras was very large. The holotype of $C$. springeri Hyatt is $400 \mathrm{~mm}$ in diameter. The types of $C$. eaglefordense Adkins and C. chispaense Adkins have diameters of $525 \mathrm{~mm}$ and $361 \mathrm{~mm}$. Parnes $(1964$, p. 10) observed in the field specimens of his $C$. zihoricum that had diameters of 700-800 mm. A large phragmocone of C. inflatum Cobban and Hook, n. sp., is $393 \mathrm{~mm}$ in diameter (pl. 14). Lamb (1968, p. 835) recorded specimens of Coilopoceras $455 \mathrm{~mm}$ in diameter from New Mexico.

Hyatt (1903) illustrated only the holotypes of his $C$. colleti and C. novimexicanum and just the suture of his C. springeri. Mention was neither made of variation within each species nor how the species related to one another in time. The lack of other illustrations of these species has led to confusion in the identifications and ages of these species. As an example, Lee (1912, p. 599) recorded $C$. colleti from both the lower and upper parts of the Mancos Shale, whereas the species is really very restricted stratigraphically. At least one of the forms recorded as $C$. colleti by Lee $(1912$, p. 624$)$ is a new species of Hoplitoides, which we are naming $H$. sandovalensis. The present work is an attempt to more precisely define each species, to show something of the intraspecific variation, and to relate the species in time.

At least 27 species of Coilopoceras have been described from various parts of the world. Many of these names are probably synonyms, especially where 
several names have been proposed for specimens from the same locality and stratigraphic position. Many species have been defined largely on small details of the lateral lobe of the suture. Some species have been based on weathered specimens that have poorly preserved sutures. Most species have been illustrated by only one or two specimens, and little or nothing has been noted as to changes with growth as well as variation within the species.

In the present work we have observed considerable variation within the specimens from each locality in New Mexico. In each collection consisting of several specimens or many, some individuals are slender and nearly smooth, whereas others are stouter and more strongly ornamented. Most specimens are within one or the other end of this variation. For example, collections of $C$. colleti Hyatt consist of dominantly stout, well-ribbed specimens with a few slender, nearly smooth individuals, whereas the proportions are reversed in collections of $C$. springeri Hyatt. We are treating these as variable populations of each species, although some authors would probably give separate specific names to the stout form and the slender form.

\section{DISTRIBUTION OF COILOPOCERAS}

Coilopoceras has been recorded from many parts of the world, all in or close to the Tethyan belt. The best references are as follows: California (Anderson, 1958, p. 249), New Mexico (Hyatt, 1903, p. 91-99), Texas, Adkins, 1931, p. 37, 46-51; Powell, 1965, p. 514-517), Mexico (Jones, 1938, p. 125, 126; Powell, 1965, p. 518-522; González-Arreola, 1977, p. 169-171), Trinidad (Reyment, 1972, p. 364), Venezuela (Hedberg and Sass, 1938, p. 80; Renz, 1959, p. 19, 22, 42), Colombia (Bürgl and Dumit-Tobon, 1954, p. 31, 32; Bürgl, 1957, p. 128, 138), Peru (Brüggen, 1910, p. 733-735; Benavides-Cáceres, 1956 , p. 472-475), Ecuador (J. B. Reeside, Jr., in Wasson and Sinclair, 1927, p. 1270, 1271), Brazil (Magalhães, 1952, p. 12-15; de Oliveira and Brito, 1969, p. 227-231), France (Roman and Mazeran, 1920, p. 28-30), Lebanon (Basse, 1937, p. 188, 189), Israel (Parnes, 1964, p. 5-13; Freund and Raab, 1969, p. 66; Lewy, 1975, p. 36, 38, 42); Algeria (Pervinquière, 1910, p. 72-76), Nigeria (Schneegans, 1943, p. 137; Reyment, 1955b, p. 77; Barber, 1957, p. 55), Angola (Hoppenar, 1958, p. 80), Madagascar (Boule and others, 1907, p. 49, 50; Collignon, 1965a, p. 24, 62-66), India (Dassarma and Sinha, 1975, p. 69-72).

The genus has been recorded from rocks of Cenomanian, Turonian, and Coniacian age, but mostly from the Turonian. The Cenomanian record was based on two Algerian species described by Pervinquière (1910, p. $72-76$, pl. 3 , figs. 11-23; text figs. $35-38$ ) as $C$. africanum and C. haugi. Reyment (1955a, p. 575-579; $1955 \mathrm{~b}, \mathrm{p} .75)$ questioned the generic assignment and suggested that the species were schloenbachiids. The suture of the Algerian species resembles that of true Coilopoceras in the general appearance of the first lateral lobe, but the rest of the external suture has only two or three other lateral lobes in contrast to five or six for $C$. colleti, the type of the genus.

The Conician records are from Peru, Venezuela, Israel, and New Mexico. The northern Peruvian record by Brüggen $(1910$, p. $733-735)$ was not well documented stratigraphically, and later work by Benavides-Cáceres (1956, p. 391, 472-475) in northern Peru revealed Coilopoceras only in the Turonian. In Venezuela Renz (1959, p. 42) recorded Coilopoceras sp. with Paralenticeras leonhardianum (Karsten) in the basal part of the Luna Formation, which he assigned to the Coniacian. The Israel record of Coilopoceras in the Coniacian is questionable. Parnes (1964, p. 5, pl. 1, figs. $8-11$; text figs. 2,3$)$ described the new species $C$. zihoricum from strata that he believed were of early Coniacian age. Later work by Lewy $(1975$, p. 25,30$)$ cast doubt on this assignment. The records of Coilopoceras in the Coniacian of New Mexico (Reyment, 1956, p. 38; Dassarma and Sinha, 1975, p. 72, 123) are unfounded.

In the United States Coilopoceras is almost confined to New Mexico and western Texas. An occasional specimen has been found in southwestern Colorado (Lamb, 1968, p. 832), and a single specimen has been found in central Wyoming. All occurrences are in the middle and upper Turonian. The genus is best documented in New Mexico, where the oldest species, $C$. springeri Hyatt, occurs in the late middle Turonian ammonite zone of Prionocyclus hyatti, and the youngest species, C. inflatum Cobban and Hook, n. sp., occurs in the ammonite zones of Prionocyclus macombi and Scaphites warreni of early late Turonian age.

\section{ORIGIN OF COILOPOCERAS}

Ammonites from three stratigraphic horizons in New Mexico reveal the origin of Coilopoceras from Hoplitoides. The oldest of these ammonites is Hoplitoides cf. $H$. wohltmanni (von Koenen) and $H$. cf. $H$. koeneni Solger, which are represented by a very few specimens from Socorro County. These species occur in the lower part of the Tres Hermanos Sandstone Member of the Mancos Shale as well as in the uppermost part of the underlying Mancos Shale. The specimens have truncated venters (fig. 2) at diameters of as much as $70 \mathrm{~mm}$. These Hoplitoides are from beds that contain Tragodesmoceras socorroense Cobban and Hook, Proplacenticeras pseudoplacenta (Hyatt), 
Spathites rioensis Powell, Watinoceras cobbani Collignon, Mammites depressus Powell, and Collignoniceras woollgari woollgari (Mantell).

The next younger horizon is represented by the new species $H$. sandovalensis, which occurs in limestone concretions in the Mancos Shale in the Rio Puerco valley of southern Sandoval County. This species has an inconspicuous truncated venter that is confined to one or two of the early whorls (fig. 6). The venter of the later whorls is sharp. Hoplitoides sandovalensis is present in 10 collections from six localities. Eight of the collections were made many years ago by $T$. W. Stanton, W. T. Lee, C. B. Hunt, and others. Some of their collections include Spathites puercoensis (Herrick and Johnson), Prionocyclus hyatti (Stanton), and Shuparoceras $\mathrm{sp}$. One of the two collections made by us has only $H$. sandovalensis, and the other has, in addition, a specimen of Shuparoceras. The presence of Spathites puercoensis and Prionocyclus hyatti in the other collections may be a result of collecting from a thicker sequence of rocks.

The youngest horizon is represented by Coilopoceras springeri Hyatt in the Semilla Sandstone Member of the Mancos Shale and equivalent rocks in northern Sandoval County. This species closely resembles Hoplitoides in its general appearance and suture, but it differs in lacking a truncated venter in the early whorls. Ammonites associated with $C$. springeri include Spathites puercoensis (Herrick and Johnson) and Prionocyclus hyatti (Stanton).

Coilopoceras was thus derived from Hoplitoides by a progressive reduction in the extent of venter truncation and finally by its disappearance. There are no differences between the suture and the general appearance of the adult whorls of the youngest species of Hoplitoides and those of the oldest species of Coilopoceras.

\section{Coilopoceras colleti Hyatt}

Plate 1, figures 7, 8; plate 3, figures 1-3; plate 5; plate 6, figures 1-8; plates 7-9; text figures 8-10

1903. Coilopoceras colleti Hyatt, U.S. Geological Survey Monograph 44, p. 91, pl. 10, figs. 5-21; pl. 11, fig. 1.

1903. Coilopoceras novimexicanum Hyatt, U.S. Geological Survey Monograph 44, p. 94, pl. 10, figs. 1-4.

1938. Coilopoceras colleti Hyatt. Roman, Les ammonites jurassiques et crétacées, p. 498, pl. 51, figs. 476, 476a.

1942. Coilopoceras colleti Hyatt. Moreman, Journal of Paleontology, v. 16, no. 2, p. 218.

1953. Coilopoceras colleti Hyatt. Magalhães, Revista Cientifica, v. 4, nos. 1-2, pl. 1, fig. 3 .

1955. Coilopoceras colleti Hyatt. Reyment, Geologiska Föreningens i Stockholm Förhandlingar, v. 77, pt. 4, p. 579, text fig. 1a.
1957. Coilopoceras colleti Hyatt. Wright in R. C. Moore, ed., Treatise on invertebrate paleontology, Part L, Mollusca 4, p. L427, fig. 546 (1a-c).

1958. Coilopoceras colleti Hyatt. Luppov and Drushchitz, Principles of paleontology-handbook for paleontologists and geologists of USSR, v. 6, pl. 64, figs. 5a, b.

1975. Coilopoceras colleti Hyatt. Dassarma and Sinha, Paleontologia Indica, n. ser., v. 42, pl. 12, fig. 6.

Hyatt $(1903$, p. 91) characterized this species as having foldlike costae that are highest on the middle of the flank and widest on the outer part of the flank where they weaken and disappear. Hyatt observed that on most of the outer whorl of the holotype, every other rib began at the umbilicus. Most of Hyatt's description concerns the very early growth stages and the details of the suture. Dimensions of the holotype were given by Hyatt as follows: diameter, $67 \mathrm{~mm}$; umbilicus (of internal mold), $7 \mathrm{~mm}$ on one side and $8 \mathrm{~mm}$ on other; thickness (between costae), $18 \mathrm{~mm}$. The holotype is entirely septate. A rib count was not given by Hyatt, but about 10 ribs are visible on one-half whorl at a diameter of $57 \mathrm{~mm}$ (Hyatt, 1903, pl. 10, fig. 5).

Hyatt described only the types of $C$. colleti and $C$. novimexicanum from Carthage. We have at hand more than 30 specimens of $C$. collet $i$ from this locality, which give a better scope of the species. The specimens consist mostly of internal molds of very fine grained sandstone and only small patches of shell material. Most are undistorted, and broken specimens reveal wellpreserved inner whorls (pl. 5, figs. 1-6, 11, 12). The specimens came from a sandstone unit about 18-24 m below the top of the Tres Hermanos Sandstone Member of the Mancos Shale.

Hyatt (1903, pl. 11, fig. 1) presented a very good cross-sectional drawing of the holotype of $C$. colleti, which shows a progressive change in whorl section from broader than high at first to higher than wide later, and changes in the venter from broadly rounded to well rounded to ogival and finally to sharp. In the collections at hand from Carthage, the smallest whorl observed is $7 \mathrm{~mm}$ in diameter. The venter is sharp at this diameter and the lateral ribs are clearly discernible. The innermost visible whorl of another specimen (pl. 5, fig. 13) has a sharp venter at a diameter of $14 \mathrm{~mm}$ and clearly discernible ribs.

The specimens from Carthage grade from slender, weakly ribbed forms to moderately stout, strongly ribbed forms. The whorl section and ornamentation of the holotype of $C$. colleti is representative of the stout form. The slender forms are a little more involute (umbilical ration average of 0.07 ) than the stouter forms (average 0.08). Inasmuch as $C$. colleti from Carthage is the type for the genus, we are presenting in table 2 the dimensions and ratios to the diameter of most measur- 
able specimens of Coilopoceras at hand from the Carthage area (fig. 1, locs. 49-53).

Five adults from the Carthage area have diameters from 279 to $328 \mathrm{~mm}$. Each has part or most of the body chamber. The species, however, attained still larger sizes. A septate specimen consisting of a fourth of a whorl (unfigured hypotype USNM 275895) has a whorl height of $180 \mathrm{~mm}$.

Ribs on juveniles are rectiradiate, straight to slightly sinuous, and divisible into primaries and secondaries. Primaries begin at or near the umbilical shoulder, and secondaries arise about midflank. One or two secondaries separate the primaries. On small specimens less than $40 \mathrm{~mm}$ in diameter, primary ribs arise from low umbilical bullae. As the whorls enlarge, the bullae move progressively outward on the flank, which results in the primaries becoming bullate on the inner one third of the flank on juveniles of about $50 \mathrm{~mm}$ diameter. On the smaller juveniles, all ribs become accentuated a little at the ventrolateral shoulder (pl. 5, figs. $2,3,5,6)$, which gives rise to an ogival whorl section (pl. 6, figs. 1, 3, text fig. 8). The primary and secondary ribs of juveniles typically weaken and flatten on the outer part of the flank before rising into the low ventrolateral swellings. As the whorls enlarge, the primary ribs become higher and broader and form foldlike swellings at midflank, and the ventrolateral swellings may rise into circular, rounded tubercles (fig. 9). Secondary ribs disappear on the last adult septate whorl, where their position is indicated by low ventrolateral tubercles. The ventrolateral tubercles continue onto the adult body chamber and finally weaken and merge into a well-defined, rounded ventrolateral shoulder. The elongate lateral swellings also persist onto the adult body chamber, where they usually number four per one-half whorl. These swellings are as broad as the interspaces.

Primary ribs do not vary much in number on the specimens from the Carthage area. Rib counts on onehalf whorl for 20 specimens average 5.1 and range from 3 to 7, of which the lower numbers tend to be for the larger specimens. Ventrolateral swellings or tubercles average 11 per one-half whorl and range from 9 to 15 .

Hyatt $(1903$, pl. 10, figs. 7,8$)$ illustrated the complete suture of the holotype of $C$. colleti. The external sutures of a stout form and a slender form from the Carthage area are presented herein (fig. 10). These closely resemble each other and differ from that of the holotype only in being a little more dissected. The lateral lobe is almost symmetrically bifid, and its two branches tend to be bifid. The suture of the holotype of C. novimexicanum Hyatt is most unusual and cannot
TABLE 2.-Dimensions and ratios of Coilopoceras colleti Hyatt, Carthage area

[Leaders (...), no measurement]

\begin{tabular}{|c|c|c|c|}
\hline USNM No. & $\begin{array}{l}\text { Diameter } \\
\text { (mm) }\end{array}$ & $\begin{array}{l}\text { Umbilical width } \\
(\mathrm{mm}) \text { and ratio }\end{array}$ & $\begin{array}{l}\text { Thickness (mm) } \\
\text { and ratio }\end{array}$ \\
\hline $\begin{array}{l}275888 \\
278083 \\
275889 \\
275896 \\
278084\end{array}$ & 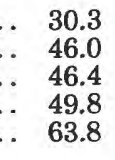 & $\begin{array}{l}2.2(0.07) \\
5.9(0.13) \\
4.1(0.09) \\
4.9(0.10) \\
3.4(0.05)\end{array}$ & $\begin{array}{r}7.9(0.26) \\
13.7(0.30) \\
12.2(0.26) \\
14.5(0.29) \\
17.2(0.27)\end{array}$ \\
\hline $\begin{array}{l}278085 \\
278086 \\
278087 \\
278088 \\
278089\end{array}$ & $\begin{array}{r}64.7 \\
. \quad 65.9 \\
. \quad 84.6 \\
. \quad 89.2 \\
. \quad 91.4\end{array}$ & $\begin{array}{l}8.0(0.12) \\
6.0(0.09) \\
5.5(0.07) \\
5.6(0.07) \\
4.6(0.05)\end{array}$ & $\begin{array}{l}19.7(0.30) \\
18.7(0.28) \\
22.2(0.26) \\
22.4(0.27) \\
25.3(0.28)\end{array}$ \\
\hline $\begin{array}{l}278090 \\
278091 \\
275897 \\
275894 \\
278092\end{array}$ & $\begin{array}{rr} & 96.5 \\
. & 104.0 \\
. & 104.3 \\
. & 117.8 \\
. & 120.8\end{array}$ & $\begin{array}{r}7.8(0.08) \\
7.1(0.07) \\
11.5(0.11) \\
10.4(0.09) \\
6.6(0.05)\end{array}$ & $\begin{array}{l}24.0(0.25) \\
28.5(0.27) \\
34.8(0.33) \\
35.8(0.30) \\
34.5(0.29)\end{array}$ \\
\hline $\begin{array}{l}275899 \\
278093 \\
278094 \\
278095 \\
278096 \\
275904\end{array}$ & $\begin{array}{r}123.5 \\
. \quad 128.5 \\
\text {. } 191.5 \\
. \quad 255.5 \\
. \quad 284.5 \\
. \quad 322.0\end{array}$ & $\begin{array}{r}10.1(0.08) \\
6.7(0.05) \\
16.8(0.09) \\
16.0(0.06) \\
24.0(0.08) \\
34.4(0.11)\end{array}$ & $\begin{array}{c}33.0(0.27) \\
32.0(0.25) \\
56.0(0.29) \\
\overline{-} \\
111.0(0.34)\end{array}$ \\
\hline
\end{tabular}

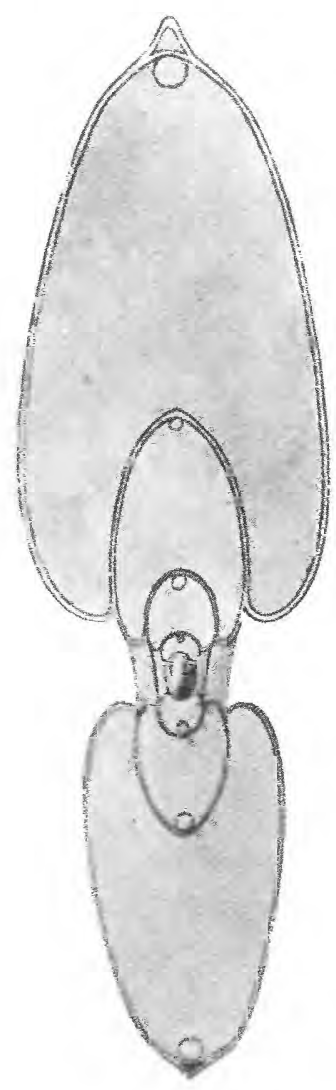

FIGURE 8.-Cross section of the holotype of Coilopoceras colleti Hyatt from Carthage, N. Mex. (from Hyatt, 1903, pl. 11, fig. 1). 
be matched by our material from the Carthage area. Hyatt's drawing of the external suture shows very
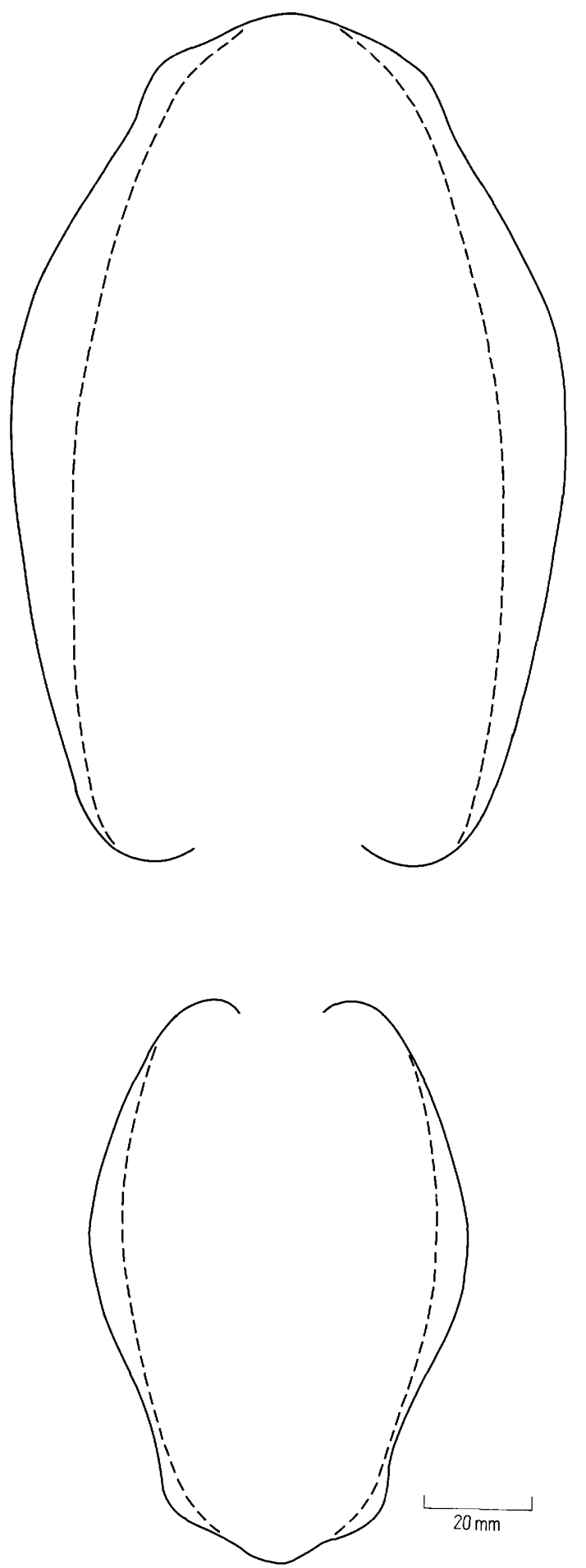

Figure 9.-Cross section through the outer whorl of a large adult Coilopoceras colleti Hyatt at a diameter of $292 \mathrm{~mm}$. Hypotype USNM 275904 (pls. 8, 9) from USGS Mesozoic locality D10354 (fig. 1, loc. 51). Dashed lines are intercostal section. long lobes having numerous branches. The ventrad branch of the first lateral lobe is deeply bifid and its ventrad branch is greatly elongated and digitated so much so that it resembles an independent lobe. Possibly the holotype of $C$. novimexicanum represents the slender form of $C$. colleti that has an aberrant suture.

Aside from the Carthage collections, the only sizeable collection of $C$. colleti at hand consists of 21 specimens from a limestone concretion found northeast of Llaves at USGS Mesozoic locality D4395 (fig. 1 , loc. 4). None of the specimens is an adult, and most are phragmocones. The largest diameter that could be measured is $119 \mathrm{~mm}$. These specimens, like those from the Carthage area, range from slender and nearly smooth (pl. 7, figs. 3-6) to moderately robust and well ribbed (pl. 7, figs. 7-9). Umbilical ratios are from 0.06 to 0.13 , averaging 0.09 , and thickness ratios are from 0.25 to 0.35 , averaging 0.28 . Rib counts for one-half whorl are 4 to 7 primaries, averaging 5.4 , and 9 to 16 secondaries, averaging 11 .

Coilopoceras novimexicanum was described by Hyatt (1903, p. 94, pl. 10, figs. 1-4) from the same locality as $C$. colleti. A rib count was not given, but the number visible in the lateral view (Hyatt, 1903, pl. 10, fig. 1) appears comparable to that of the holotype of $C$. colleti. Most of Hyatt's description concerns the details of the suture which contrast greatly to that of the holotype of $C$. colleti in having longer and narrower lobes with more numerous and longer branches.

Outside the Carthage and Llaves areas, Coilopoceras colleti is represented by very few specimens. A single specimen each from USGS Mesozoic localities D4016 and D10622 (fig. 1, locs. 12, 33) seem well assigned to C. colleti. A few other specimens from USGS Mesozoic localities D3702 and D3883 (fig. 1, locs. 14, 9) may represent this species.

The only ammonite associated with $C$. colleti in the Carthage area is Prionocyclus, which is represented chiefly by large specimens or by fragments of large adults. This Prionocyclus possibly represents large adults of $P$. macombi Meek. The concretion that contained $C$. colleti in the Llaves area also yielded many specimens of $P$. macombi.

Outside the Western Interior region, $C$. colleti has been recorded from Mexico (González-Arreola, 1977, p. 170 , fig. $2 b, c)$. The figured Mexican specimen is a large septate fragment of a robust individual that has strong, broad, foldlike ribs and a $C$. colleti-like suture. The specimen seems too inflated for $C$. colleti and may represent the new species $C$. inflatum Cobban and Hook. Specimens identified as Coilopoceras aff. colleti 


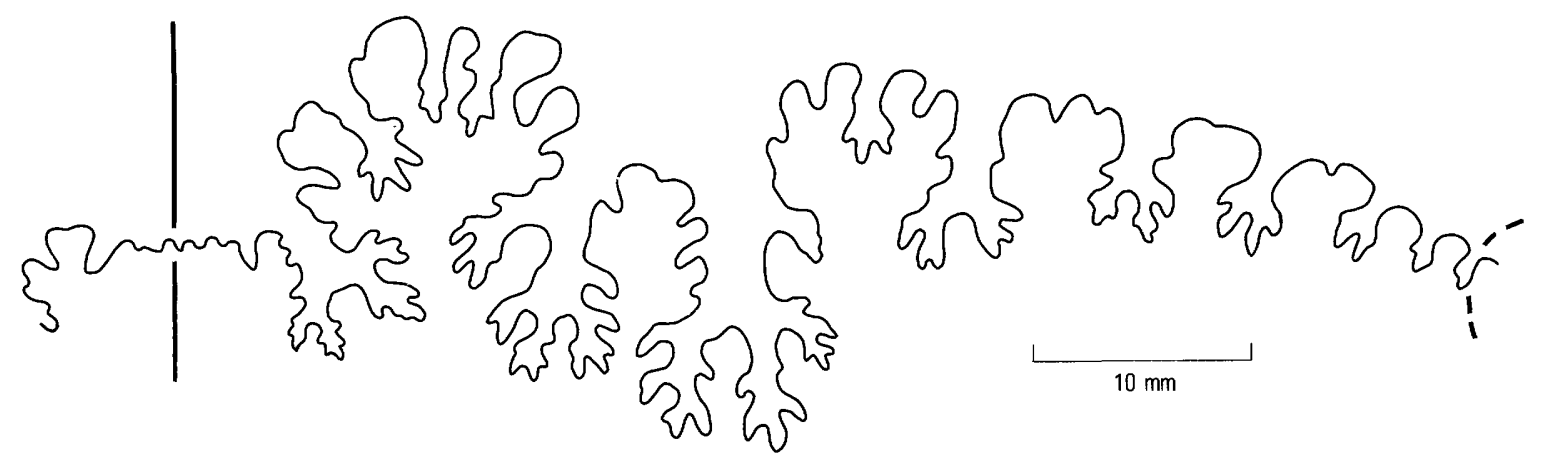

A

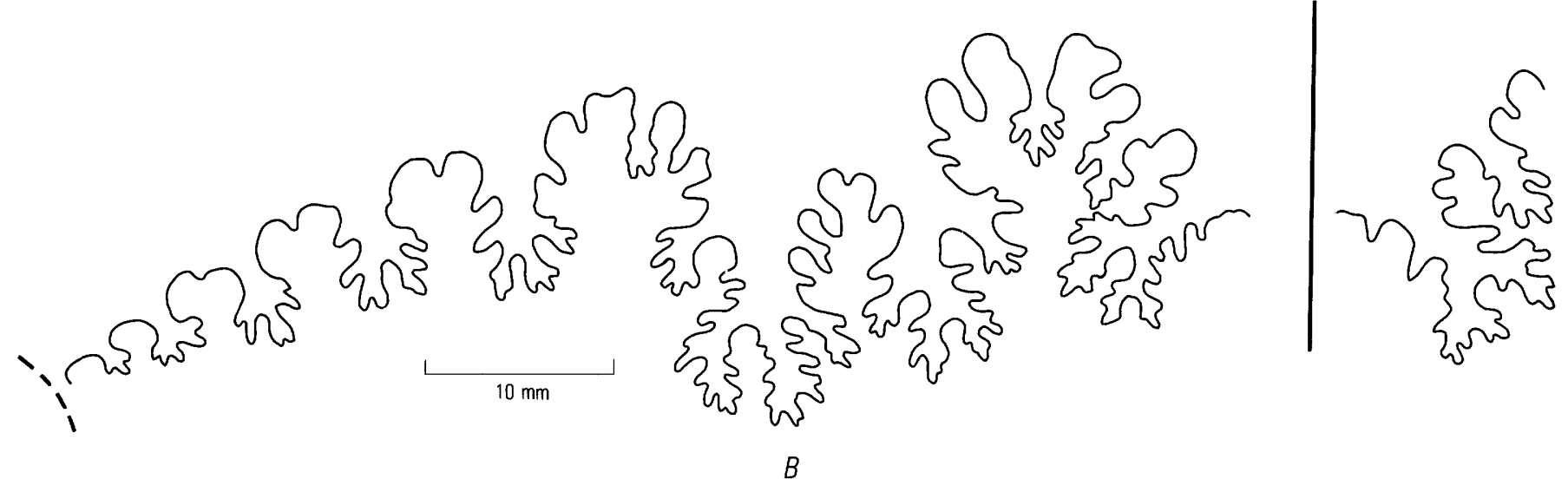

FiguRE 10.-Sutures of Coilopoceras colleti Hyatt from the Carthage area. A, Hypotype USNM 257894 (pl. 5, figs. 14, 15). B, Hypotype USNM 275899.

have been recorded from Colombia (Bürgl, 1957, p. 138) and Nigeria (Reyment, 1955b, p. 77, fig. 37b).

Types.-Hypotypes USNM 275886-275904, 278083-278096.

\section{Coilopoceras springeri Hyatt}

Plate 1, figures 5, 6; plate 3, figures 9-11; plate 6, figures 9, 10; plate 10 ; plate 18 , figures $7-10$; plate 19 , figures $1-9$; text figures $11-13$

1903. Coilopoceras springeri Hyatt, U.S. Geological Survey Monograph 44, p. 96, pl. 12, figs. 1-3.

1931. Coilopoceras eaglefordense Adkins, University of Texas Bulletin 3101, p. 46, pl. 4, figs. 4, 8; pl. 5, fig. 1 .

1931. Coilopoceras chispaense Adkins, University of Texas Bulletin 3101 , p. 48, pl. 4, figs. 5, 7; pl. 5, fig. 2.

1976 [1978]. Glebsoceras (sic) chispaense (Adkins). Young and Powell, Annales du Museum d'Histoire Naturelle de Nice, v. 4, pl. 4, fig. 2; pl. 5, fig. 6.

1976 [1978]. Coilopoceras eaglefordense Adkins. Young and Powell, Annales du Museum d'Histoire Naturelle de Nice, v. 4 , pl. 5 , figs. 4,5 .
Only the suture of the holotype was illustrated. Hyatt described the type as a smooth shell $400 \mathrm{~mm}$ in diameter that consists largely of a phragmocone and a small part of the body chamber. Most of Hyatt's description concerns the details of the suture. The suture differs from that of $C$. colleti in having the first saddle in the lateral lobe of Douville's scheme (Douville, 1911, fig. 37) as high as the middle (Douville's 2) saddle, the third saddle relatively high, and by the addition of an adventive lobe. The overall appearance of the lateral lobe is one having five fairly long branches (fig. 11C). This type of lateral lobe is present in a few other species, such as $C$. indiduraense Jones (1938, pl. 11, fig. 11), C. duartei Oliveira and Brito (1969, text fig. 11), and C. n. sp. B. (J. B. Reeside, $\mathrm{Jr}$., in Wasson and Sinclair, 1927, pl. 9, fig. 3).

The holotype was said to have come from Rit du 
Plain, Colfax County, (fig. 1), which is Rio del Plano on present topographic maps, such as the Abbott NW and Sauble Circle Dot Ranch 71/2-minute quadrangles. The Carlile Shale of Turonian age, which forms the bedrock along much of this drainage (Dane and Bachman, 1965), is the logical source of the specimen. Recently, Hook examined the outcrops along Rio del Plano (fig. 1, loc. 59) and found three specimens of $C$. springeri in very large, septarian, silty limestone concretions in the upper part of a shale unit equivalent to the Blue Hill Member of the Carlile Shale of areas farther north and northeast. A second collection of $C$. springeri (five specimens) was made from the same unit of concretions along the banks of the Canadian River $23 \mathrm{~km}$ farther southwest (fig. 1, loc. 60).

The eight specimens of $C$. springeri from the Rio del Plano and Canadian River localities are moderate to large size. Six of the eight specimens are slender and smooth, whereas the others are a little stouter and have low, foldlike, straight, rectiradiate, primary ribs that are strongest on the lower one-half of the flank (pl. 6, figs. 9, 10). Ribs per one-half whorl number four and six for the two ornamented specimens. None of the specimens has a suture comparable to that of the holotype in having an adventive lobule on the lateral lobe; instead the lateral lobe is like those shown in figure $11(A, B)$.

Very few other fossils were associated with $C$. springeri in the concretions along the Rio del Plano and Canadian River. These fossils include two specimens of Prionocyclus hyatti (Stanton), two specimens of Proplacenticeras pseudoplacenta (Hyatt), and three fragments of large Shuparoceras.

Specimens that we believe are $C$. springeri occur in the Mancos Shale at several localities along the southeastern margin of the San Juan Basin (fig. 1, locs. 4-7, 10-13, 15-17, 21, 23). One of the largest and best preserved collections, from USGS Mesozoic locality D3670 (fig. 1, loc. 7), consists of fragments of 28 phragmocones 70 to $190 \mathrm{~mm}$ in diameter. These specimens, which retain some of their nacreous shell material, came from septarian limestone concretions in a dark-gray shale unit in the Mancos Shale. Preservation of the sutures is excellent (fig. $11 B, C$ ). Most of the specimens have slender whorl sections and smooth or nearly smooth shells (pl. 3, figs. 9-11). Under oblique lighting, faint ribs are discernible on the outer one-half of the flank of most specimens. These ribs are slightly flexuous and attain their greatest height about twothirds of the distance from the umbilicus to the venter. Although most of the specimens are slender, a few fragments of inflated individuals are present. Several broken specimens reveal the whorl sections. The venter changes from well rounded on the very early whorls to lanceolate (fig. 12). These specimens were associated with Prionocyclus hyatti (Stanton).

Specimens that seem assignable to Coilopoceras springeri occur in moderate abundance in the basal part of the Semilla Sandstone Member of the Mancos Shale at its type section in the southwestern part of the San Juan Basin (Dane and others, 1968, p. F19). Twenty-six specimens from three collections (fig. 1, locs. 10, 11, 13) at this locality are suitable for measurements of dimensions (table 3). Inasmuch as these specimens are chiefly internal molds, all dimensions are of internal molds only. These specimens differ a little from those of locality D3670 in having more pronounced ribbing. An occasional well-ribbed individual may have umbilical bullae (pl. 18, figs. 7,8 ) and in this respect are closely similar to $C$. colleti. Perhaps the Semilla specimens occupy an intermediate position in age between that of locality D3670 and that of typical $C$. colleti.

The specimens from the Semilla Sandstone Member were associated with Prionocyclus hyatti (Stanton) and Inoceramus howelli White as well as many other bivalves and a few gastropods (Dane and others, 1968, p. F17-F19). In addition, a few collections from the Mancos Shale include Spathites puercoensis (Herrick and Johnson) (fig. 1, locs. 15, 21, 23), Proplacenticeras pseudoplacenta (Hyatt) (fig. 1, loc. 21), and Shuparoceras (fig. 1, loc. 7).

The specimens from Chispa Summit, Jeff Davis County, Texas, described by Adkins (1931, p. 46-49, pl. 4, figs. 4, 5, 7, 8; pl. 5, figs. 1,2 ) as the new species $C$. eaglefordense and $C$. chispaense, represent the smooth and ribbed forms of $C$. springeri. The sutures illustrated by Adkins are comparable to those of the topotypes of $C$. springeri collected by Hook on the Rio del Plano. We visited the type locality of Adkin's species and collected 10 specimens, of which 7 are smooth and 3 have broad, foldlike primary ribs. Most have sutures like those on specimens from the Rio del Plano-Canadian River area as well as those from the Rio Puerco area, but two have five branches of the lateral lobe as in the suture of the holotype of $C$. springeri. One of these sutures is shown in figure 13.

The specimens at the type locality of Adkins' species were associated with Prionocyclus hyatti (Stanton) as indicated by Powell $(1965$, p. 516, 517). In a later paper, however, Young and Powell (1976, p. 25.15-25.23) show $P$. hyatti as a zone above a zone of Coilopoceras eaglefordense [C. springeri]. We found $P$. hyatti associated with the smooth and ornamented 

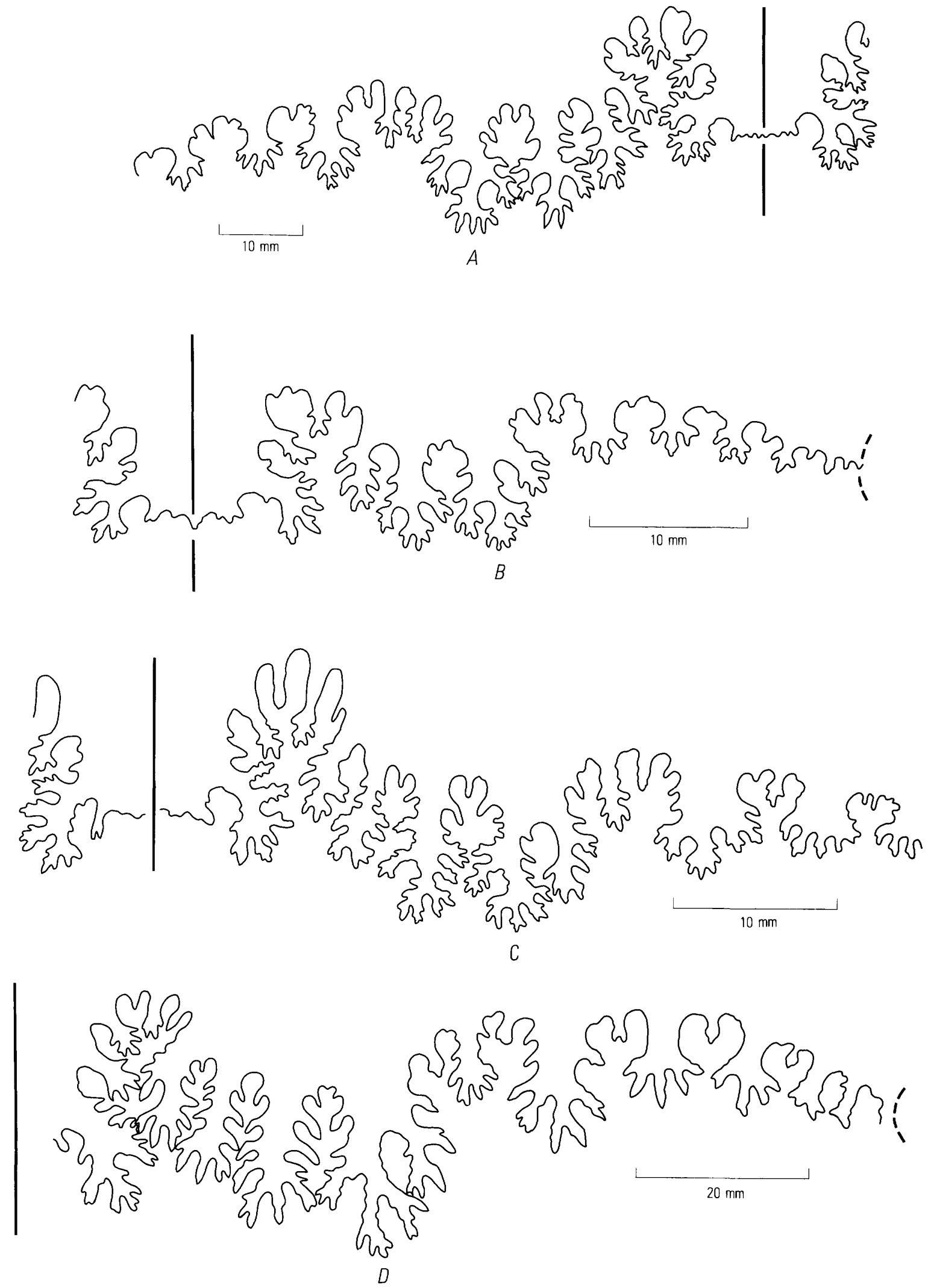


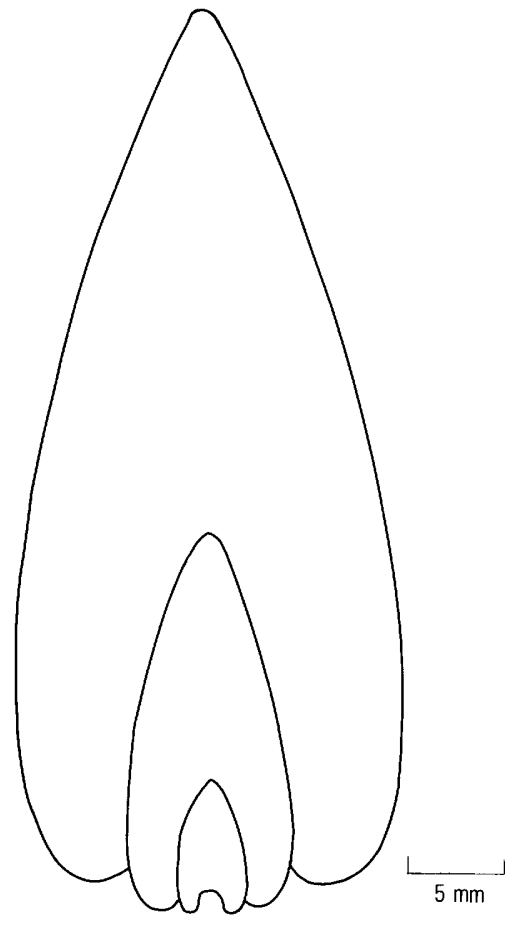

FigURE 12.-Whorl sections of a septate fragment of Coilopoceras springeri Hyatt from USGS Mesozoic locality D3670 (fig. 1, loc. 7). Hypotype USNM 275919.

forms of $C$. springeri at Adkins' locality. Shuparoceras was also found with these.

Types.-Hypotypes USNM 275906-275919, 278101-278123.

\section{Coilopoceras inflatum Cobban and Hook, n. sp.}

Plate 1, figures 9-11; plate 11 , figure 2; plates $12-17$; plate 18 , figures 1-3,11-13; plates 20,21 ; text figures 14,15

We interpret this species as consisting of a dimorphic pair. Most specimens are inflated and conspicuously ribbed. The others are almost smooth and have slender whorl sections. The species was derived from $C$. colleti through changes in the stout form. The stout form of $C$. inflatum tends to be more inflated, the venter is sharper, and the ventrolateral tubercles are lost at a smaller diameter.

The holotype (pl. 11, fig. 2) is part of a large

Figure 11.-External sutures of Coilopoceras springeri Hyatt. $A$, Hypotype USNM 275916 at a whorl height of $75 \mathrm{~mm}$, from USGS Mesozoic locality D3670 (fig. 1, loc. 7). B, Hypotype USNM 275907 (pl. 3, figs. 9-11) at a whorl height of $36 \mathrm{~mm}$, from USGS Mesozoic locality D3670 (fig. 1, loc. 7). $C$, Hypotype USNM 275917 at a whorl height of $50 \mathrm{~mm}$, from the same locality as $A$ and $B . D$, Hypotype USNM 275918 at a whorl height of $92 \mathrm{~mm}$, from USGS Mesozoic locality 28873 (fig. 1, loc. 13).

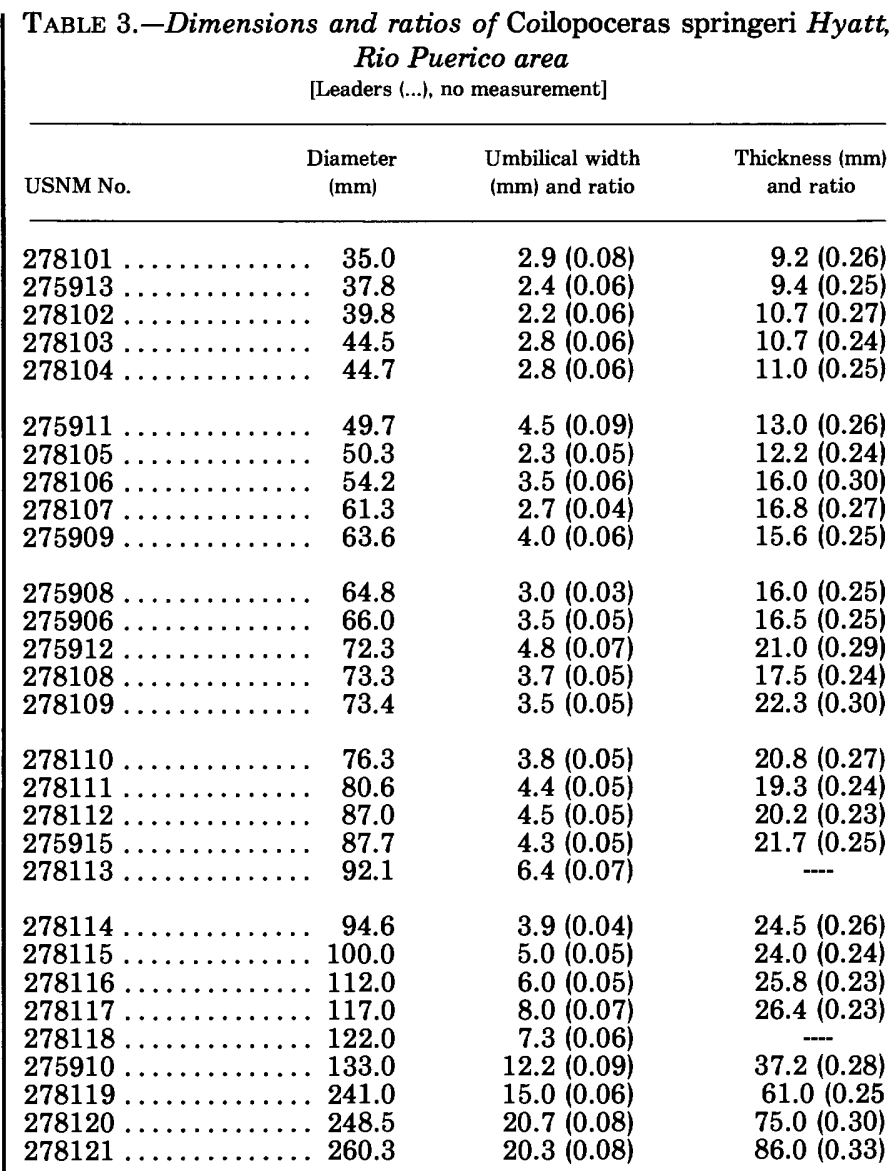

phragmocone of the stout form that exposes two of the inner whorls. A little less than one-half of the outer whorl is preserved; its umbilical width is $24 \mathrm{~mm}$ and its diameter (restored) is estimated at about $258 \mathrm{~mm}$, which would give an umbilical ratio of about 0.09 . The maximum costal whorl thickness is $101 \mathrm{~mm}$ (ratio 0.39). About one-fourth of the innermost whorl is visible, and its diameter is estimated at about $60 \mathrm{~mm}$. The early part of this whorl closely resembles similar-size whorls of the stout form of $C$. colleti in having an ogival section, prominant rectiradiate primary ribs arising from umbilical bullae, primary ribs separated by a secondary one, and all ribs terminating in nodelike ventrolateral swellings. The main difference is in the more robust whorl section of $C$. inflatum. The next whorl has a diameter of about $130 \mathrm{~mm}$ and a costal whorl thickness of $51.3 \mathrm{~mm}$. Ventrolateral swellings are present on the older part of this whorl, where they number about 10 per one-half whorl. These swellings weaken and disappear on the younger part. The outer whorl has only broad, radial swellings crossing much of the flank.

Whorl sections of three stout paratypes are shown in figure 14. Differences between these sections and those 


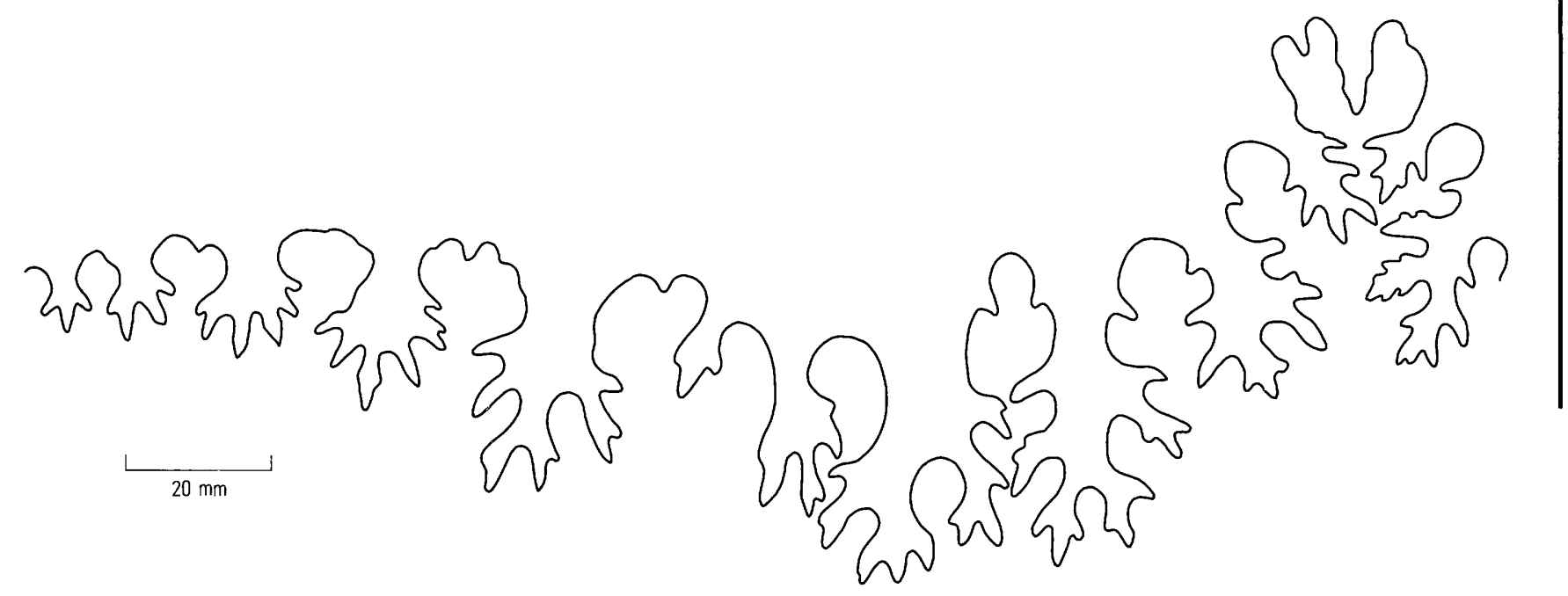

FIGURE 13.-Most of the external suture of a hypotype (USNM 278123) of Coilopoceras springeri Hyatt at a whorl height of 203 mm. From the Chispa Summit Formation at the type locality of C. eaglefordense Adkins and C. chispaense Adkins (Adkins, 1931, fig. 7, loc. 2627) (USGS Mesozoic loc. D10753).

of $C$. colleti (Hyatt, 1903, pl. 10, fig. 6) (text fig. 9) are readily apparent. Whorl sections of $C$. inflatum reveal changes from a well-rounded venter to one that is fastigate, then sharply lanceolate, and finally broadly lanceolate.

The holotype is one of six specimens of Coilopoceras from the basal $3 \mathrm{~m}$ of the D-Cross Tongue of the Mancos Shale at USGS Mesozoic locality D2055 at Cebollita Mesa in southern Valencia County, N. Mex. (fig. 1, loc. 40). Four of the specimens collected with the holotype are inflated and have 4 to 7 primary ribs per one-half whorl and 13 to 15 secondary ones. The dimensions of these inflated specimens and the holotype are given in table 4. The sixth specimen (unfigured paratype USNM 278099), less than one-half whorl of a phragmocone, differs from the others in having a slender whorl section and an almost smooth shell. this individual is interpreted as the compressed, nearly smooth member of the dimorphic species pair.

In the D Cross Mountain area, about $30 \mathrm{~km}$ southeast of Cebollita Mesa, $C$. inflatum also occurs in the basal part of the D-Cross Tongue of the Mancos Shale. A collection, from USGS Mesozoic locality D7066 (fig. 1, loc. 42), consists of five specimens of Coilopoceras 98 to $197 \mathrm{~mm}$ in diameter that have umbilical ratios of 0.08 and 0.09 and thickness ratios of 0.29 to 0.40 . Four of the specimens are readily referable to the inflated form of $C$. inflatum in their robust form and disappearance of ventrolateral swellings on the larger whorls. The fifth specimen (pl. 16, fig. 3), however, is slender and very weakly ribbed, and has the smallest umbilicus (ratio 0.29); it is assigned to the slender, rather smooth member of the dimorphic species pair. One of the other specimens (pl. 17) is unusual in having as many as five secondary ribs separating the primaries on the younger part of the phragmocone. An occasional specimen from other localities has as many as three secondaries between primaries (pl. 15). These more densely ribbed individuals recall $C$. multicostatum Lewy $(1975$, p. 42 , pl. 1, figs. 1, 2, text figs. 15A-D, H) from Sinai and Egypt, which differs in its narrower whorls and simpler suture.

The rarity of the slender, rather smooth form is further emphasized by the presence of a single individual among 11 specimens of $C$. inflatum from another locality in the D Cross Mountain area (D10638, fig. 1, loc. 41). This specimen (unfigured paratype USNM 278100 ), a phragmocone $280 \mathrm{~mm}$ in diameter, has an umbilical ratio of 0.06 and a whorl-thickness ratio of 0.31 .

Collections of $C$. inflatum from the Oscura area in Lincoln County (fig. 1 , locs. 54, 55) have entirely different ratios of the slender, fairly smooth form to the

FIGURE 14.-Whorl sections of the stout form of Coilopoceras inflatum Cobban and Hook, n. sp. A, Paratype USNM 275922 (pl. 12; pl. 13, fig. 2) at a diameter of $258 \mathrm{~mm}$, from USGS Mesozoic locality D10321 (fig. 1, loc. 38). B, Paratype USNM 275938 at a diameter of $102 \mathrm{~mm}$, from USGS Mesozoic locality D2055 (fig. 1, loc. 40). C, Paratype USNM 275923 (pl. 14) at a whorl height of $202 \mathrm{~mm}$, from USGS Mesozoic locality D10634 (fig. 1, loc. 22). Dashed lines are intercostal sections. 

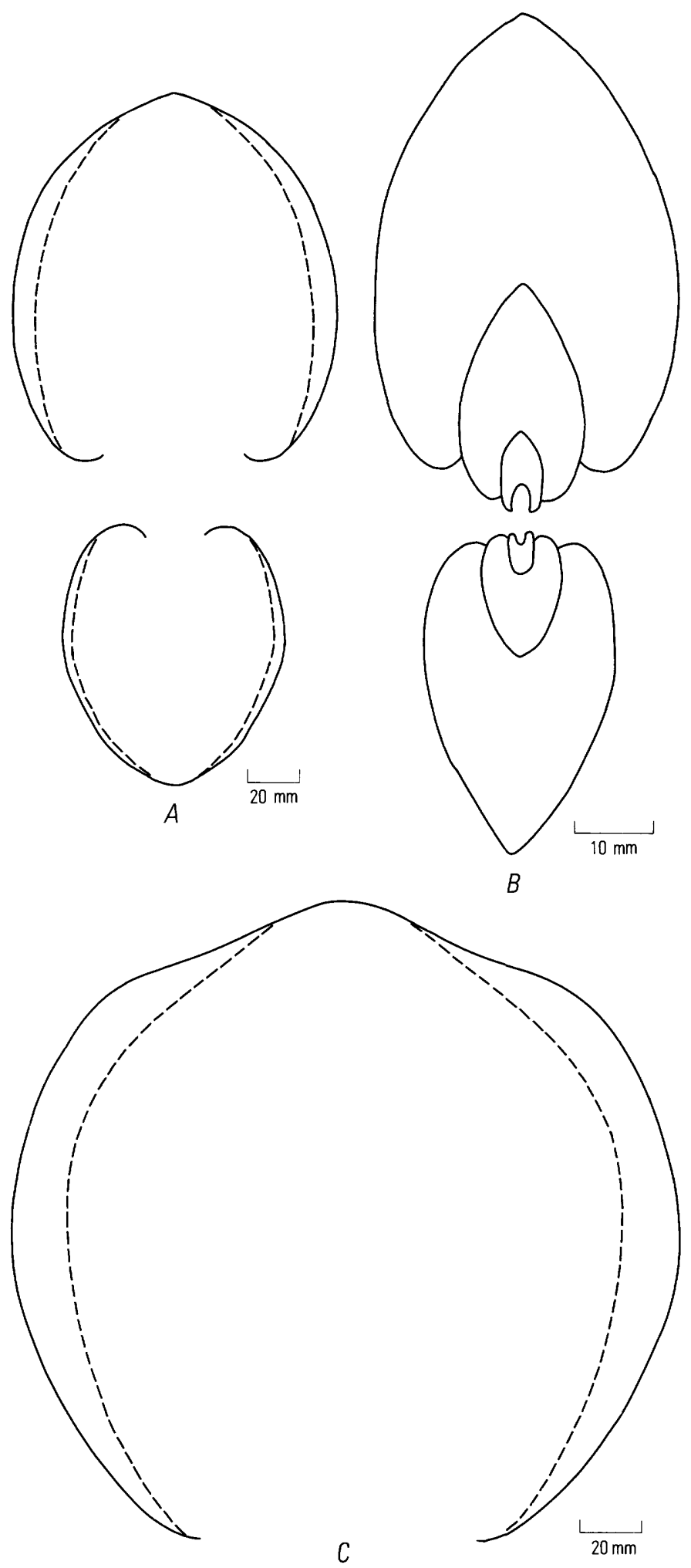

TABLE 4.-Dimensions and ratios of Coilopoceras inflatum Cobban and Hook, n. sp.

\begin{tabular}{|c|c|c|c|}
\hline USNM No. & $\begin{array}{c}\text { Diameter } \\
\text { (mm) }\end{array}$ & $\begin{array}{l}\text { Umbilical width } \\
(\mathrm{mm}) \text { and ratio }\end{array}$ & $\begin{array}{l}\text { Thickness (mm) } \\
\text { and ratio }\end{array}$ \\
\hline $\begin{array}{l}275938 \text {. } \\
278097 \text {. } \\
275921 \text {. }\end{array}$ & $\begin{array}{r}104.0 \\
.106 .5 \\
.124 .5\end{array}$ & $\begin{array}{l}10.2(0.10) \\
11.0(0.10) \\
10.7(0.09)\end{array}$ & $\begin{array}{l}36.5(0.35) \\
37.3(0.35) \\
44.0(0.35)\end{array}$ \\
\hline $\begin{array}{l}278098 \text {. } \\
275920 \text {. }\end{array}$ & $\begin{array}{l}201.5 \\
251.0\end{array}$ & $\begin{array}{l}17.6(0.09) \\
24.0(0.10)\end{array}$ & $\begin{array}{l}76.0(0.38) \\
97.5(0.39)\end{array}$ \\
\hline
\end{tabular}

inflated ornamented form. Two nearby collections (USGS Mesozoic locs. D10636 and D10644) from the same stratigraphic position consist of 17 slender individuals and 26 robust ones. Examples from these localities are shown in plates 20 and 21 .

The largest specimens of $C$. inflatum are extremely robust (pls. 12-14). One huge individual, septate at a diameter of $393 \mathrm{~mm}$, has an extraordinary thickness ratio of 0.54 (pl. 14; text fig. 14C).

The suture of $C$. inflatum is similar to that of $C$. colleti in having the lateral lobe distinctly bifid (fig. 15). An important difference, however, is in the deep bifurcation of the ventral branch of this lobe of $C$. inflatum.

Coilopoceras inflatum closely resembles the very stout fragment from Mexico referred to $C$. colleti by González-Arreola (1977, p. 170, fig. 2b, c). The suture of the Mexican specimen seems to be simpler, and the ventral branch of the first lateral lobe is not as deeply bifid. The only other well-inflated form of Coilopoceras is the Nigerian species $C$. discoideum Barber (1957, p. 55 , pl. 2, fig. 1; pl. 3, figs. 1, 2a, b; pl. 25, figs. 1-4). A lateral view of a paratype (Barber, 1957, pl. 3, fig. 2a) suggests that the inner whorls have ventrolateral swellings much like those of similar-size specimens of C. inflatum. Coilopoceras discoideum differs, however, in its lanceolate inner whorls, instead of fastigate ones and in its smooth adult whorls. Coilopoceras chispaense Adkins (1931, p. 48, pl. 4, figs. 5, 7; pl. 5, fig. 2) is also an inflated form that seems to lack the noded growth stage of $C$. inflatum.

The deep bifurcation of the ventral branch of the lateral lobe is matched by many species of Coilopoceras such as $C$. requienianum (d'Orbigny, 1840, pl. 93, fig. 4), C. haugi Pervinquière (1910, fig. 37), $C$. grossouvrei Hyatt (1903, pl. 12, fig. 7), C. sinaiense Lewy (1975, fig. 15 I-K), C. scindiae (Vredenburg, 1907, pl. 16, fig. 2), C. jenksi and C. newelli (BenavidesCáceres, 1956, figs. 52, 53), and the Brazilian species $C$. lucianoi (Oliveira, 1969, fig. 1) as well as those described by Oliveira and Brito (1969, figs. $9,10,12)$ as $C$. sergipensis, C. brasiliensis, and C. mauryae. 

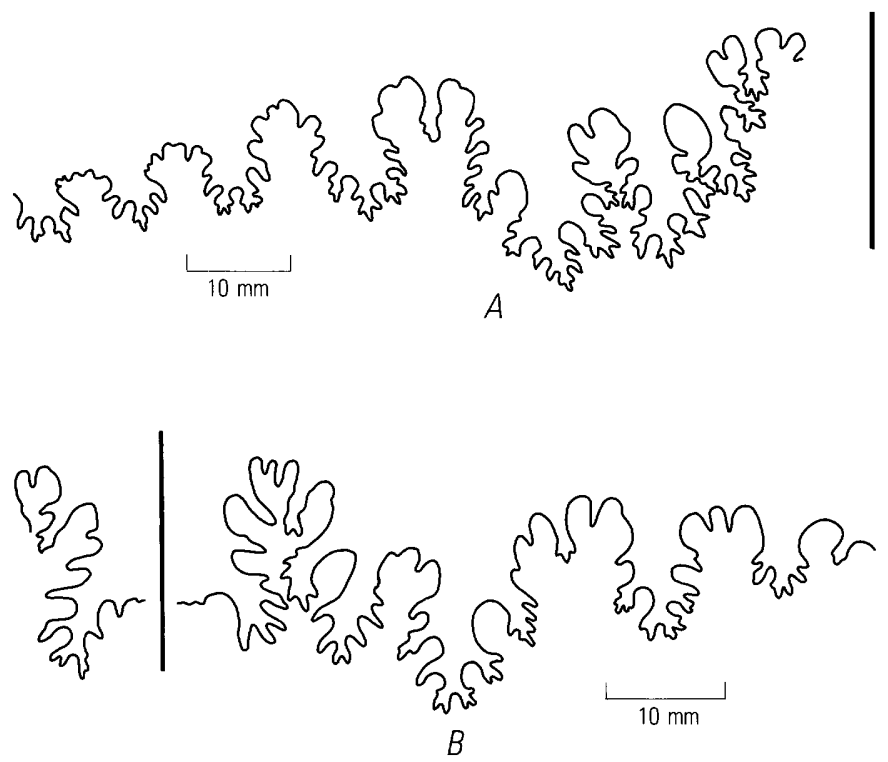

Figure 15.-External sutures of Coilopoceras inflatum Cobban and Hook, n. sp. $A$, Holotype USNM 275920 (pl. 11, fig. 2) at a whorl height of $73 \mathrm{~mm}$, from USGS Mesozoic locality D2055 (fig. 1, loc. 40). B, Paratype USNM 275939 at a whorl height of $65 \mathrm{~mm}$, from USGS Mesozoic locality D10602 (fig. 1, loc. 35). Heavy lines mark middle of venter.

The holotype of $C$. inflatum was associated at USGS Mesozoic locality D2055 (fig. 1, loc. 40) with a few fragments of large Prionocyclus that may be $P$. wyomingensis Meek. A collection (USGS Mesozoic loc. D2056) $5 \mathrm{~m}$ above D2055 contains $P$. wyomingensis Meek, Scaphites warreni Meek and Hayden, and Inoceramus dimidius White.

Types.-Holotype USNM 275920, paratypes, USNM 275921-275939, 278097-278100.

\section{Genus HERRICKICERAS Cobban and Hook, n. gen.}

Type species.-Placenticeras costatum Herrick and Johnson, 1900.

This genus is proposed for involute, compressed ammonites that have on the inner whorls a sulcate venter bounded on each side by a sharp keel bearing clavate tubercles. The external suture has a very broad, deeply bifid first-lateral saddle and a smaller bifid lateral lobe that has the branch nearest the umbilicus in a more lowered position.

The genus is known only from $H$. costatum (Herrick and Johnson) of middle Turonian age. Herrickiceras appeared suddenly in New Mexico in rocks that contain Hoplitoides sandovalensis. Herrickiceras may have had its origin in either Donenriquoceras Wiedmann $(1959$, p. 758 , pl. 7, figs. 1-4; text figs. 13,14 ) or Imlayites (Leanza, 1967, p. 196, pl. 4, figs. 1-4; pl. 6, figs. 1, 4-6), both of early Turonian age. Donenriquoceras, from Spain, resembles Herrickiceras in its compressed form, very small umbilicus, venter bounded by tubercles in the inner whorls, and in the bifid lateral lobe having the branch nearest the umbilicus in a more lowered position; it differs in lacking a sulcate venter bordered by sharp keels and in having a narrower first-lateral saddle. Imlayites, from Colombia, resembles Herrickiceras in its compressed form, very small umbilicus, and sulcate venter; it differs in lacking ventrolateral tubercles, and its suture is simpler and arranged differently.

Herrickiceras is named in honor of Clarence L. Herrick for his pioneer studies of the geology of central New Mexico, including the Rio Puerco valley, the source of most of our Coilopoceratidae. For an excellent biography of Herrick, the reader is referred to Herrick (1955).

\section{Herrickiceras costatum (Herrick and Johnson)} Plate 19, figures 10-18; text figure 16

1900. Placenticeras costata Herrick and Johnson, Bulletin of the Scientific Laboratories of Denison University, v. 11, art. 9, p. 214, pl. 28, figs. 2,3 .

1900. Placenticeras costata Herrick and Johnson, Bulletin of the University of New Mexico, v. 2, p. 40, pl. 2, figs. 2, 3.

1954. "Hoplitoides" cf. "H." munieri Pervinquière. Kummel and Decker, Journal of Paleontology, v. 28, no. 3, p. 317, pl. 33, figs. 1, 2; text figs. 7A, 10.

The holotype, and only specimen described, was destroyed when the Hadley Laboratory at the University of New Mexico in Albuquerque burned May 23, 1910. According to Herrick and Johnson (1900), the type was $95 \mathrm{~mm}$ in diameter and $21 \mathrm{~mm}$ in thickness. Their description of the form and ornamentation is as follows:

Shell lenticular, compressed, of moderate size; umbilicus very small; volutions deeply embracing, widest a little distance from the umbilicus; dorsum flat or slightly channeled, crossed by a continuation of the nodes; surface marked by numerous irregular, subtriangular and curved ribs, the larger ones extending from the dorsum to the umbilicus and separated by one or more short, oblique ribs originating on the dorsum where they give rise to small elongate nodes; aperture apparently narrowly cordate, flaring on either side of the volution embraced by it.

Herrick and Johnson described the outer part of the external saddle and noted that the first-lateral saddle was wider than the lateral lobe. The suture is shown in the lateral view of their drawing of the type (Herrick and Johnson, 1900, pl. 28, fig. 3). The lateral lobe is bifid, and the part nearest the umbilicus is in a more lowered position than the other part. In addition, the umbilical one-half of the lateral lobe is trifid, whereas the ventral one-half is deeply divided into two long, narrow lobules. The first lateral saddle of the external suture is symmetrically divided by a long, narrow lobe.

Herrick and Johnson's drawings show about 16 flexuous ribs per one-half whorl and show that each rib 
crosses the sulcate venter. The ribs are broadest on the outer part of the flank.

An excellent specimen collected by Neal La Fon, of Albuquerque, is selected as a neotype (USNM 275940) to replace the destroyed type. La Fon's specimen, an adult $118 \mathrm{~mm}$ in diameter, has nearly one-half whorl of the body chamber preserved. The phragmocone is uncrushed but is a little distorted. The umbilicus is very small and has a maximum diameter of $4.7 \mathrm{~mm}$ and a ratio of 0.04 of the shell diameter. The umbilical wall is steep, and the umbilical shoulder is narrowly rounded. The shell has a slender cross section with the greatest width near the umbilicus. A thickness ratio of 0.29 percent is indicated for the base of the body chamber at a diameter of $83 \mathrm{~mm}$.

Fifteen sinuous ribs are present on the last one-half of the phragmocone. About every third rib extends to the umbilicus. On the inner one-half of the flank, the longer ribs are straight, rectiradiate, and very weak, but on the outer one-half, each rib becomes stronger, curves backward and then forward and disappears at or near the edge of the venter. Secondary ribs arise at midflank and follow the curvature of the other ribs. The ribs reappear very faintly in the sulcate venter, which they cross at right angles. All ribs weaken at the base of the body chamber and gradually disappear.

The suture (fig. $16 \mathrm{C}$ ) of the neotype very closely resembles that of Herrick and Johnson's type. Parts of the external sutures of two other specimens are also shown in figure 16.

The presence of small elongate tubercules on the edge of the venter was noted by Herrick and Johnson. These are not present on the visible whorl of the neotype. They are clearly visible, however, on a smaller specimen (pl. 19, fig. 10), where they are small, clavate, closely spaced, and alined with the ribs. On the same specimen, but at a larger diameter, the tubercles gradually fuse with one another to form a keel on each edge of the venter.

Herrick and Johnson's type came from a unit of septarian limestone concretions in the Mancos Shale in the Rio Puerco valley in southern Sandoval County. Our specimens are from the same area (fig. 1, locs. 27, 32), where they were associated with Hoplitoides sandovalensis.

The specimen from Cuchillo Parado, Chihuahua, Mexico, figured by Kummel and Decker $(1954$, p. 317, pl. 33, figs. 1, 2; text figs. 7A, 10) as "Hoplitoides" cf. " $H$." munieri Pervinquière is probably Herrickiceras costatum. The Mexican specimen has ribs crossing the sulcate venter, and the first-lateral saddle of the external suture is broader than the lateral lobe.

Types.-Neotype USNM 275940, hypotypes USNM 275941, 275942.
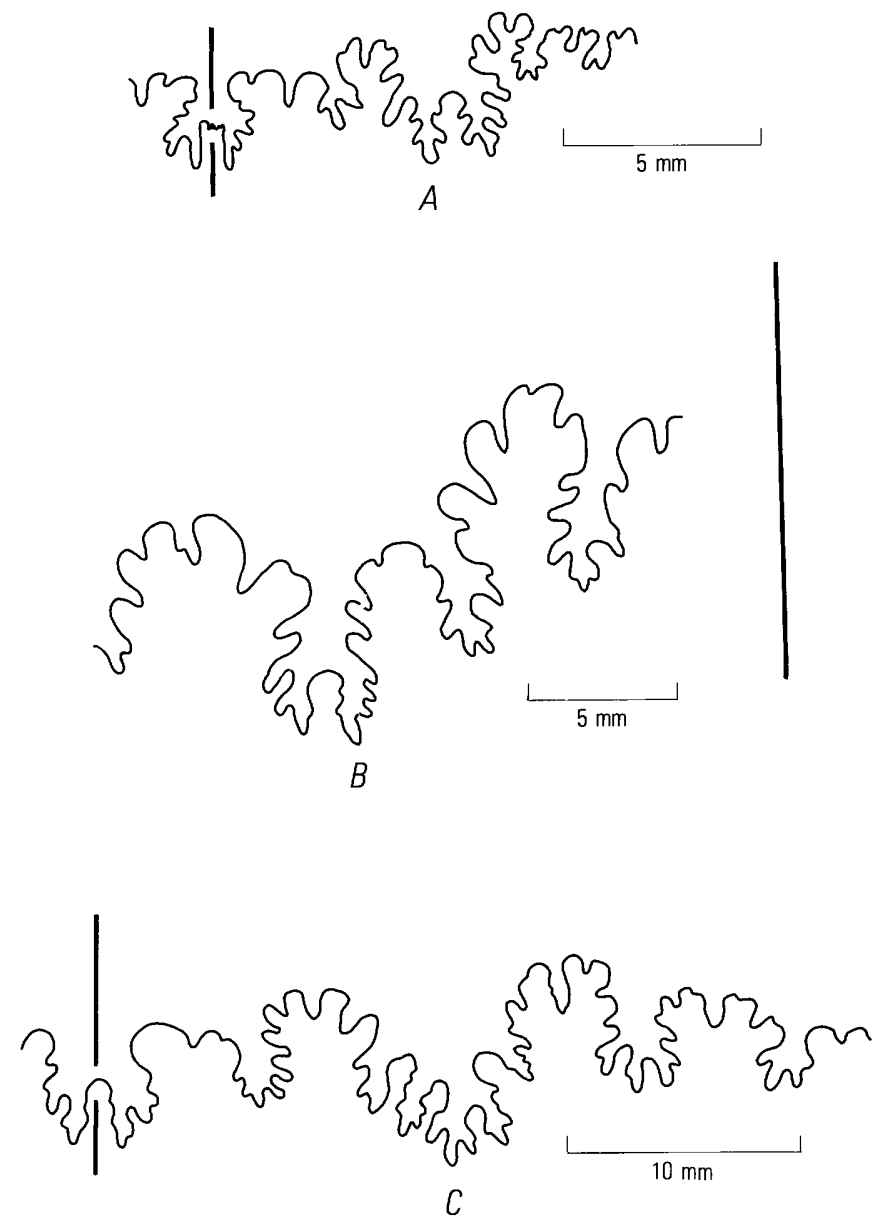

Figure 16.-External sutures of Herrickiceras costatum (Herrick and Johnson). $A$, Hypotype USNM 275941 (pl. 19, figs. 10-12) at a diameter of $32 \mathrm{~mm}$, from USGS Mesozoic locality D10469 (text fig. 1, loc. 32). B, Hypotype USNM 275942 (pl. 19, figs. 13-15) at a diameter of $71 \mathrm{~mm}$, from the same locality. $C$, Neotype USNM 275940 (pl. 19, figs. 16-18) at a whorl height of $33 \mathrm{~mm}$, from USGS Mesozoic locality D10508 (fig. 1, loc. 27). Heavy lines mark middle of venter.

\section{AGE RELATIONSHIPS OF COILOPOCERATIDAE}

Most species of the Coilopoceratidae in New Mexico are known only from local areas and this complicates their age relationships. The general sequence, from oldest to youngest, of Hoplitoides ef. $H$. koeneni, $H$. sandovalensis, Coilopoceras springeri, $C$. colleti, and C. inflatum, seems well established, but local populations within the species of Coilopoceras are somewhat uncertain.

The oldest species, Hoplitoides $\mathrm{cf}$. $H$. koeneni and $H$. cf. $H$. wohltmanni, occur with Collignoniceras woollgari woollgari, which permits a correlation with the zone of $C$. woollgari in Europe. Inasmuch as $C$. woollgari also occurs in west Texas and northern Mexico (as Selwynoceras mexicanum of Powell, 1963, 
p. 1225), a correlation with rocks in these areas is indicated. Watinoceras cobbani Collignon $(1966$, p. 36 , pl. 19 , figs. $8,8 \mathrm{a}, 8 \mathrm{~b}$ ) was collected by us from beds containing C. woollgari woollgari in Socorro County. This species of Watinoceras is found in the Moroccan zone of Benueites benueensis and Watinoceras guentheri of Collignon (1966, p. 67), which suggests an age equivalent to that of the Hoplitoides from New Mexico. Collignon considered this zone as middle Turonian. Among the ammonites from this zone in Morocco is the species Proplacenticeras zaharense Collignon (1966, p. 33, pl. 18, figs. 5-9), which has a sulcate venter and an umbilicus too narrow for Proplacenticeras. The species may well be a Hoplitoides much like the ones from New Mexico.

Hoplitoides sandovalensis and Herrickiceras costatum occur in a very limited area in the Rio Puerco valley. Seven of the 10 collections containing $H$. sandovalensis include specimens of Spathites puercoensis (Herrick and Johnson). A few collections include Prionocyclus hyatti (Stanton) or Shuparoceras. The zone cannot be correlated outside the Rio Puerco area.

The collection of Coilopoceras springeri from the Rio Puerco valley (D3670, fig. 1, loc. 7) that consists dominantly of smooth or nearly smooth specimens resembles Hoplitoides sandovalensis in this respect. Associated fossils include Inoceramus howelli White, Prionocyclus hyatti (Stanton), and a fragment of Shuparoceras. The collection is probably slightly younger than those containing $H$. sandovalensis.

Collections from the Semilla Sandstone Member of the Mancos Shale contain a Coilopoceras referred to $C$. springeri. These specimens have sutures like those from locality D3670, but the shells tend to be more ornamented, foreshadowing $C$. colleti. Associated fossils include Inoceramus howelli and Prionocyclus hyatti.

Coilopoceras colleti from the Carthage area is associated with Prionocyclus macombi Meek and Lopha bellaplicata novimexicana Kauffman. Coilopoceras colleti from the Llaves area (D4395, fig. 1, loc. 3 ) is associated also with $P$. macombi, but the Lopha is absent and its place taken by Inoceramus aff. $I$. dimidius White. Collection D4395 came from $3 \mathrm{~m}$ below the base of beds containing Lopha lugubris (Con$\mathrm{rad})$. The collections from the Carthage and Llaves area may be the same age or, possibly, that from Llaves may be slightly younger.

Coilopoceras inflatum at localities D10636 and D10644 near Oscura (fig. 1, locs. 54, 56) is found with Lopha lugubris, Prionocyclus macombi, and Inoceramus dimidius White. A rare occurrence of the ammonite Hourcquia in this collection may provide a means of international correlation. Hourcquia has been described only from Madagascar (Collignon, 1965a, p.
77-82, pl. 411-413) and Japan (Matsumoto, 1970, p. 310-314, pl. 49, fig. 2a-d, text figs. 4, 5) and possibly France (de Grossouvre, 1893, p. 51, pl. 2, fig. 6a, b). The type of the genus, $H$. mirabilis Collignon, is from the upper Turonian zone of Coilopoceras requieni (d'Orbigny) and Romaniceras deveriai (d'Orbigny) according to Collignon (1965a, p. 78).

The youngest of the Western Interior Coilopoceratidae may be $C$. inflatum in the D Cross Mountain-Cebollita Mesa area (fig. 1, locs. 40-44) where the species is associated with Prionocyclus wyomingensis Meek.

\section{REFERENCES CITED}

Adkins, W. S., 1931, Some Upper Cretaceous ammonites in western Texas: Texas University Bulletin 3101, p. 35-72, pls. 2-5.

Anderson, F. M., 1958, Upper Cretaceous of the Pacific coast: Geological Society of American Memoir 71, 378 p., 75 pls.

Barber, W. M., 1957, Lower Turonian ammonites from north-eastern Nigeria: Nigeria Geological Survey Bulletin 26, 67 p., 34 pls.

Basse, Éliane, 1937, Les céphalopodes crétacés des massifs côtiers syriens, [pt. 1] in Contribution à l'étude géologique de la côte libano-syrienne: Haut-Çommissariat République Française, Syrie et Liban, Section Études Géologique, Notes et Mémoires, v. 2 , p. $165-200$, pls. 8-11.

1940, Les céphalopodes crétacés des massifs côtiers syriens, pt. 2 of Études paléontologiques: Haut-Commissariat République Française, Syrie et Liban, Section Études Géologique, Notes et Mémoires, v. 3, p. 411-471, 9 pls.

1953, Présence des genres Hoplitoides et Coilopoceras dans l'extrême Nord de Madagascar: Cahiers Géologiques de Thoiry, no. 21, p. 188.

Benavides-Cáceres, V. E., 1956, Cretaceous System in northern Peru: Bulletin of the American Museum of Natural History, v. 108 , art. 4, p. 353-494, pls. 31-66.

Böse, Emil, 1918 [1920], On a new ammonite fauna of the lower Turonian of Mexico: Texas University Bulletin 1856, p. 173-252, pls. 12-20.

Boule, Marcellin, Lemoine, Paul, and Thevenin, Armand, 1906-7, Céphalopodes crétacés des environs de Diégo-Suarez [Madagascar]: Annales Paléontologie-1906, v. 1, pt. 4, p. 173-192, pls. $14-20 ; 1907$, v. 2 , pt. 1 , p. $1-56$, pls. 1-8.

Brüggen, Hans, 1910, Die Fauna des unteren Senons von NordPerú: Neues Jahrbuch für Mineralogie, Geologie und Paläontologie, Beilage, v. 30, p. 717-788, pls. 25-29.

Bürgl, Hans, 1957 [1958], Biostratigrafia de la Sabana de Bogota y sus Alrededores: Colombia Instituto Geologico Nacional Boletin Geologia, v. 5, no. 2, p. 113-147, pls. 1-20.

Bürgl, Hans, and Dumit Toban, Yolanda, 1954, El Cretaceo superior en la region de Girardot: Colombia Instituto Geologico Nacional Boletin Geologia, v. 2, no. 1, p. 23-48.

Cobban, W. A., and Hook, S. C., 1979 [1980], Collignoniceras woollgari woollgari (Mantell) ammonite fauna from Upper Cretaceous of Western Interior, United States: New Mexico Bureau of Mines and Mineral Resources Memoir 37, 51 p., $12 \mathrm{pls}$.

Collignon, Maurice, 1965a, Atlas des fossiles caractéristiques de Madagascar (amınonites); Part 12, Turonien: Republique Malgache Service Géologique, Tananarive, 82 p., pls. 376-413. 1965b, Nouvelles ammonites néocrétacées sahariennes: Annales Paléontologie, v. 51, pt. 2, p. 165-202, pls. A-H. 
1966, Les Céphalopodes crétacés du bassin côtier de Tarfaya: Maroc Service Géologique Notes et Mémoires 175, 148 p., 35 pls.

Dane, C. H., and Bachman, G. O., 1965, Geologic map of New Mexico: Washington, D.C., U.S. Geological Survey, 2 sheets, scale 1:500,000.

Dane, C. H., Cobban, W. A., and Kauffman, E. G., 1966, Stratigraphy and regional relationships of a reference section for the Juana Lopez Member, Mancos Shale, in the San Juan Basin, New Mexico: U.S. Geological Survey Bulletin 1224-H, 15 p.

Dane, C. H., Kauffman, E. G., and Cobban, W. A., 1968, Semilla Sandstone, a new member of the Mancos Shale in the southeastern part of the San Juan Basin, New Mexico: U.S. Geological Survey Bulletin 1254-F, 21 p.

Dane, C. H., Wanek, A. A., and Reeside, J. B., Jr., 1957, Reinterpretation of section of Cretaceous rocks in Alamosa Creek valley area, Catron and Socorro Counties, New Mexico: American Association of Petroleum Geologists Bulletin, v. 41, no. 2, p. 181-196.

Dassarma, D. C., and Sinha, N. K., 1975, Marine Cretaceous formations of Narmada Valley (Bagh Beds), Madhya Pradesh and Gujarat: Palaeontologia Indica, n. ser., v. 42, 123 p., 12 pls.

Douvillé, Henri, 1911, Évolution et classification des Pulchelliidés: Bulletin de la Société Géologique de France, 4th ser., v. 11, p. 285-320.

1928, Les ammonites de la Craie supérieure en Égypte et au Sinai: Académie des Sciences de l'Institut de France Mémoires, 2 d ser., v. 60,43 p. 7 pls.

Eck, Otto, 1915, Die Cephalopoden der Schweinfurthschen Sammlung aus der Oberen Kreide Ägyptens: Zeitschrift der Deutschen Geologischen Gesellschaft, v. 66, p. 179-216, pls. 9-19.

Freund, Raphael, and Raab, Menahem, 1969, Lower Turonian ammonites from Israel: Palaeontological Association of London Special Paper 4, 83 p., 10 pls.

Gioffredi, L. B., Monechi, Simonetta, and Pinna, Giovanni, 1976, I fossili Turoniani di Ras-sjaga (Giordania orientale): Societa Italia Scienze Naturali, Natura, v. 67, nos. 1-2, p. 37-46.

Gioffredi, L. B., Monechi, Simonetta, and Pinna, Giovanni, 1976, (Cretacico Superior) de la region de Tepetlapa, Estado de Guerrero: Universidad Nacional Autónoma de México Instituto de Geología, Revista, v. 1, no. 2, p. 167-173.

Grossouvre, Albert de, 1893 [1894], Les ammonites de la craie supérieure, Pt. 2, Paléontologie, of Recherches sur la craie supérieure: La Carte Géologique Détaillée de la France Mémoires, 264 p., 39 pls.

Hedberg, H. D., and Sass, L. C., 1938, Synopsis of the geologic formations of the western part of the Maracaibo Basin, Venezuela: Venezuela Servicio Técnico Mineria y Geologia Boletin, v. 1, nos. 2-4, p. 71-112.

Herrick, C. J., 1955, Clarence Luther Herrick, pioneer naturalist, teacher, and psychobiologist: Transactions of the American Philosophical Society, n.s., v. 45, pt. 1, 83 p.

Herrick, C. L., and Johnson, D. W., 1900, The geology of the Albuquerque sheet: Denison University Bulletin of the Scientific Laboratories, v. 11, art. 9, p. 175-239, pls. 27-32.

Hoppener, H., 1958, Brief report on the paleontology of the Cuanza basin, Angola: Boletim de Sociedade Geológica de Portugal, v. 12 , pt. 3, p. $75-82$.

Hyatt, Alpheus, edited by T. W. Stanton, 1903, Pseudoceratites of the Cretaceous: U.S. Geological Survey Monograph 44, 351 p., 47 pls.

Jones, T. S., 1938, Geology of Sierra de la Peña and paleontology of the Indidura formation, Coahuila, Mexico: Geological Society of America Bulletin, v. 49, no. 1, p. 69-150, pls. 1-13.

Koenen, Adolf von, 1897-98, Ueber Fossilien der unteren Kreide am
Ufer des Mungo in Kamerun: Abhandlungen der Königlichen Gesellschaft der Wissenschaften zu Göttingen, MathematischPhysikalische Klasse, n. ser., 1897, v. 1, no. 1, p. 1-48, pls. 1-4; 1898 , v. 1 , no. 1 , p. 49-65, pls. 5-7.

Kummel, Bernhard, and Decker, J. M., 1954, Lower Turonian ammonites from Texas and Mexico: Journal of Paleontology, v. 28, no. 3, p. 310-319, pls. 30-33.

Lamb, G. M., 1968, Stratigraphy of the lower Mancos Shale in the San Juan Basin: Geological Society of America Bulletin, v. 79, no. 7, p. 827-854

Leanza, A. F., 1967, Algunos ammonites nuevos o poco conocidos del Turoniano de Colombia y Venezuela: Acta Geological Lilloana, v. 9, p. 189-229, 7 pls.

Lee, W. T., 1912, Stratigraphy of the coal fields of northern central New Mexico: Geological Society of America Bulletin, v. 23, p. 571-686.

1917 [1918], Geology of the Raton Mesa and other regions in Colorado and New Mexico, in W. T. Lee and F. H. Knowlton, Geology and paleontology of the Raton Mesa and other regions in Colorado and New Mexico: U.S. Geological Survey Professional Paper 101, p. 9-221, illus.

Lewy, Zeev, 1975, The geological history of southern Israel and Sinai during the Coniacian: Israel Journal of Earth-Sciences, v. 24, p. 19-43, 1 pl.

Magalhães, Júlio, 1952, Contribuicão ao conhecimento do Cretácico de Sergipe: Universidade do Brasil Revista Cientıfica, v. 3, nos. 1-2, p. 7-23.

1953, Nova espécie de Hoplitoides do Cretácico de Sergipe: Universidade do Brasil Revista Científica, v. 4, nos. 3-4, p. 47-53.

Matsumoto, Tatsuro, 1970, Uncommon keeled ammonites from the Upper Cretaceous of Hokkaido and Saghalien: Kyushu University, Memoirs of the Faculty of Science, ser. D, Geology, v. 20, no. 2 , p. $305-317$, pls. 48,49 .

Oliveira, P. E., 1969, Nôvo amonoide do Cretáceo do Ceará: Universidade Federal do Rio de Janeiro, Instituto de Geosciências Boletim Geologia 4, p. 5-9, 1 pl.

Oliveira, P. E., de, and Brito, I. M., 1969, Amonitas Turonianos do Estado de Sergipe: Anais da Academia Brasileria de Ciências, v. 41 , no. 2 , p. $215-233,5$ pls.

Orbigny, Alcide d', 1840-42, Céphalopodes-Paleontologie francaise, terrain Crétacé: Paris, Masson et Cie, 1st ser., v. 1, 662 p., 148 pls.

Parnes, A., 1964, Coniacian ammonites from the Negev (southern Israel): Israel Geological Survey Bulletin 39, 41 p., 4 pls.

Peron, Alphonse, 1896-97, Les ammonites du crétacé supérieur de l'Algérie: Société Géologique de France Mémoire 17, Paléontologie, 88 p., 18 pls. (1896, v. 6, pt. 4, p. 1-24, pls. 1-6 (14-19); 1897 , v. 7, pts. 1 and 2, p. 25-88, pls. 7-18 (1-12))

Pervinquiere, Leon, 1907, Études de paléontologie tunisienne, [Part] 1, Céphalopodes des terrains secondaires: Carte Géologique de la Tunisie, 438 p., 27 pls.

1910, Sur quelques ammonites du Crétacé algérien: Société Géologique de France Mémoire 42, Paléontologie, v. 17, pts. 2-3, p. 1-86, pls. 10-16 (1-7).

Powell, J. D., 1963, Turonian (Cretaceous) ammonites from northeastern Chihuahua, Mexico: Journal of Paleontology, v. 37, no. 6, p. 1217-1232.

1965, Late Cretaceous platform-basin facies, northern Mexico and adjacent Texas: American Association of Petroleum Geologists Bulletin, v. 49, no. 5, p. 511-525.

Renz, Otto, 1959, Estratigracia del Cretaceo en Venezuela Occidental: Venezuela Ministerio de Minas e Hidrocarburos Boletin de Geologia, v. 5, no. 10, p. 3-48. 
Reyment, R. A., 1954a, New Turonian (Cretaceous) ammonite genera from Nigeria: Colonial Geology and Mineral Resources, v. 4, no. 2 , p. 149-164, 4 pls.

1954b, Some new Upper Cretaceous ammonites from Nigeria: Colonial Geology and Mineral Resources, v. 4, no. 3, p. 248-270, 5 pls.

1955a, Some examples of homeomorphy in Nigerian Cretaceous ammonites: Geologiska Föreningens i Stockholm Förhandlingar, v. 77, pt. 4, p. 567-594.

1955b, The Cretaceous Ammonoidae of southern Nigeria and the southern Cameroons: Nigeria Geological Survey Bulletin 25, 112 p., 25 pls.

1956 , On the stratigraphy and palaeontology of the Cretaceous of Nigeria and the Cameroons, British West Africa: Geologiska Föreningens i Stockholm Förhandlingar, v. 78, pt. 1, no. 484, p. 17-96.

1970, Note sur le genre Hoplitoides dans l'Atlantique du Sud: Bulletin de la Société Géologique de France, 7th ser., v. 12, p. 913-915, pl. 35 .

1971, Experimental studies of Cretaceous transgressions for Africa: Geological Society of America Bulletin, v. 82, no. 4, p. 1063-1072.

1972, Some lower Turonian ammonites from Trinidad and Colombia: Geologiska Föreningens i Stockholm Förhandlingar, v. 94 , pt. 2, p. $357-368$.

1976 [1978], The mid-Cretaceous of the Nigerian coastal basin: Annales du Museum d'Histoire Naturelle de Nice, v. 4, p. 20.1-20.15.

Riedel, Leonhard, 1932, Die Oberkreide vom Mungofluss in Kamerun und ihre Fauna: Beiträge zur Geologischen Erforschung der Deutschen Schutzgebiete, no. 16, 154 p., 33 pls.

Roman, Frédéric, and Mazeran, Pierre, 1920, Monographie paléontologique de la faune de Turonien de Bassin d'Uchaux et de ses dépendances: Archives du Museum d'Histoire Naturelle de Lyon, v. 12, 138 p., 11 pls.
Schneegans, Daniel, 1943, Invertébrés du Crétacé supérieur du Damergou (Territoire du Niger), in Etudes stratigraphiques et paléontologiques sur le Bassin du Niger: French West Africa Direction Mines Bulletin 7, p. 87-150, 8 pls.

Serna, F. E., 1964, Posición de las faunas en los depósitos cretácicos colombianos y su valor en la subdivisión cronológica de los mismos: [Colombia] Universidad Industrial de Santander Boletin Geologia, nos. 16-17, 142 p.

Solger, Friedrich, 1904, Die Fossilien der Mungokreide in Kamerun und ihre geologische Bedeutung mit besonderer Berücksichtigung der Ammoniten, in Esch, Ernst, Solger, Friedrich, Oppenheim, Paul, and Jaekel, O., Beiträge zur Geologie von Kamerun, Part 2: Stuttgart, E. Schweizerbartsche Verlagsbuchhandlung, p. 88-242, pls. 3-5.

Vredenburg, E. W., 1907, The ammonites of the Bagh beds: Geological Survey of India Records, v. 36, pt. 2, p. 109-125, pls. 14-17.

Wasson, Theron, and Sinclair, J. H., 1927, Geological explorations east of the Andes in Ecuador: American Association of Petroleum Geologists Bulletin, v. 11, no. 12, p. 1253-1281, pls. 9-13.

Wiedmann, Jost, 1959 [1960], Le Crétacé supérior de l'Espagne et du Portugal et ses Céphalopodes, in Colloque Crétacé supérieur français: 84e Congrés des Sociétés Savantes de Paris et des Départements, Dijon, 1959, Section des Sciences, Comptes Rendus Colloque Crétacé, p. 709-764, 8 pls.

Wright, C. W., 1957, Family Coilopoceratidae [p. L424-L426] in W. J. Arkell, Bernhard Kummel, and C. W. Wright, Mesozoic Ammonoidea, in Part L, Mollusca 4, of R. C. Moore, ed., Treatise on invertebrate paleontology: New York and Lawrence, Kans., Geological Society of America and Kansas University Press, 490 p., 558 text figs.

Young, Keith, and Powell, J. D., 1976 [1978], Late Albian-Turonian correlations in Texas and Mexico: Annales du Museum d'Histoire Naturelle de Nice, v. 4, p. 25.1-25.36, 9 pls. 


\section{INDEX}

[Italic page numbers indicate major references]
Page

A

Aconeceras

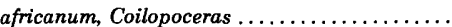
Angola, Coilopoceras

autenriethi, Hoplitoides ...................

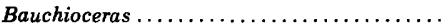

bellaplicata novimexicana, Lopha ...........

benueensis, Benneites.

Benueites benueensis

bipartitus, Hoplitoides gibbosulus ........

brasiliensis, Coilopoceras ...................

Brazil, Coilopoceras ......................

Hoplitoides
Abstract .............................

Hoplitoides .........................

Coilopoceras-Continued

Page

springeri

$18,19,20,23,24$

pls. $1,3,6,10,18,19$

zihoricum .......... 11

Coilopoceratidae, definition .............. 5

colleti, Coilopoceras ............ 1, 6, 11, 12, 13, 14, 15

$16,19,20,23,24$

pls. $1,3,5,6,7,8,9$

Collignoniceras woollgari $\ldots \ldots \ldots \ldots \ldots \ldots \ldots \ldots, 1,24, \ldots \ldots \ldots, 13,23,24$
woollgari $\ldots \ldots \ldots \ldots \ldots \ldots \ldots \ldots \ldots$ woollgari ..................... $7,13,23,24$

Colombia, Coilopoceras ................... 12

Hoplitoides ....................... 6

Colorado, Coilopoceras .................... $\quad 12$

Coniacian age, Coilopoceras .............. 12

Hoplitoidea

costata, Placenticeras ....................

costatum, Herrickiceras ............. 22, 23, 24, pl. 19

Placenticeras ..................... 22

costatus, Hoplitoides ingens ............. 5

crassicostatus, Hoplitoides ............. 5,6

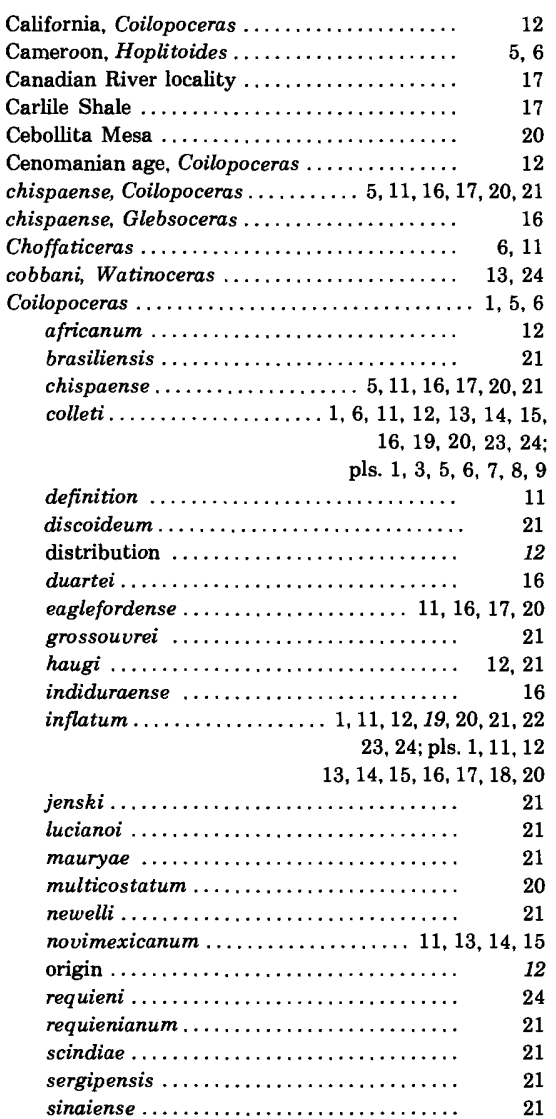

\section{D}

D-Cross Tongue, Mancos Shale ............ 20

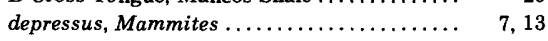
deveriai Romaniceras .................. 24

dimidius, Inoceramus ................. 22, 24

discordeum, Coilopoceras ...................

duartei, Coilopoceras ................... $\quad 16$

E, F, G

eaglefordense, Coilopoceras.......... 11, 16, 17, 20 Ecuador, Coilopoceras ................... 12 Egypt, Hoplitoides .................... 6

France, Coilopoceras ................... 12 Hourcquia ........................ 24 Fossil localities ......................

gibbosula, Pulchellia .

gibbosulus, Hoplitoides.

bipartitus, Hoplitoides ................

makurdiensis, Hoplitoides ..............

Glebosoceras ....

glebosum

glebosum, Glebosoceras

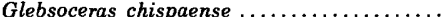

grossouvrei, Coilopoceras ................

guentheri, Watinoceras

H

haugi, Coilopoceras .................. 12, 21 Herrickiceras ........................ costatum ................., 22, 23, 24; pl. 19 definition $\ldots \ldots \ldots \ldots \ldots \ldots \ldots \ldots \ldots \ldots, 22$

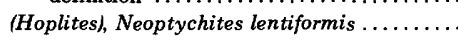
wohltmanni...
Donenriquoceras . ........................ $\quad 22$

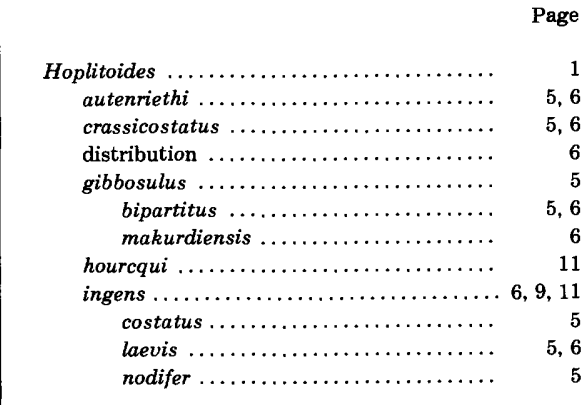

koeneni............. 5, 6, 7, 12, 23; pls. 1,3 latesellatus ........................ 5,6 munieri $\ldots \ldots \ldots \ldots \ldots \ldots \ldots \ldots \ldots \ldots, 22,23$ origin $\ldots \ldots \ldots \ldots \ldots \ldots \ldots \ldots \ldots \ldots, 6$ sandovalensis ............. 6, 8,11, 13, 22, 23 , 24; pls. $23,4,11,18$ solgeri $\ldots \ldots \ldots \ldots \ldots \ldots \ldots \ldots \ldots \ldots, \quad 5,6$ wilsingi ......................... 5,6 wohltmanni ............. 5, 6, 7, 8, 12, 23; pl. 1 hourcqui, Hoplitoides ................. 11 Hourcquia mirabilis .................... 24 howelli, Inoceramus .................. 17, 24 hyatti, Prionocyclus . .......... 6, 11, 12, 13, 17, 24 I

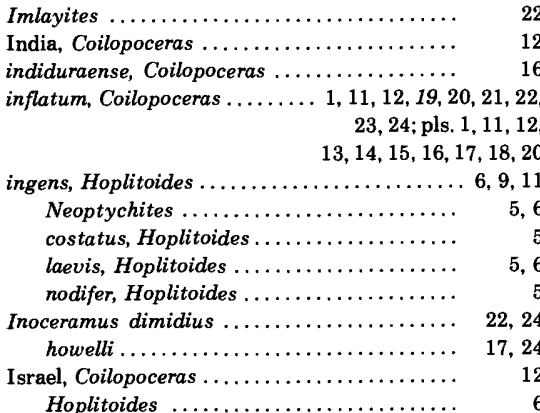
J, K, L

Japan, Hourcquia ................... 24 jenski, Coilopoceras ..................... 21 Jordan, Hoplitoides . . . . . . . 6

koeneni, Hoplitoides . ........ 5, 6, 7, 12, 23, pls. 1, 3

laevis, Hoplitoides ingens ................ 5, 6 latesellatus, Hoplitoides................ 5,6

Lebanon, Coilopoceras ................... $\quad 12$ Hoplitoides ..................... 6 lentiformis, Neoptychites (Hoplites) .......... leonhardianum, Paralenticeras ............. 12

Leoniceras quassi..................... $\quad 11$

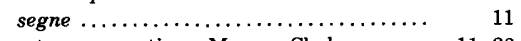
Limestone concretions, Mancos Shale ....... 11, 23 Lincoln County, N. Mex............... 20

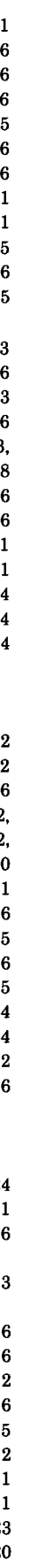




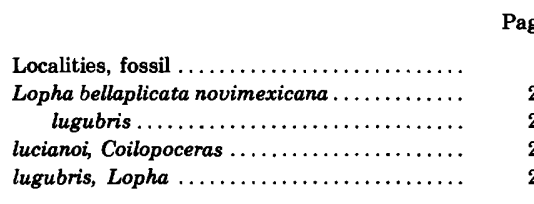

$\mathbf{M}$

macombi, Prionocyclus ................. 12, 15, 24

Madagascar, Coilopoceras ..................

Hoplitoides

Hourcquia ......................

makurdiensis, Hoplitoides gibbosulus ........

Mammites depressus

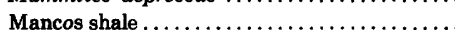

D-Cross Tongue

limestone concretions

Semilla Sandstone Member ........... 13, 17, 24

Tres Hermanos Sandstone Member...... 7, 13

mauryae, Coilopoceras ......................

mexicanum, Selwynoceras ................

Mexico, Coilopoceras .................... 12

Herrickiceras . . . . . . . . . . . . . . . . .

Hoplitoides

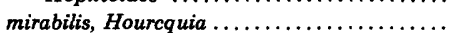

multicostatum, Coilopoceras ................

Mungo River locality, Hoplitoides ...........

munier, Hoplitoides .

\section{$\mathrm{N}, \mathrm{O}$}

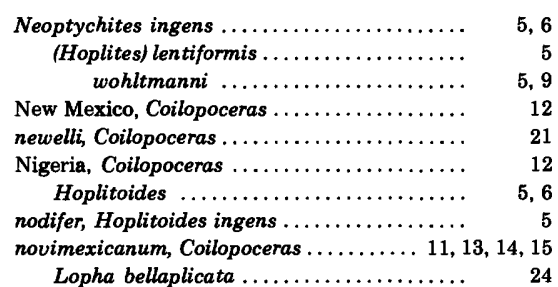

Oscura area, N. Mex.

\begin{tabular}{|c|c|}
\hline \multicolumn{2}{|l|}{ 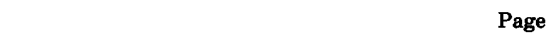 } \\
\hline \multicolumn{2}{|l|}{$\mathbf{P}$} \\
\hline Paralenticeras leonhardianum ... & 12 \\
\hline Peru, Coilopoceras ............. & 12 \\
\hline Hoplitoides ..... & 6 \\
\hline Placenticeras costata & 1 \\
\hline costatum ........... & 22 \\
\hline \multirow{2}{*}{\multicolumn{2}{|c|}{$\begin{array}{r}\text { Prionocyclus hyatti } \ldots \ldots \ldots \ldots \ldots \ldots, 11,12,13,17,24 \\
\text { macombi } \ldots \ldots \ldots \ldots \ldots \ldots \ldots \ldots \ldots \ldots \ldots 12,15,24\end{array}$}} \\
\hline & \\
\hline wyomingensis ..................... & 22,24 \\
\hline \multicolumn{2}{|l|}{ Proplacenticeras pseudoplacenta...........11, 12, 17} \\
\hline 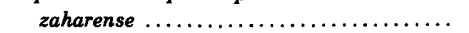 & 24 \\
\hline pseudoplacenta, Proplacenticeras ......... 11 & 12,17 \\
\hline Pseudotissotia segnis .................. & 11 \\
\hline Pseudotissotiidae ...................... & 6 \\
\hline \multicolumn{2}{|c|}{ puercoensis, Spathites ............... 11, 13, 17, 24} \\
\hline \multicolumn{2}{|c|}{ Pulchellia gibbosula .................. } \\
\hline \multicolumn{2}{|l|}{$\mathbf{Q}, \mathbf{R}$} \\
\hline quassi, Leoniceras ..... & 11 \\
\hline$\ldots, \cdots, \cdots, \cdots, \cdots$, & 24 \\
\hline opoceras ................ & 21 \\
\hline (n................... & 17 \\
\hline ndoval County .......... & 23 \\
\hline$s \ldots \ldots \ldots \ldots \ldots \ldots \ldots \ldots$ & 13 \\
\hline Romaniceras deveriai ................... & 24 \\
\hline $\mathbf{S}$ & \\
\hline & 17 \\
\hline Sandoval County, N. Mex., Herrickiceras ...... & 23 \\
\hline Hoplitoides $\ldots \ldots \ldots \ldots \ldots \ldots \ldots \ldots$ & \\
\hline $\begin{array}{r}\text { sandovalensis, Hoplitoides . . } \ldots \ldots \ldots 6,8,11,13 \\
24 ; \text { pls. } 2,3,4\end{array}$ & $\begin{array}{l}22,23 \\
11,18\end{array}$ \\
\hline ................ & 12,22 \\
\hline Schloenbachiids $\ldots \ldots \ldots \ldots \ldots \ldots \ldots \ldots \ldots$ & 12 \\
\hline schweinfurthi, Tissotia ................. & 11 \\
\hline scindiae, Coilopoceras .................. & 21 \\
\hline segne, Leoniceras . . . . . . . . . . . . . . . & 11 \\
\hline tissotia $\ldots \ldots \ldots \ldots \ldots \ldots \ldots$ & 11 \\
\hline Selwynoceras mexicanum .................. & 23 \\
\hline Semilla Sandstone Member, Mancos Shale ... 13 & 17,24 \\
\hline sergipensis, Coilopoceras ................. & 21 \\
\hline Shuparoceras ................... 11, 13, $1^{\prime}$ & 19,24 \\
\hline sinaiense, Coilopoceras ................... & 21 \\
\hline socorroense, Tragodesmoceras .............. & 12 \\
\hline
\end{tabular}

Page

solgeri, Hoplitoides

Spain, Hoplitoides

5,6

Spathites puercoensis rioensis $11,13,17,24$

springeri, Coilopocera $1,5,11,12,13,16,17$, $18,19,20,23,24$ pls. $1,3,6,10,18,19$

T, V

Tethyan belt, Coilopoceras ............... 12

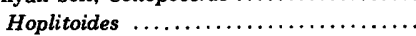

Tethyan region....

Texas, Coilopoceras .

Tissotia schweinfurthi

Tragodesmoceras socorroense

Tres Hermanos Sandstone Member, Mancos

Trinidad, Coilopoceras .................... Hoplitoides

Tunisia, Hoplitoides ..................... 1

Valencia County, N. Mex.

Venezuela, Coilopoceras

Hoplitoides

$\mathbf{W}, \mathbf{z}$

warreni, Scaphites ................... 12, 22

Watinoceras cobbani ................... 13, 24 quentheri $\ldots \ldots \ldots \ldots \ldots \ldots \ldots \ldots \ldots, \quad 24$ wilsingi Hoplitoides .................. 5,6 wohltmanni, Hoplitoides ........ 5, 6, 7, 8, 12, 23; pl. 1 Neoptychites (Hoplites) ............. 5, 9 woollgari, Collignoniceras ................. woollgari .................. 7, 13, 23, 24 woollgari, Collignoniceras ......... 7, 13, 23, 24 Wrightoceras ........................ 6 Wyoming, Coilopoceras .................. 12 wyomingensis, Prionocyclus ............. 22, 24

zaharense, Proplacenticeras .............. 24 zihoricum, Coilopoceras .................. 11 


\section{PLATES 1-21}

Contact photographs of the plates in this report are available, at cost, from the U.S. Geological Survey Photographic Library, Federal Center, Denver, Colorado 80225. 


\section{PLATE 1}

[All figures natural size]

Figures 1, 2. Hoplitoides cf. H. koeneni Solger (p. 6).

Figured specimen USNM 252968, from USGS Mesozoic locality D10260 (text fig. 1, loc. 48). See plate 3, figures 4, 5, for inner whorl, text figure 2 for whorl section, and text figure $3 A$ for suture.

3, 4. Hoplitoides cf. H. wohltmanni (von Koenen) (p. 7).

Hypotype USNM 252969, from USGS Mesozoic locality D5773 (text fig. 1, loc. 45). See text figure 4 for suture.

5, 6. Coilopoceras springeri Hyatt (p. 16).

Hypotype USNM 275906, from USGS Mesozoic locality D3884 (text fig. 1, loc. 10).

7, 8. Coilopoceras colleti Hyatt (p. 13).

Small specimen showing unusual dense and flexuous ribbing. Hypotype USNM 275886 from USGS Mesozoic locality 17632 (text fig. 1, loc. 2).

9-11. Coilopoceras inflatum Cobban and Hook, n. sp. (p. 19).

Paratype USNM 275921, from USGS Mesozoic locality D2055 (text fig. 1, loc. 40). 
GEOLOGICAL SURVEY
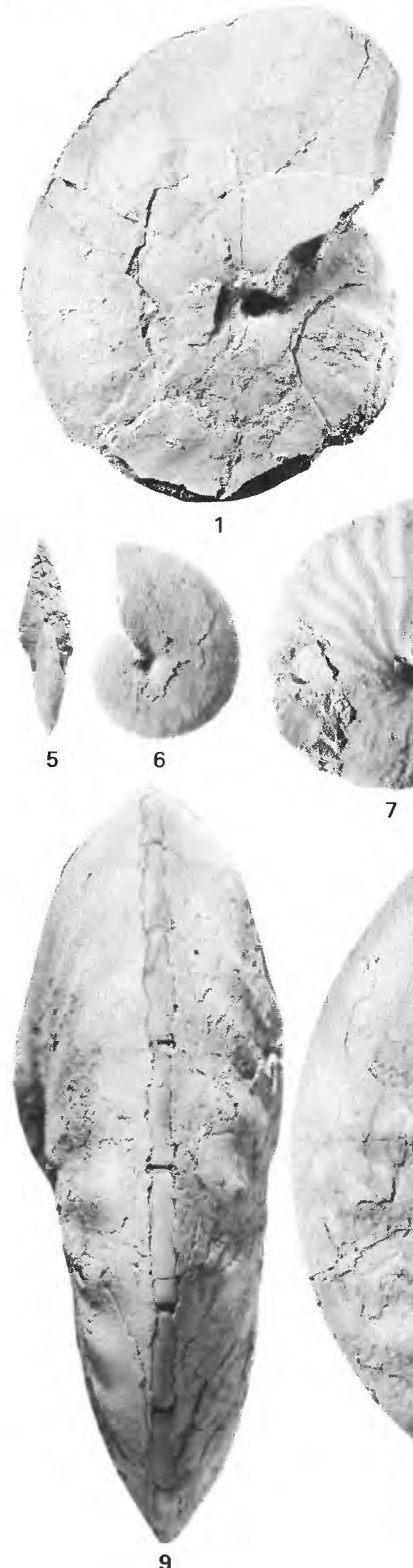

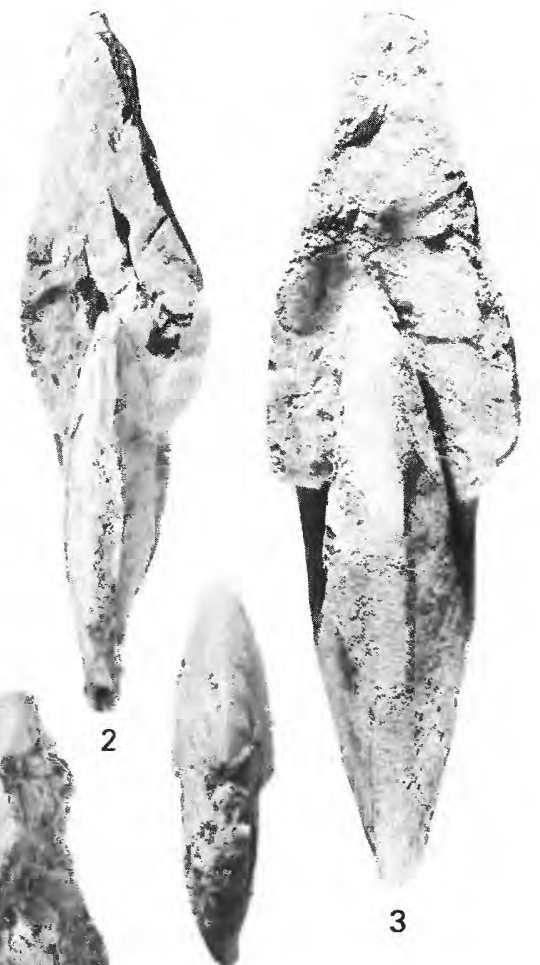

PROFESSIONAL PAPER 1192 PLATE 1
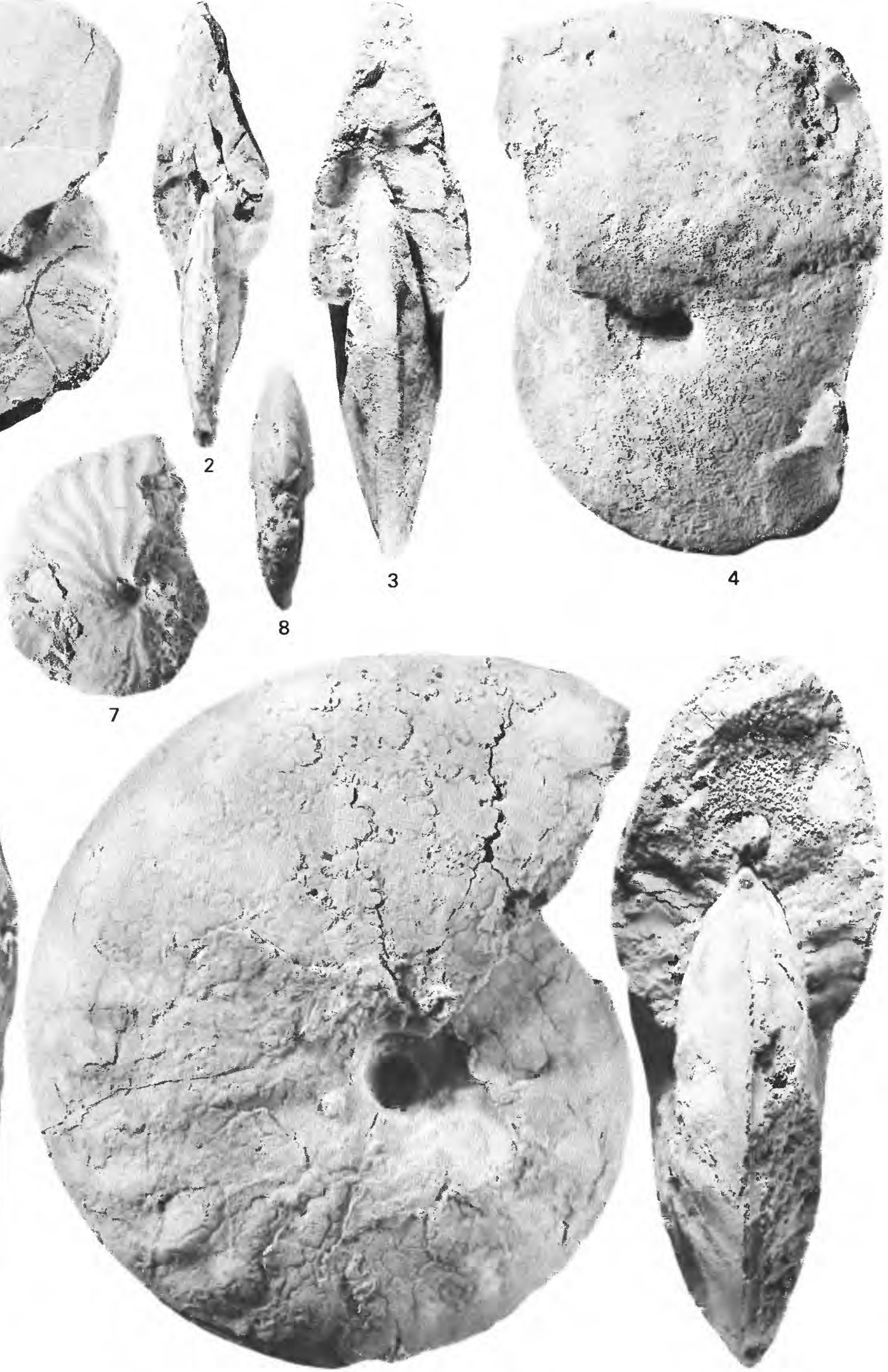

10

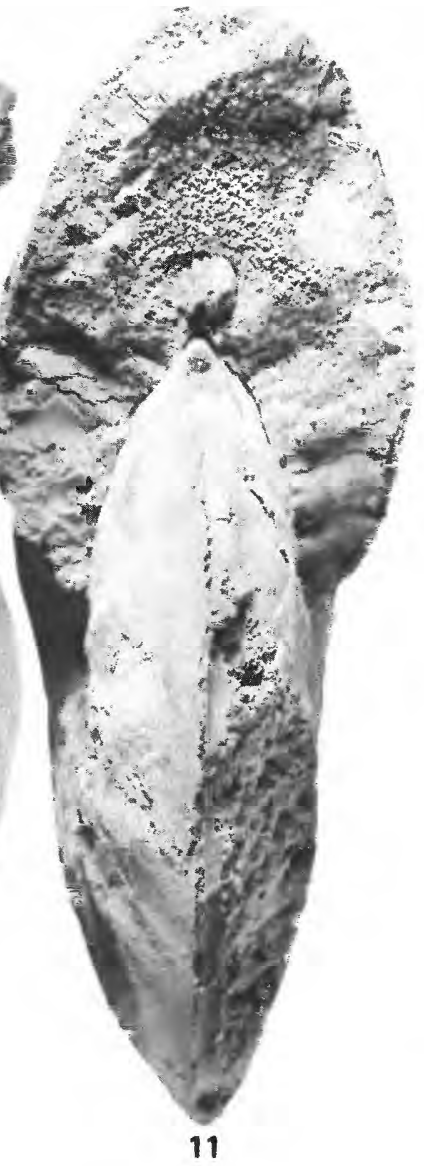

HOPLITOIDES AND COILOPOCERAS 


\section{PLATE 2}

[All figures natural size]

Figures 1-11. Hoplitoides sandovalensis Cobban and Hook, n. sp. (p. 8).

1-3. Paratype USNM 275878, from USGS Mesozoic locality 15947 (text fig. 1, loc. 29).

4, 5. Paratype USNM 275879, from USGS Mesozoic locality 15925 (text fig. 1, loc. 28).

6, 7. Holotype USNM 275877, from USGS Mesozoic locality 15947 (text fig. 1, loc. 29).

8-10. Paratype USNM 275880, from USGS Mesozoic locality 15799 (text fig. 1, loc. 30). See text figure $7 D$ for suture.

11. Paratype USNM 275881, from USGS Mesozoic locality 15797 (text fig. 1, loc. 34). See plate 3, figures 15,16 for other views. 

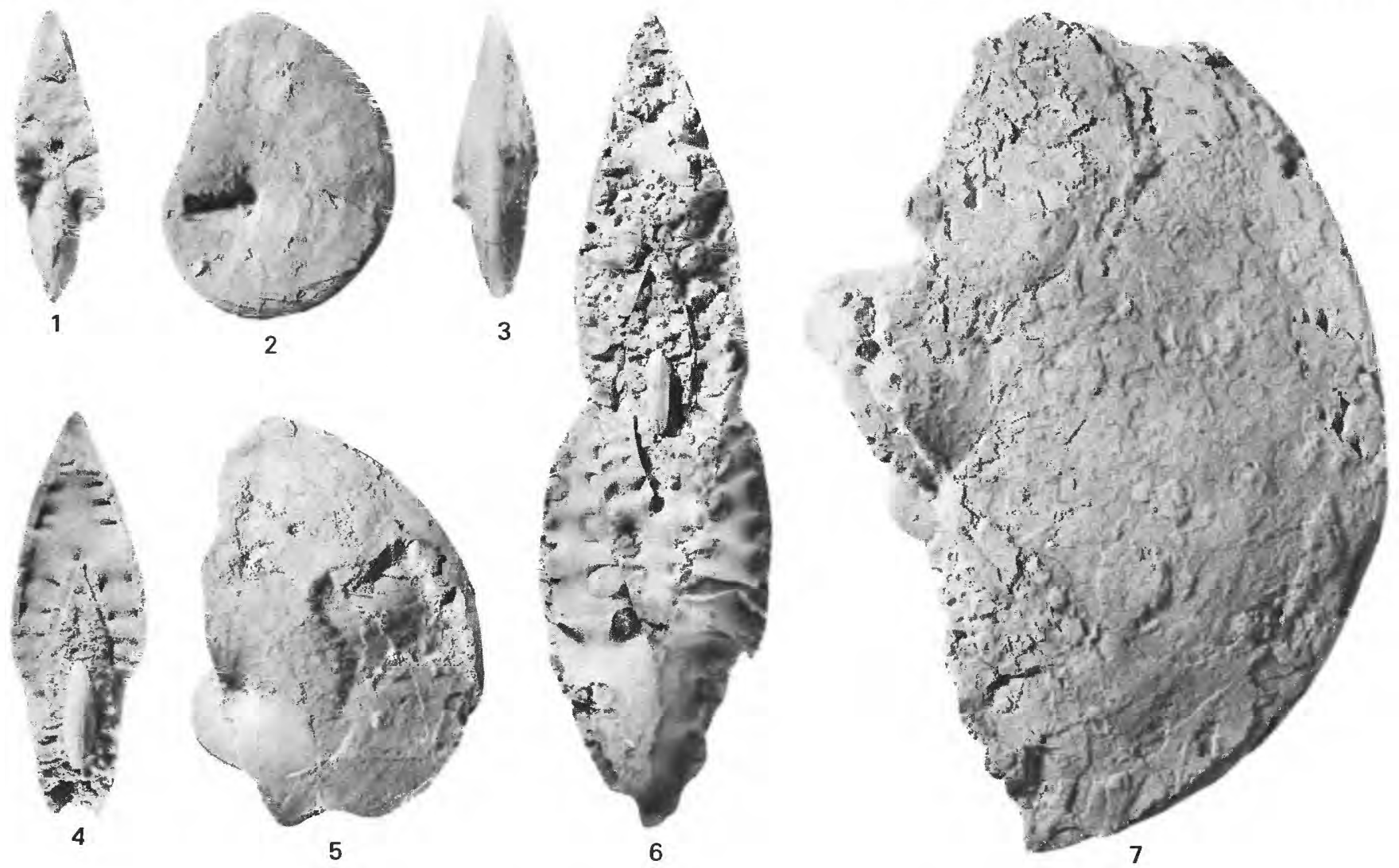

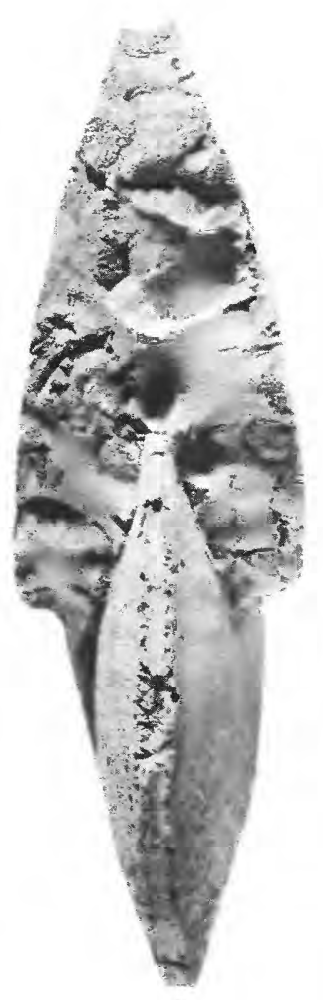

8
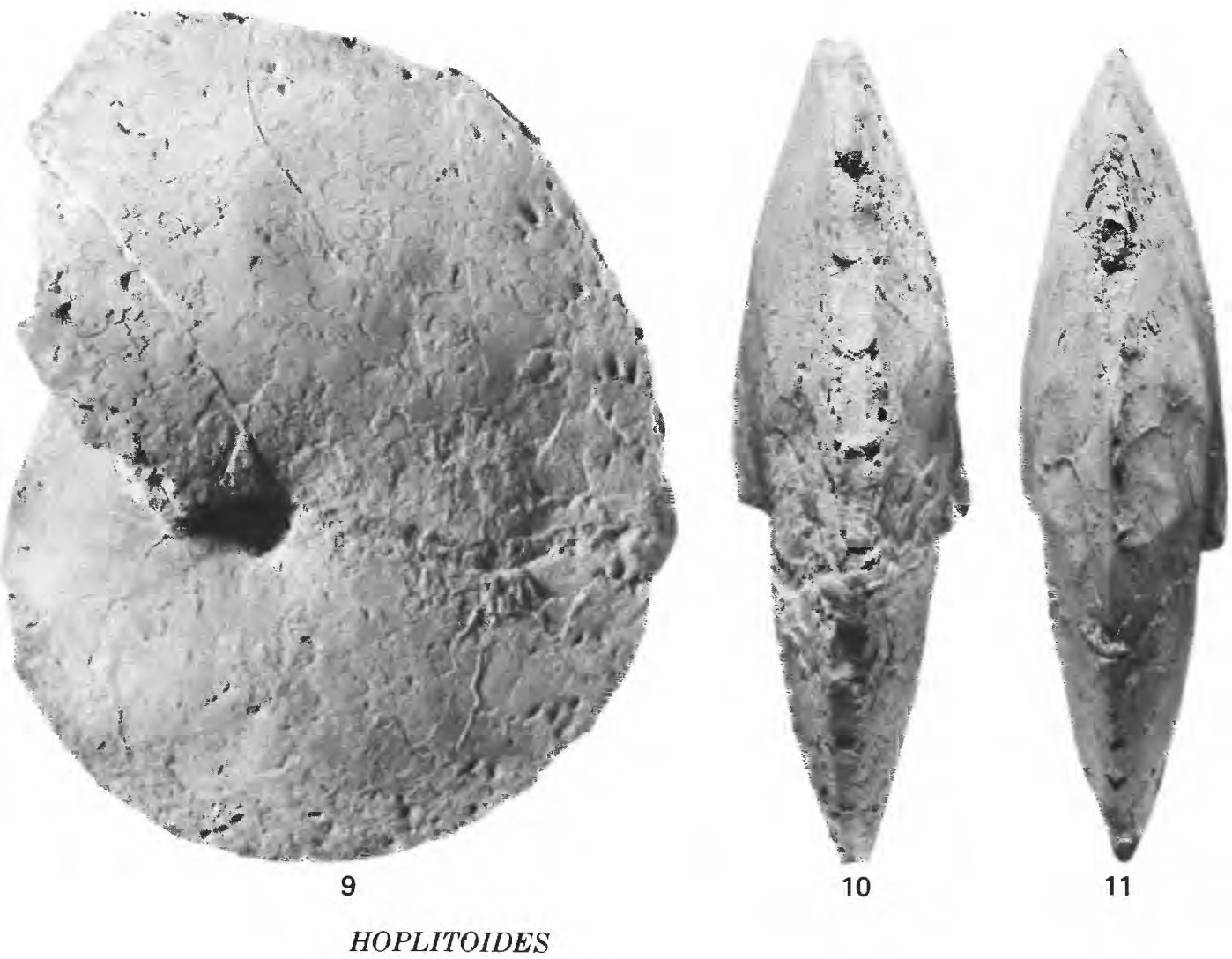

HOPLITOIDES 
PLATE 3

[All figures natural size]

Figures 1-3. Coilopoceras colleti Hyatt (p. 13).

Hypotype USNM 275887, from USGS Mesozoic locality D3702 (text fig. 1, loc. 41).

4, 5. Hoplitoides ef. H. koeneni Solger (p. 6).

Views of the inner whorls of the specimen shown on plate 1, figures 1, 2. Figured specimen USNM 252968.

6-8, 12-16. Hoplitoides sandovalensis Cobban and Hook, n. sp. (p. 8).

6-8. Paratype USNM 275882, from USGS Mesozoic locality 15947 (text fig. 1, loc. 29).

12-14. Paratype USNM 275883, from USGS Mesozoic locality 3672 (text fig. 1, loc. 31). See text figure $7 B$ for suture.

15, 16. Paratype USNM 275881, from USGS Mesozoic locality 15797 (text fig. 1, loc. 34). See text figure $7 A$ for suture.

9-11. Coilopoceras springeri Hyatt (p. 16).

Hypotype USNM 275907, from USGS Mesozoic locality D3670 (text fig. 1, loc. 6). See text figure $11 B$ for suture. 

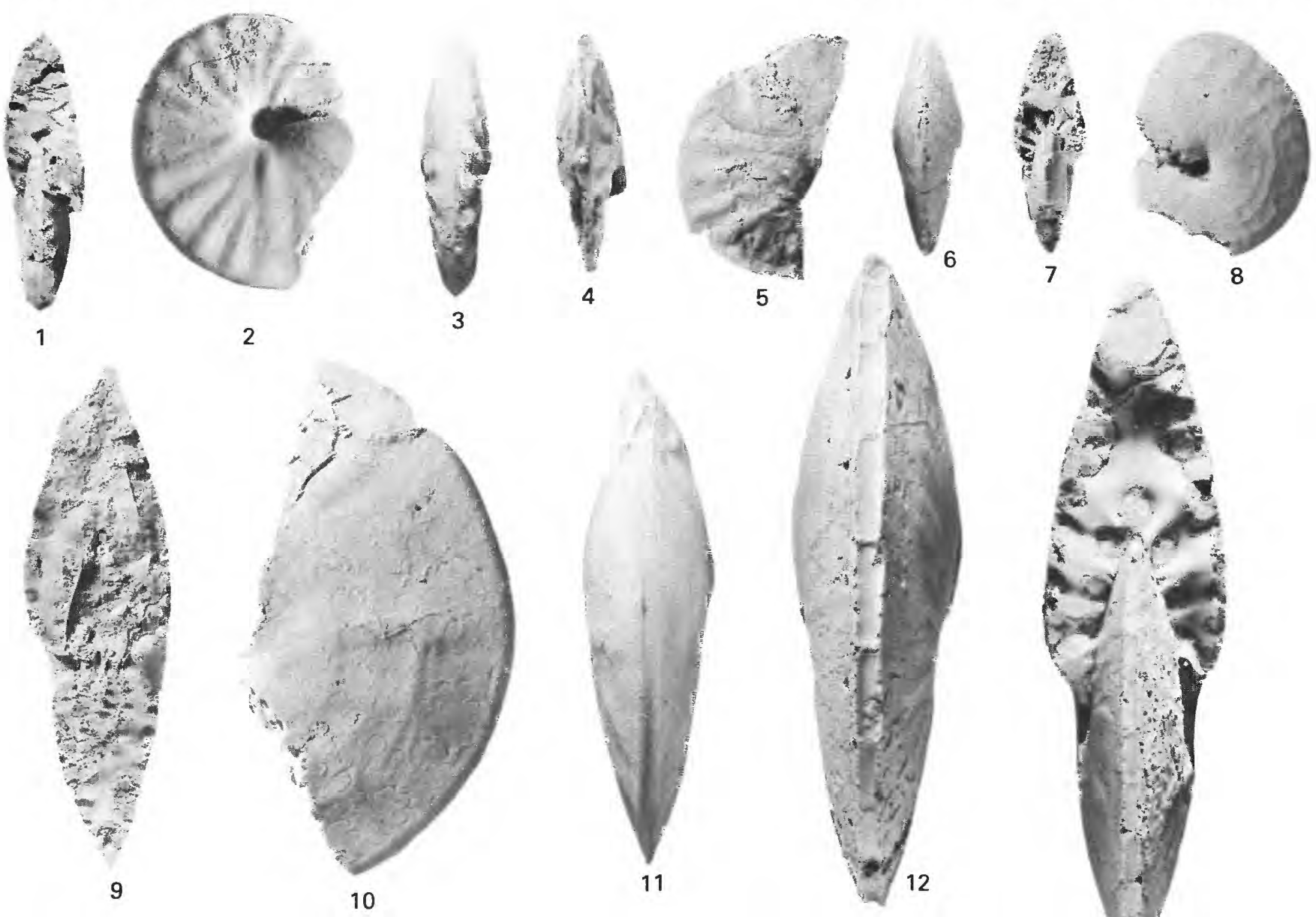

9
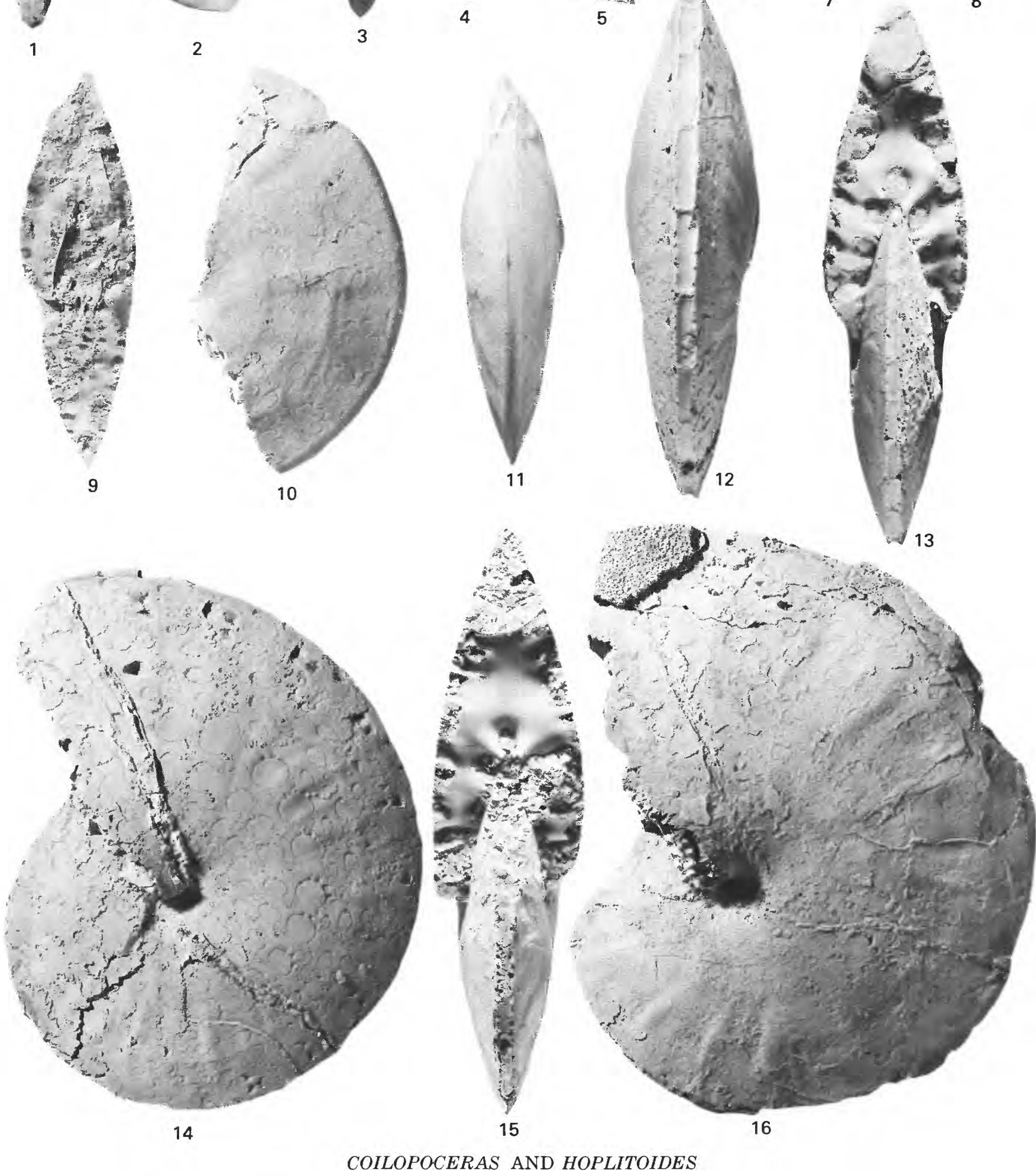


\section{PLATE 4}

[Figure natural size]

Hoplitoides sandovalensis Cobban and Hook, n. sp. (p. 8).

Side view of paratype USNM 257884, from USGS Mesozoic locality D10508 (text fig. 1, loc. 27). See plate 11, figure 1 for front view, and text figure $7 C$ for suture. 


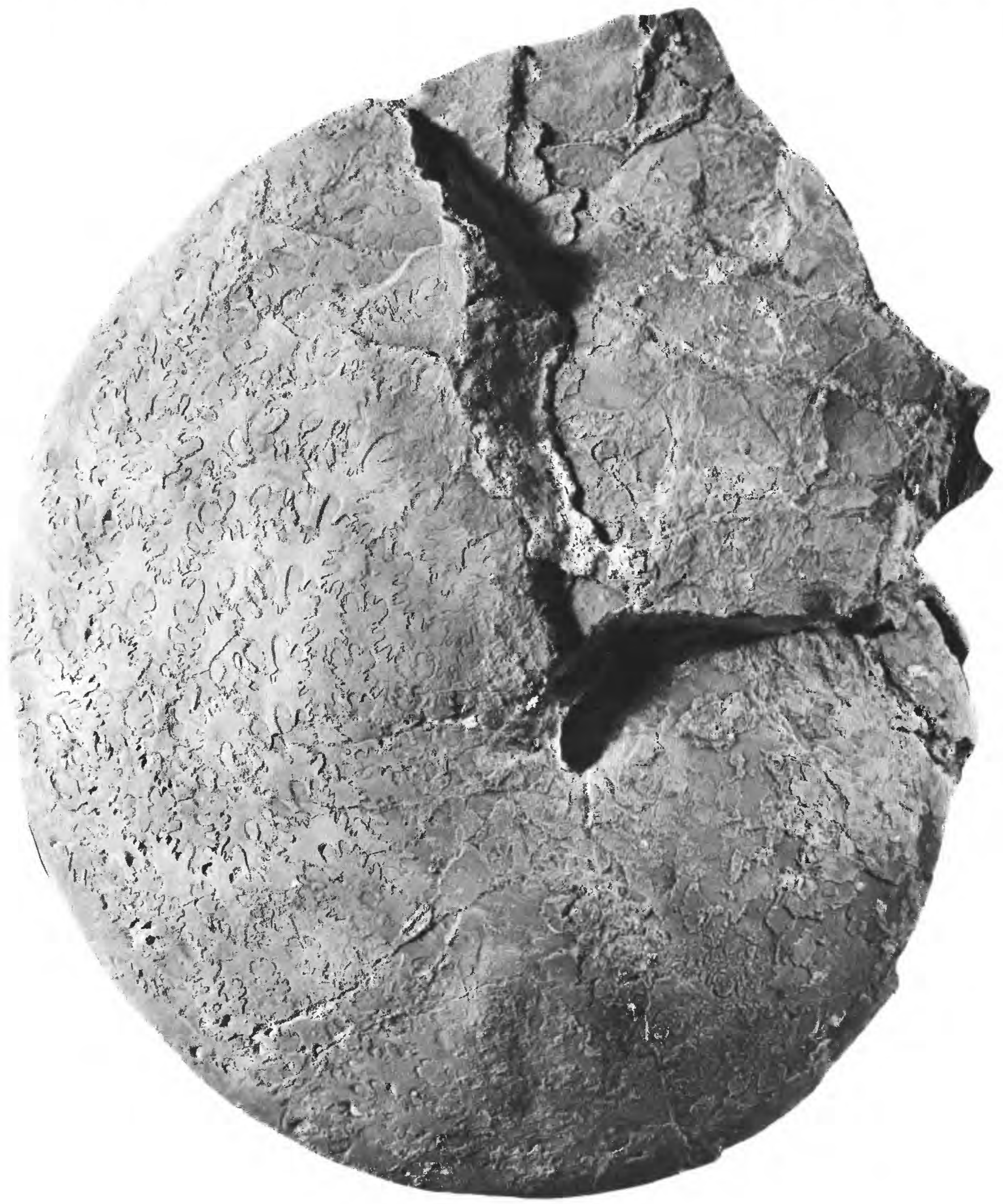




\title{
PLATE 5
}

\author{
[All figures natural size]
}

Figures 1-15. Coilopoceras colleti Hyatt (p. 13).

1-3. Hypotype USNM 275888, from USGS Mesozoic locality D10354 (text fig. 1, loc. 51).

4-6. Hypotype USNM 275889, from the same locality.

7-9. Hypotype USNM 275890, from USGS Mesozoic locality D4395 (text fig. 1, loc. 3).

10. Hypotype USNM 275891, from USGS Mesozoic locality D10630 (text fig. 1, loc. 53).

11, 12. Hypotype USNM 275892, from USGS Mesozoic locality D4395 (text fig. 1, loc. 3).

13. Hypotype USNM 275893, from USGS Mesozoic locality D10354 (text fig. 1, loc. 51).

14,15 . Hypotype USNM 275894, from the same locality as figure 13 . See text figure $10 \mathrm{~A}$ for the suture. 


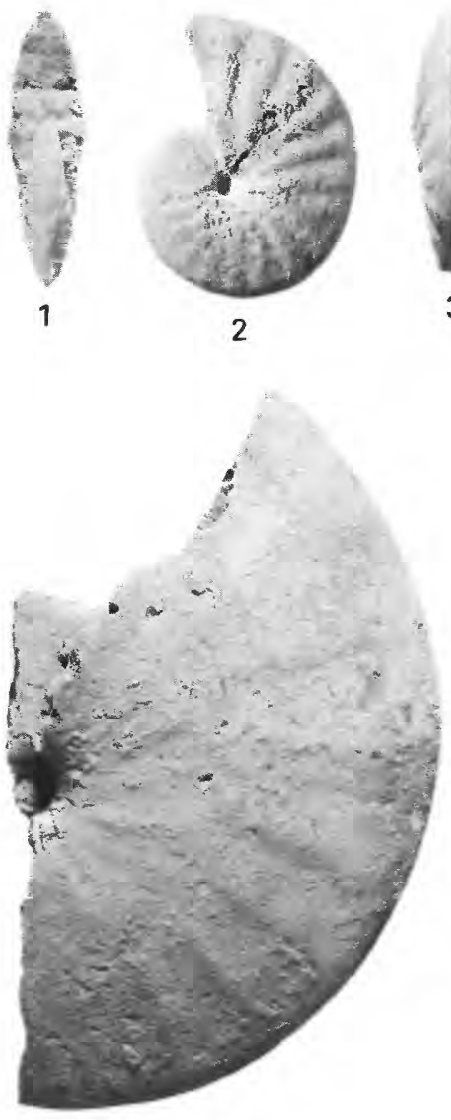

9

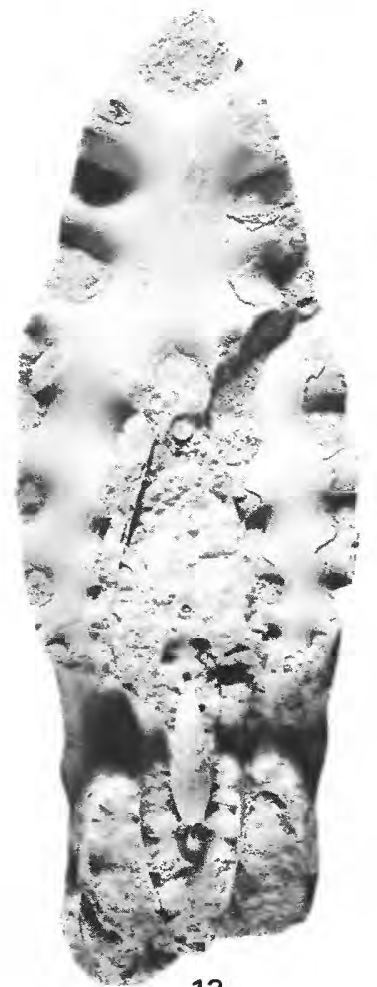

13
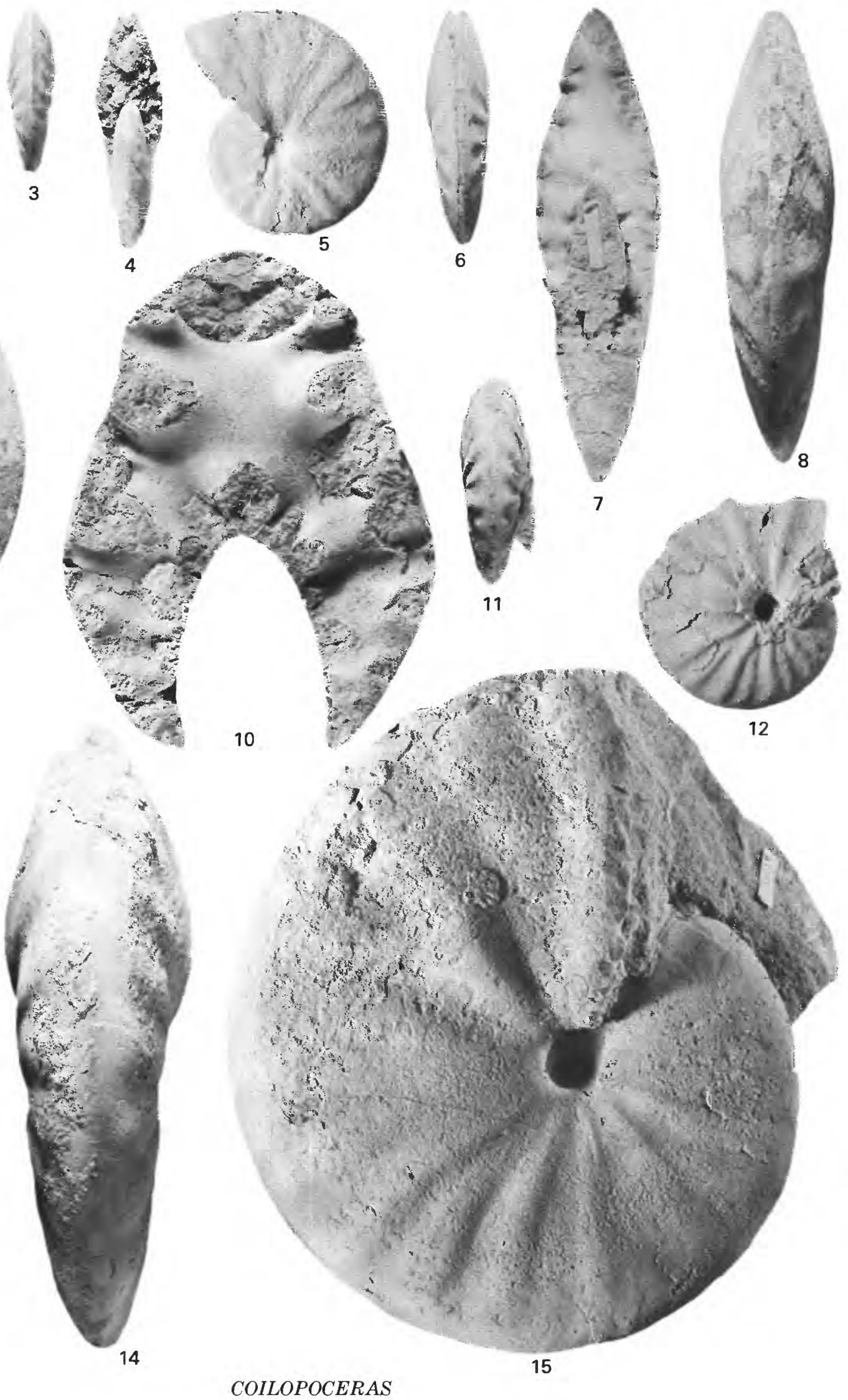
PLATE 6

[All figures natural size]

Figures 1-8. Coilopoceras colleti Hyatt (p. 13).

1-3. Hypotype USNM 275896, from USGS Mesozoic locality D10354 (text fig. 1, loc. 51).

4, 5. Hypotype USNM 275897, from the same locality.

6-8. Hypotype USNM 275898, from USGS Mesozoic locality D4395 (text fig. 1, loc. 31).

9, 10. Coilopoceras springeri Hyatt (p. 16).

Hypotype USNM 278122, from the type locality of $C$. springeri along Rio del Plano at USGS Mesozoic locality D10739 (text fig. 1, loc. 59). 


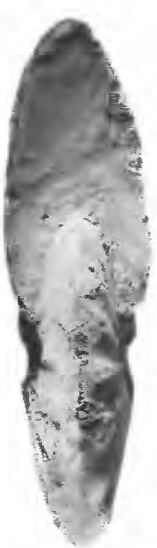

1

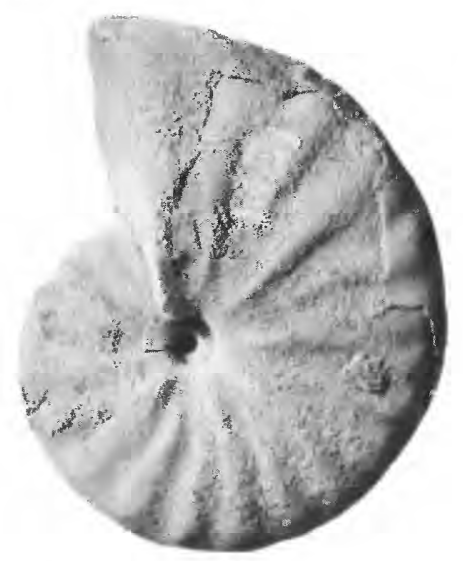

2
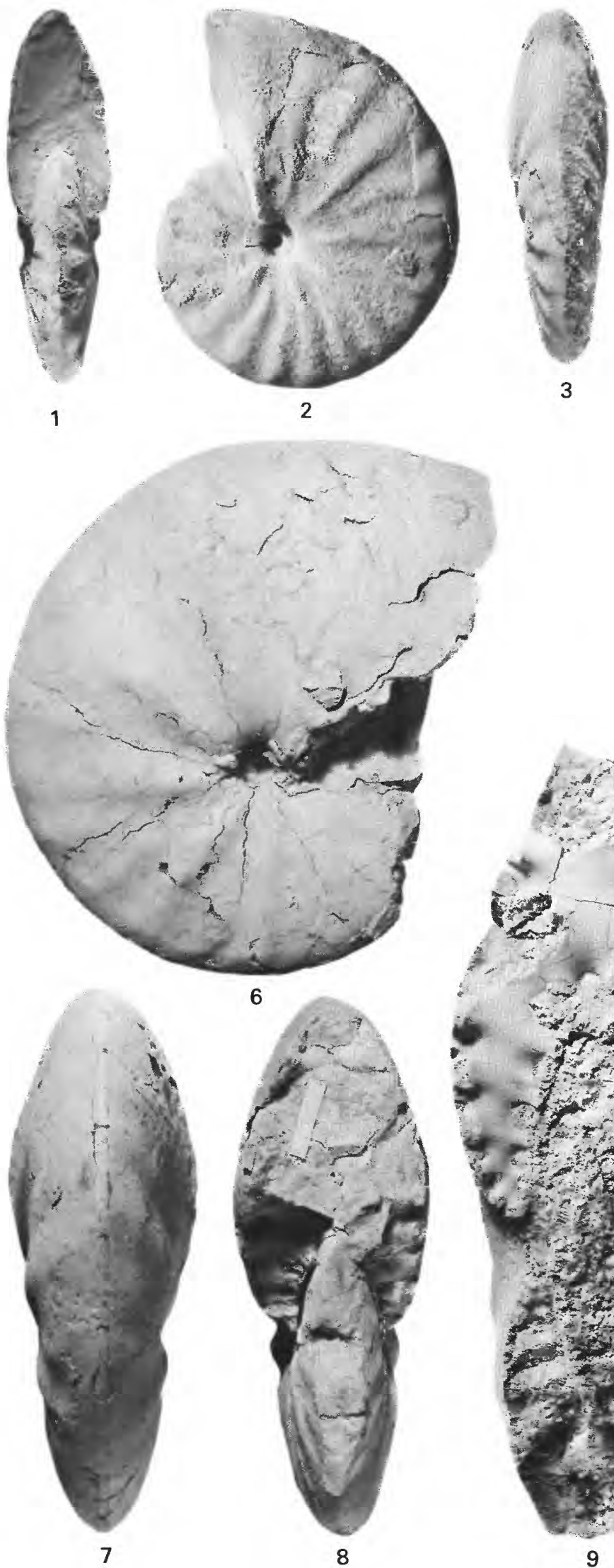

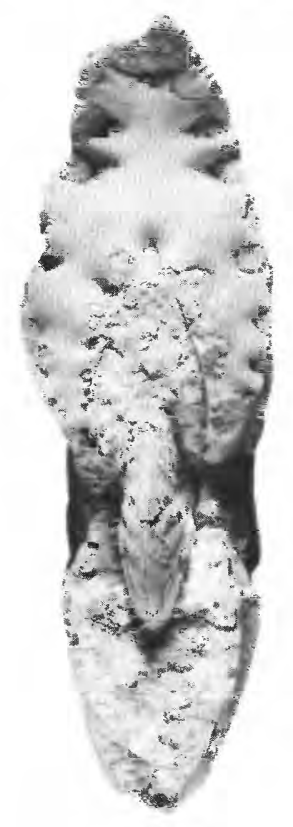

4

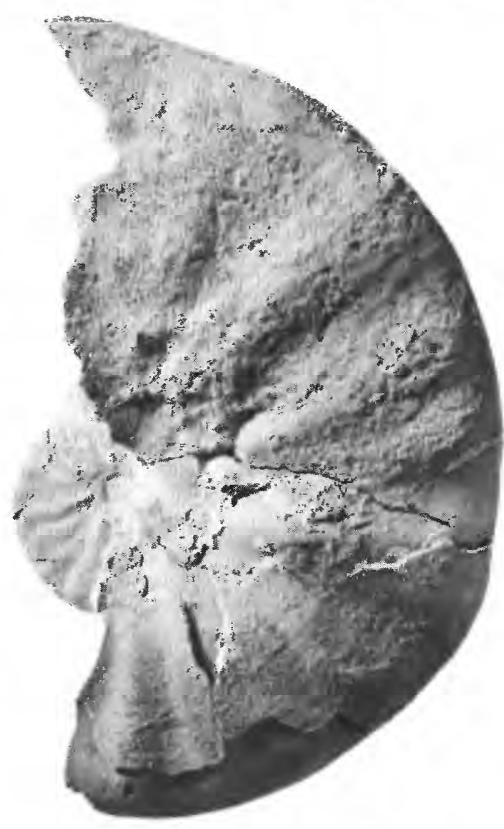

5

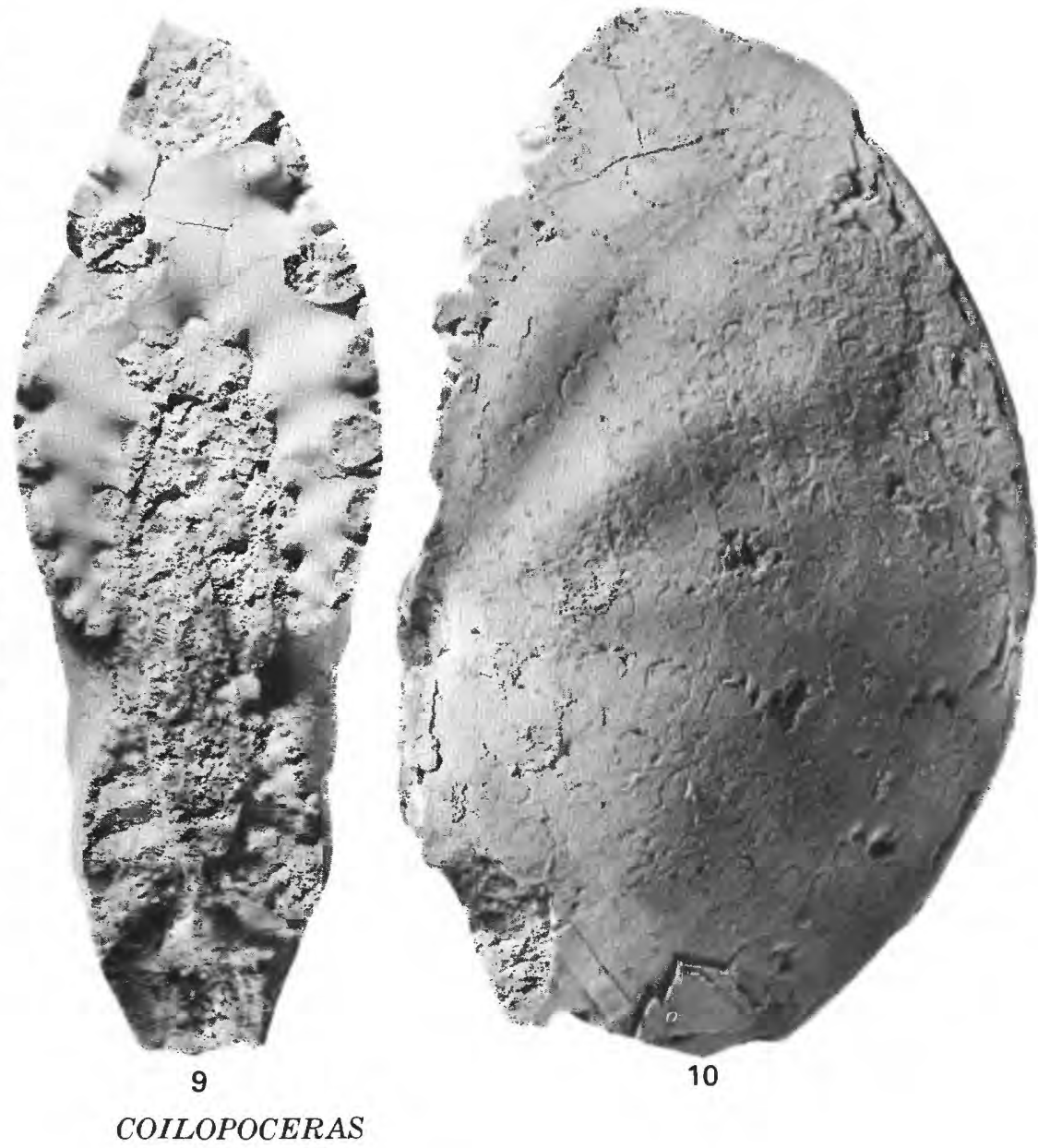




\section{PLATE 7}

[All figures natural size]

Figures 1-9. Coilopoceras colleti Hyatt (p. 13).

From USGS Mesozoic locality D4395 (text fig. 1, loc. 3).

1, 2. Hypotype USNM 275900.

3,4 . Hypotype USNM 275901.

5 , 6. Hypotype USNM 275902.

7-9. Hypotype USNM 275903. 

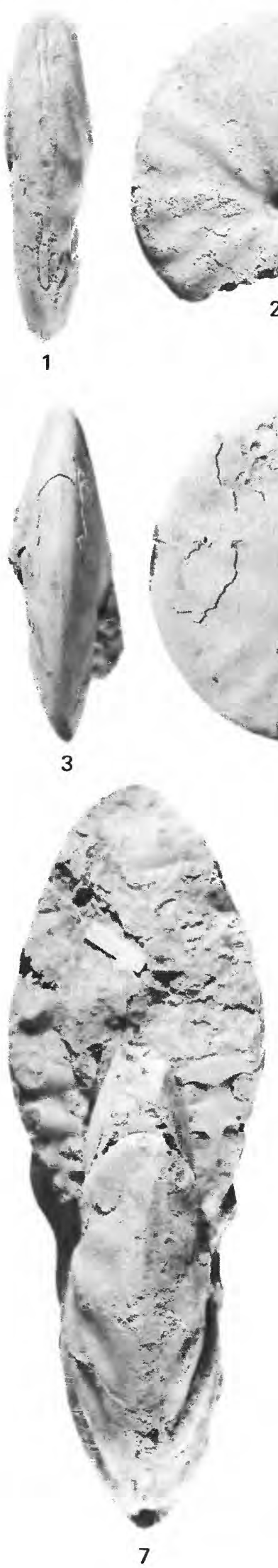
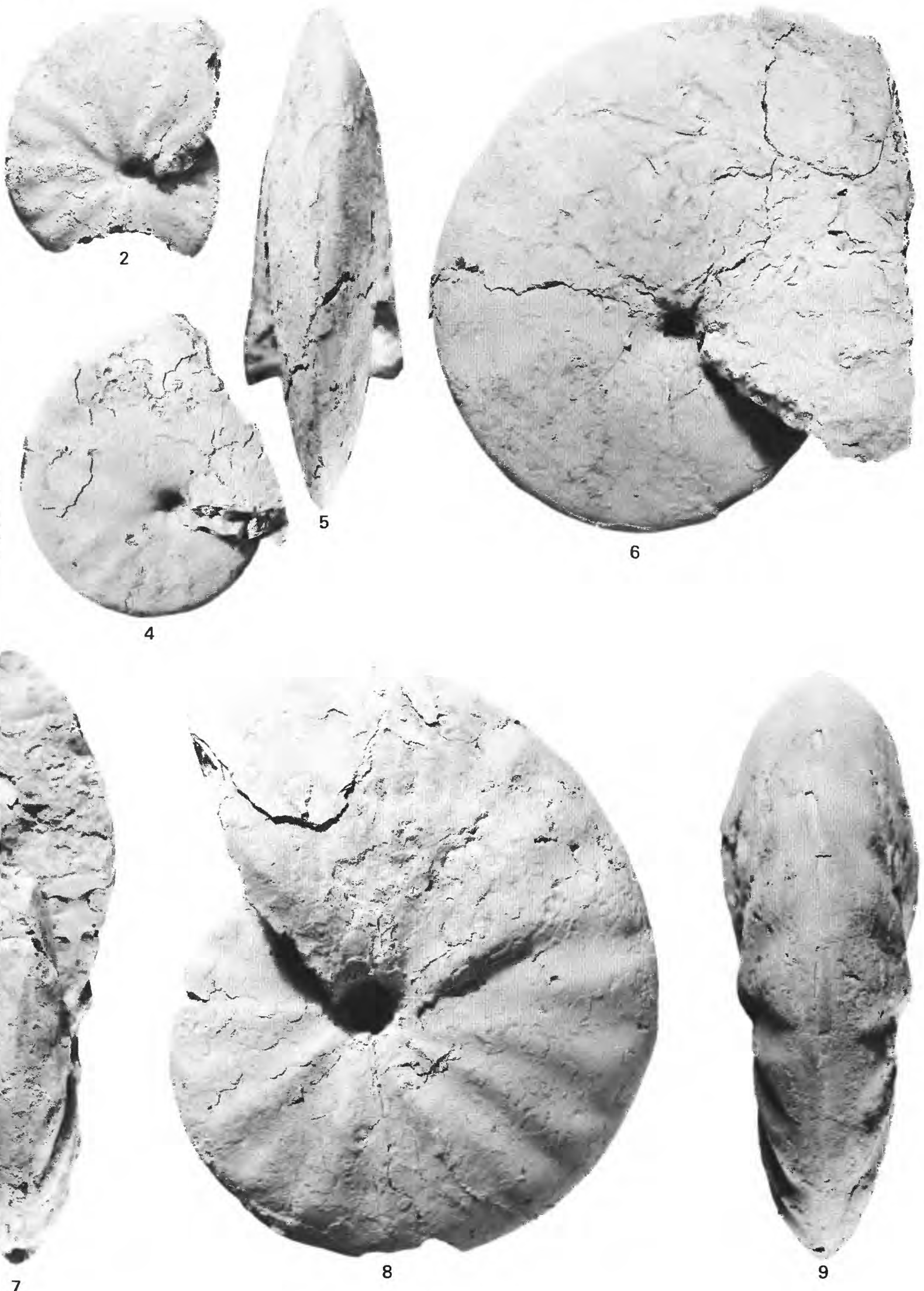

COILOPOCERAS 


\section{PLATE 8}

[Figure about seven-tenths natural size]

Coilopoceras colleti Hyatt (p. 13).

Side view of hypotype USNM 275904, from USGS Mesozoic locality D10354 (text fig. 1, loc. 51). See plate 9 for end views of this large adult and text figure 9 for cross section. 


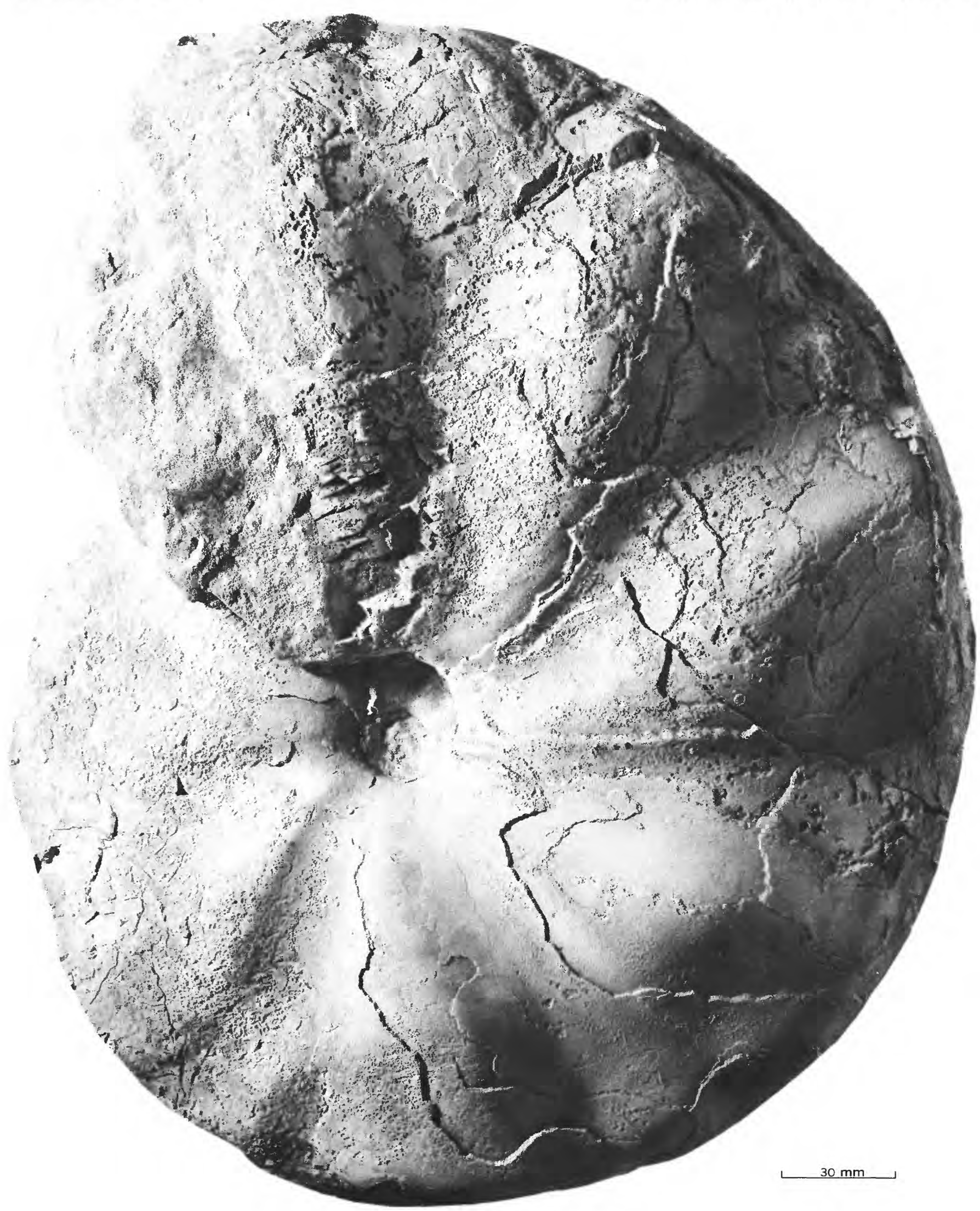




\section{PLATE 9}

[Figures about seven-tenths natural size]

Coilopoceras colleti Hyatt (p. 13).

End views of hypotype USNM 275904, from USGS Mesozoic locality D10354 (text fig. 1, loc. 51). See plate 8 for side view and text figure 9 for cross section. 
GEOLOGICAL SURVEY

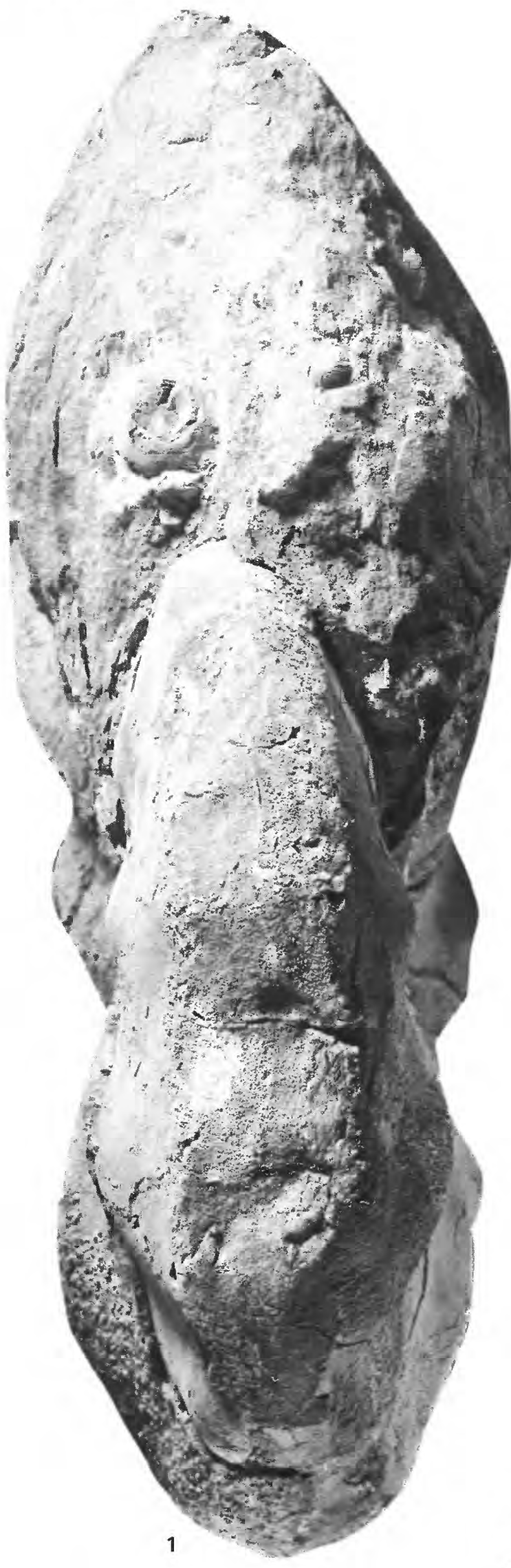

PROFESSIONAL PAPER 1192

PLATE 9

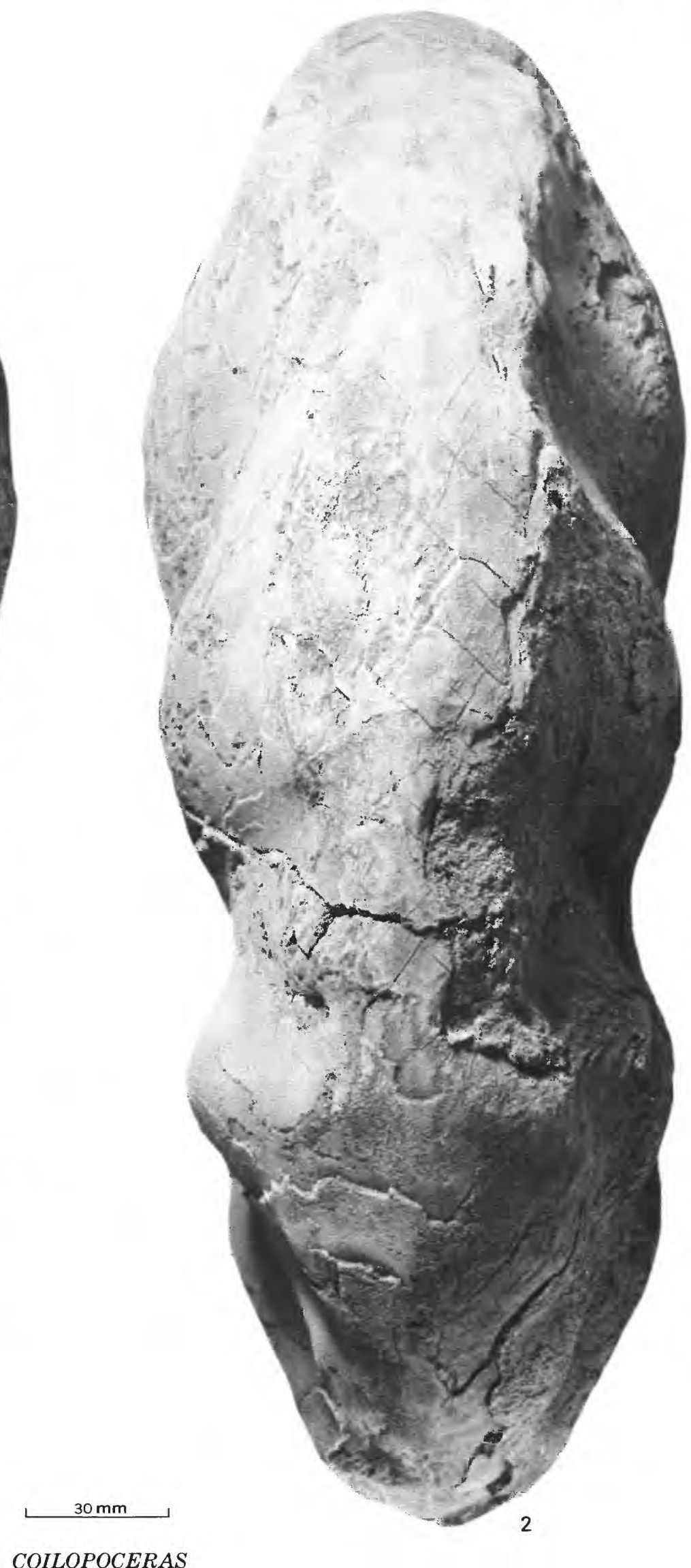




\section{PLATE 10}

[All figures natural size]

Figures 1-8. Coilopoceras springeri Hyatt (p. 16).

From type locality of Semilla Sandstone Member of Mancos Shale at USGS Mesozoic locality 28873 (text fig. 1, loc. 13).

1, 2. Hypotype USNM 275908.

3-5. Hypotype USNM 275909.

6-8. Hypotype USNM 275910. 

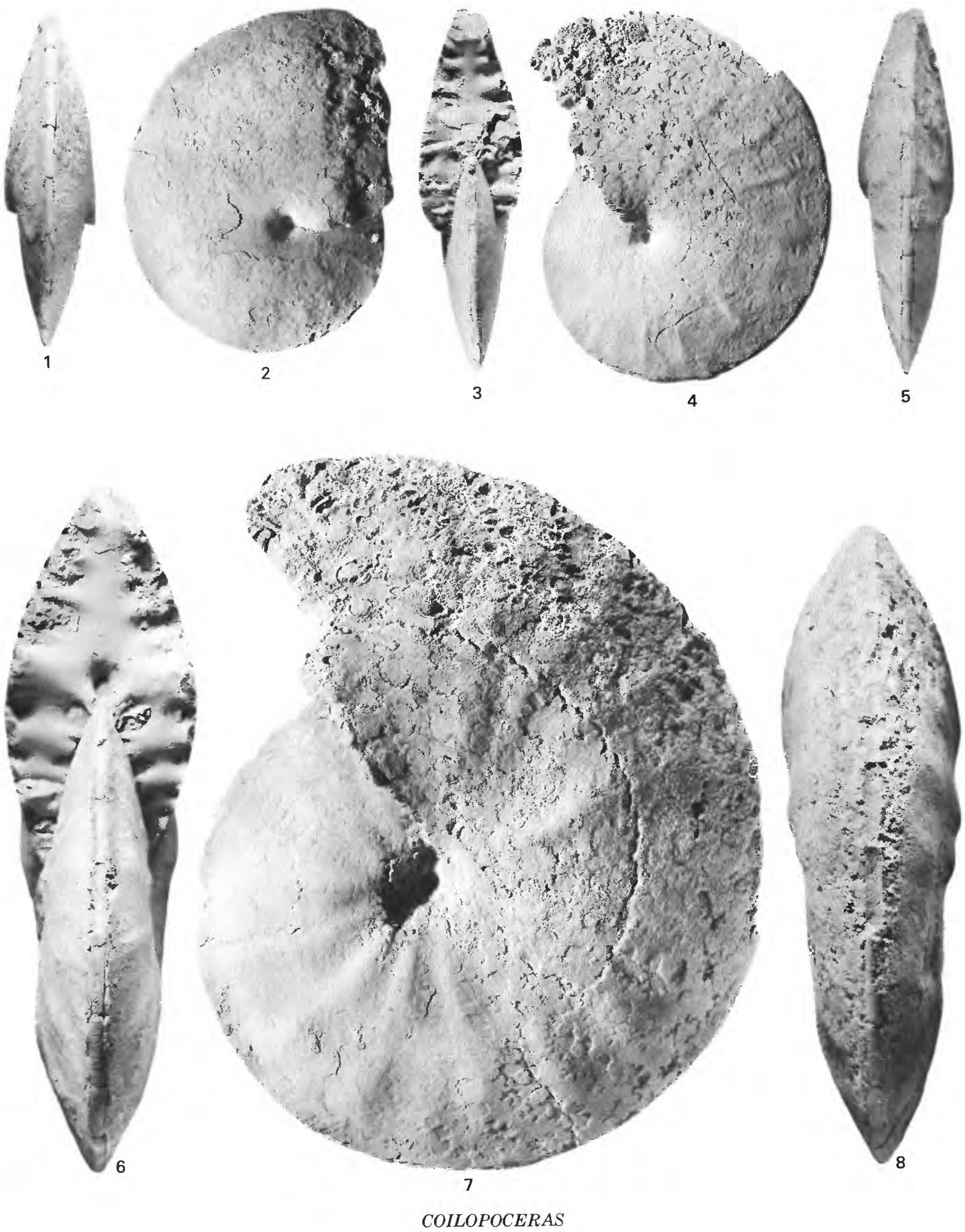
PLATE 11

[Figure 1 natural size; figure 2 slightly smaller than natural size]

FigURE 1. Hoplitoides sandovalensis Cobban and Hook, n. sp. (p. 8).

Paratype USNM 275884, from USGS Mesozoic locality D10508 (text fig. 1, loc. 27). See plate 4 for side view and text figure $7 C$ for suture.

2. Coilopoceras inflatum Cobban and Hook, n. sp. (p. 19).

Sectional view of the holotype USNM 275920, from USGS Mesozoic locality D2055 (text fig. 1, loc. 40). See text figure 15A for suture. 

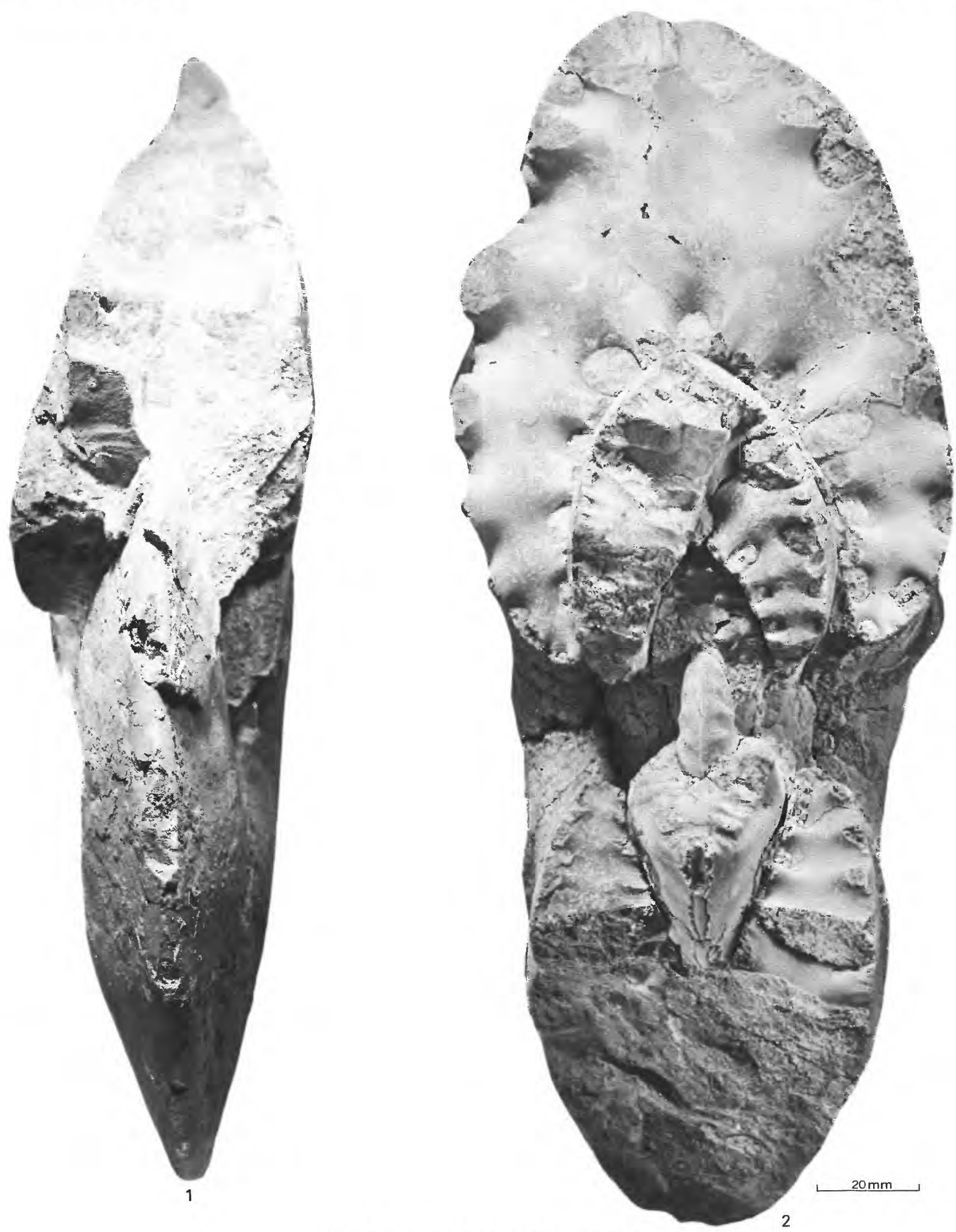

HOPLITOIDES AND COILOPOCERAS 


\section{PLATE 12}

[Figure about three-fourths natural size]

Coilopoceras inflatum Cobban and Hook, n. sp. (p. 19).

Side view of paratype USNM 275922, from USGS Mesozoic locality D10321 (text fig. 1, loc. 38). See plate 13, figure 2 , for end view and text figure $14 A$ for cross section. 


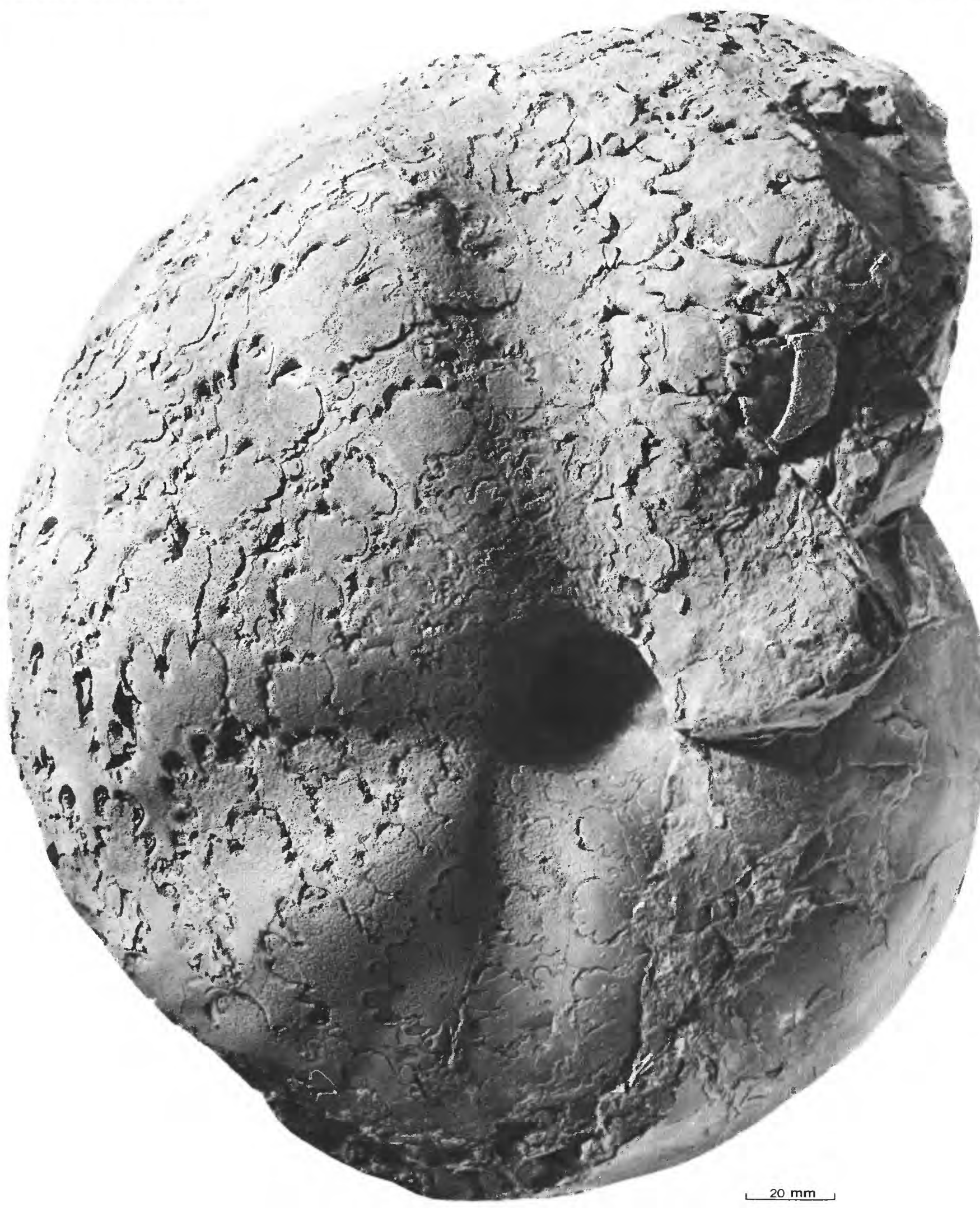

COILOPOCERAS 


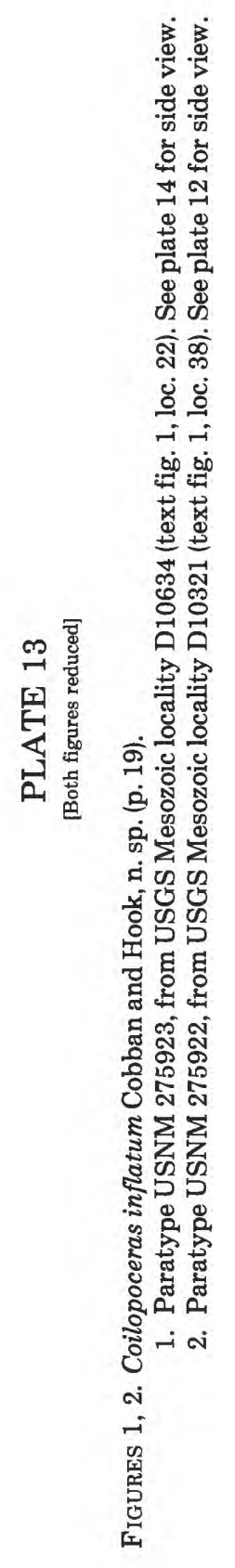


焉

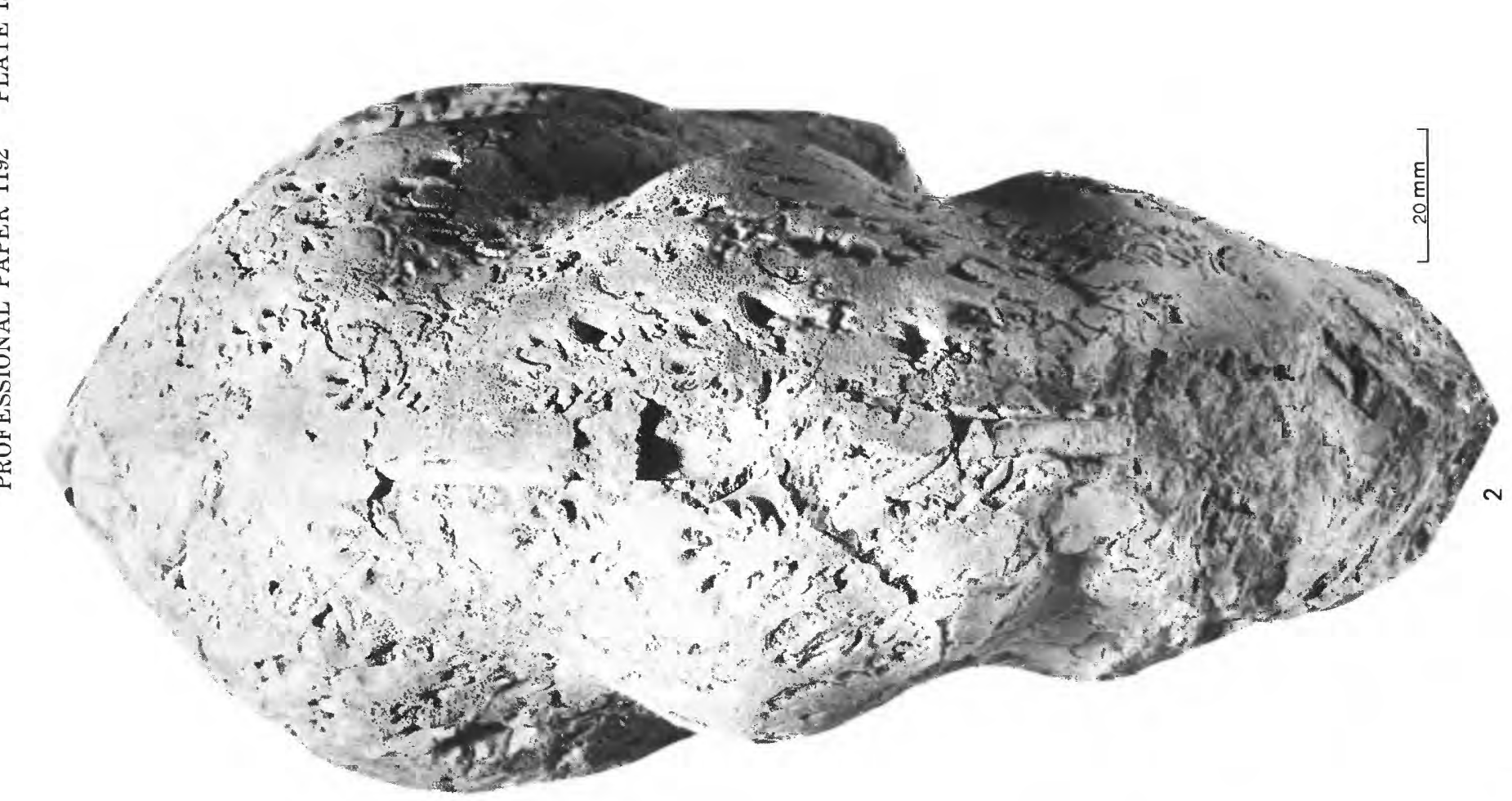

0
0
0
0
0
0
0
0

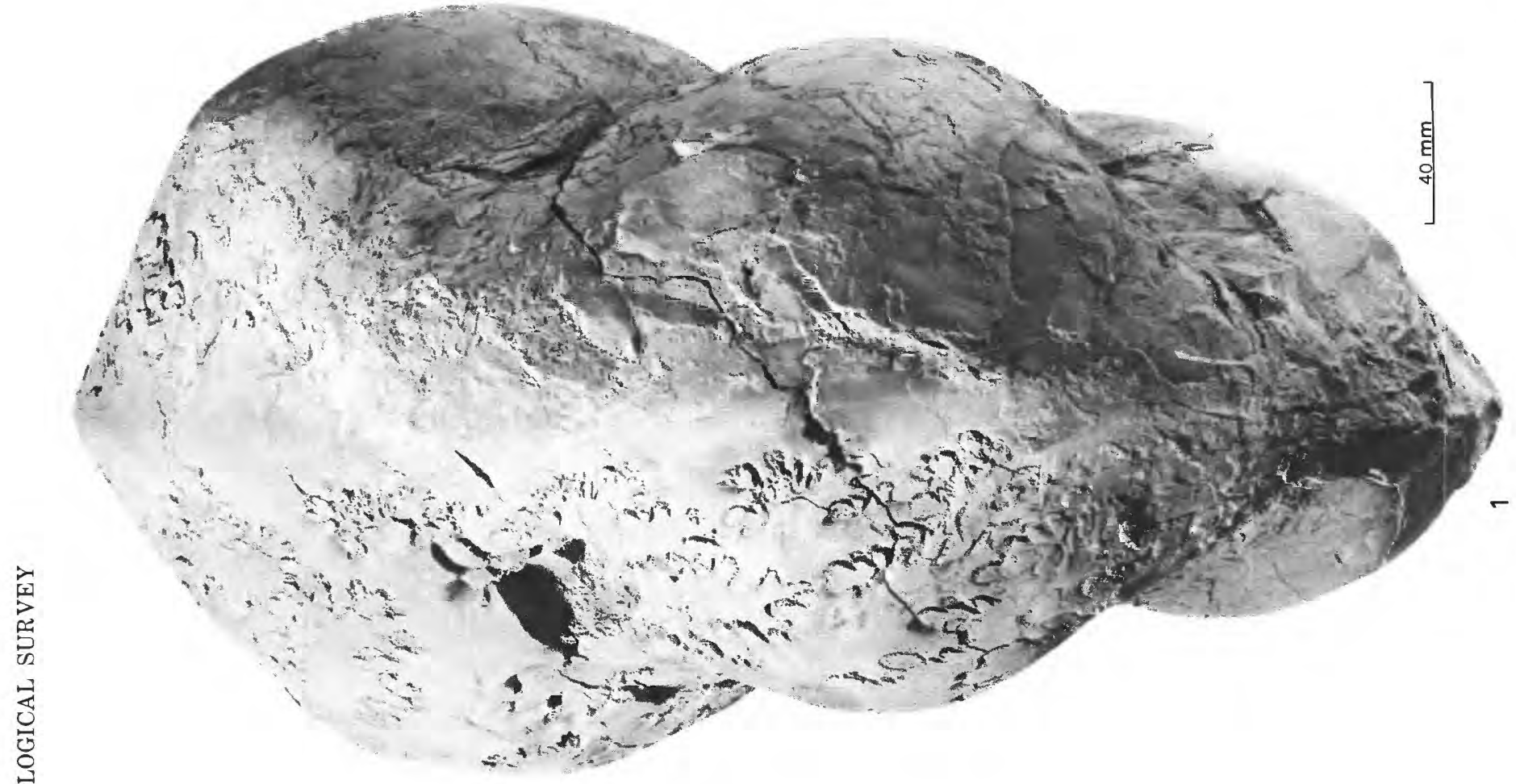




\section{PLATE 14}

[Figure about six-tenths natural size]

Coilopoceras inflatum Cobban and Hook, n. sp. (p. 19).

Side view of paratype USNM 275923, from USGS Mesozoic locality D10534 (text fig. 1, loc. 22). See plate 13, figure 1, for end view and text figure $14 \mathrm{C}$ for whorl section. This huge specimen was collected by L. F. Gunther, Brigham City, Utah. 


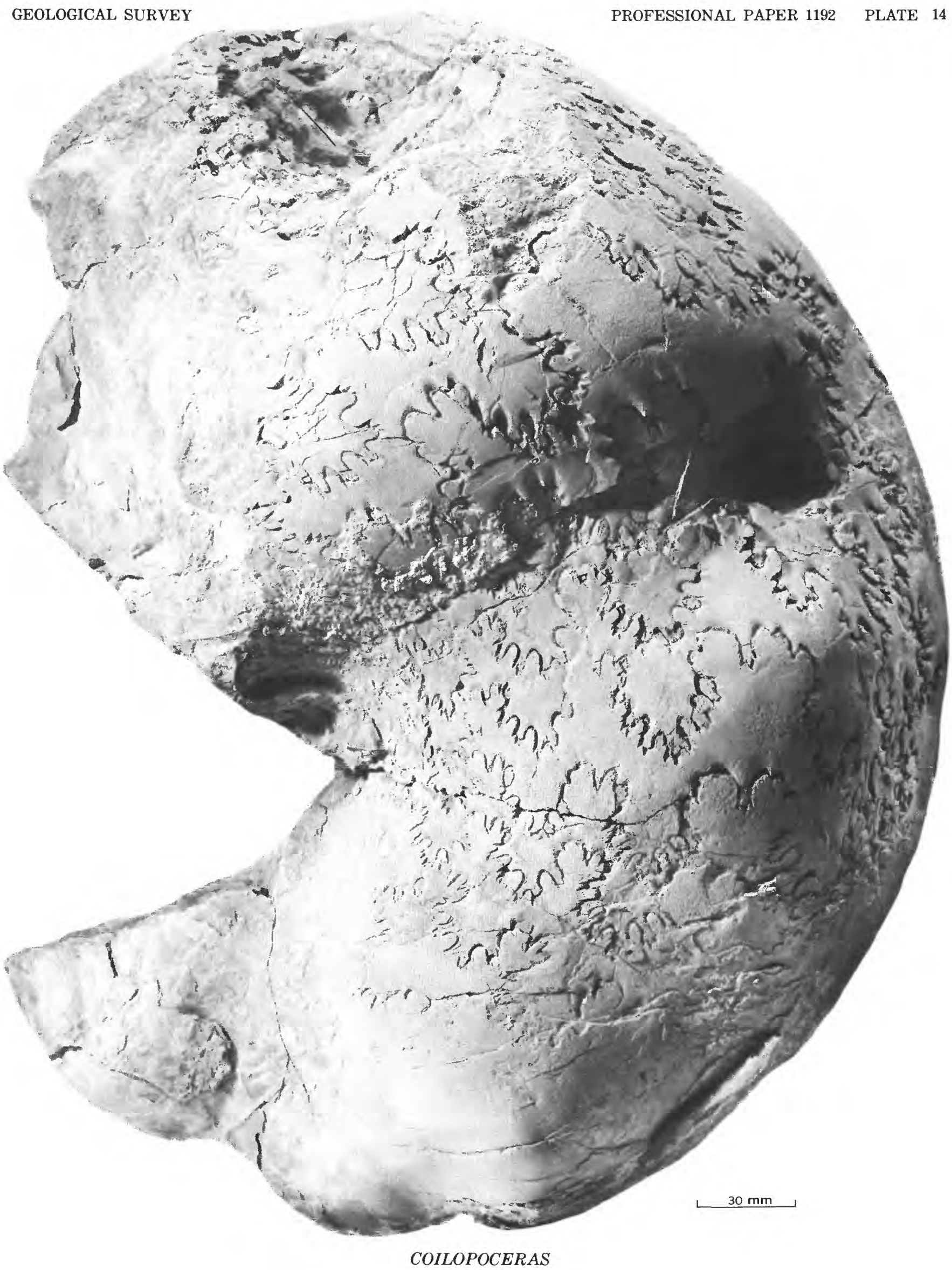




\section{PLATE 15}

[Figure natural size]

Coilopoceras inflatum Cobban and Hook, n. sp. (p. 19).

Paratype USNM 275924, from USGS Mesozoic locality D10299 (text fig. 1, loc. 43). See plate 16, figures 1 and 2, for end views. 


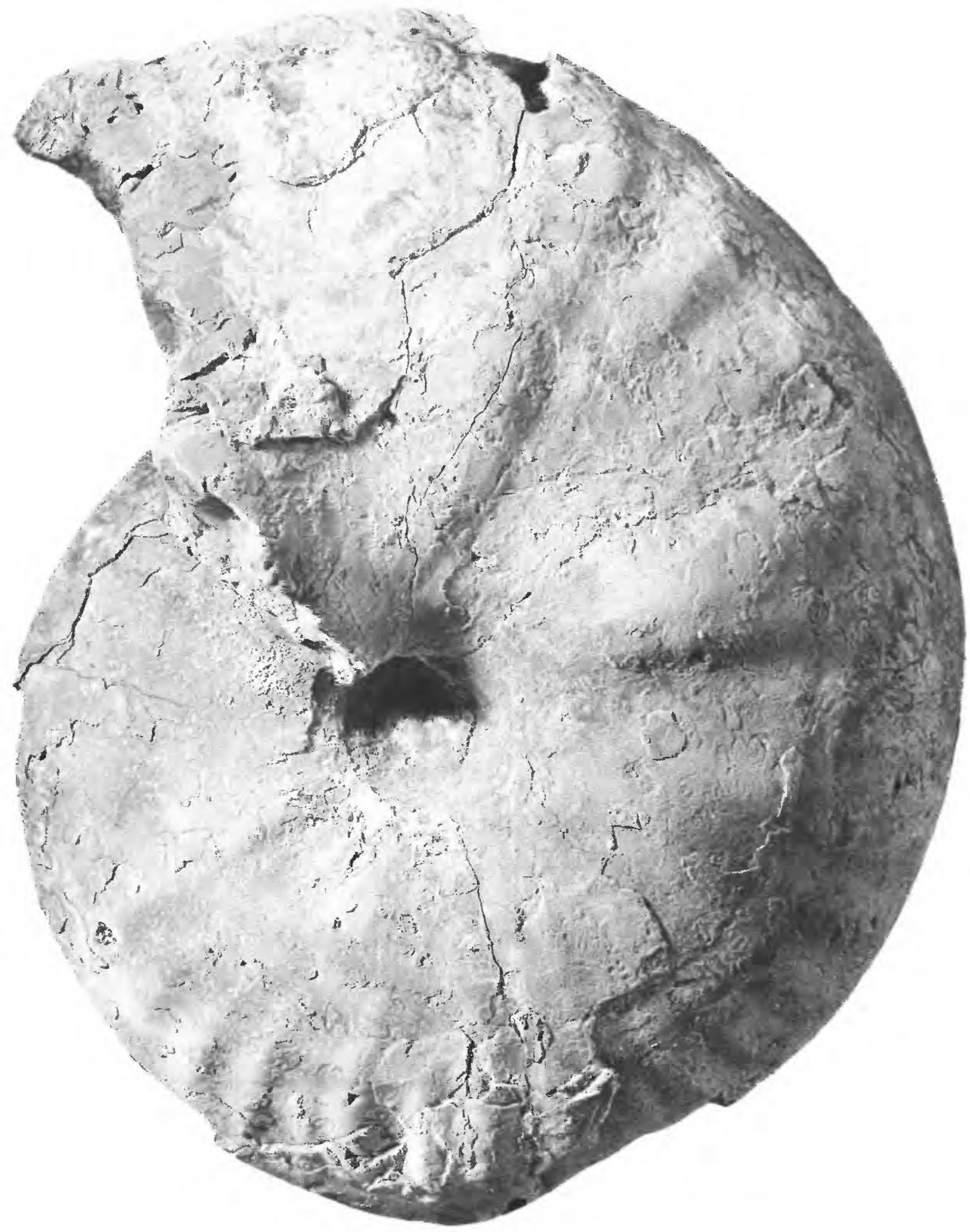

COILOPOCERAS 


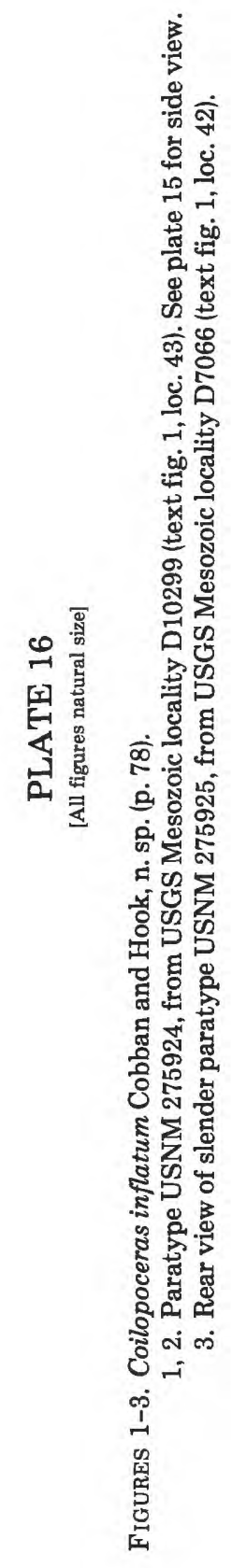


是
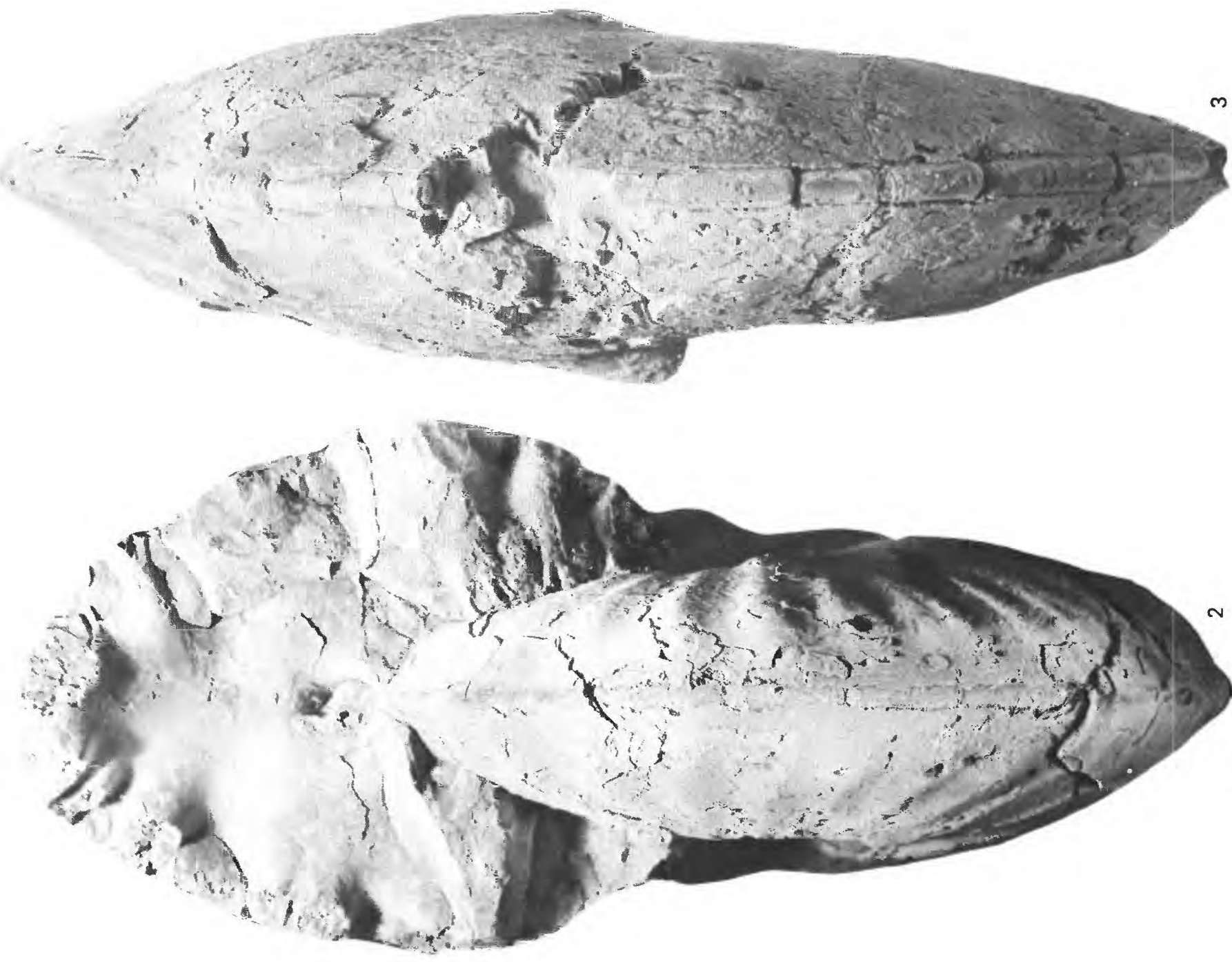

0
0
0
0
0
0
0
0
0

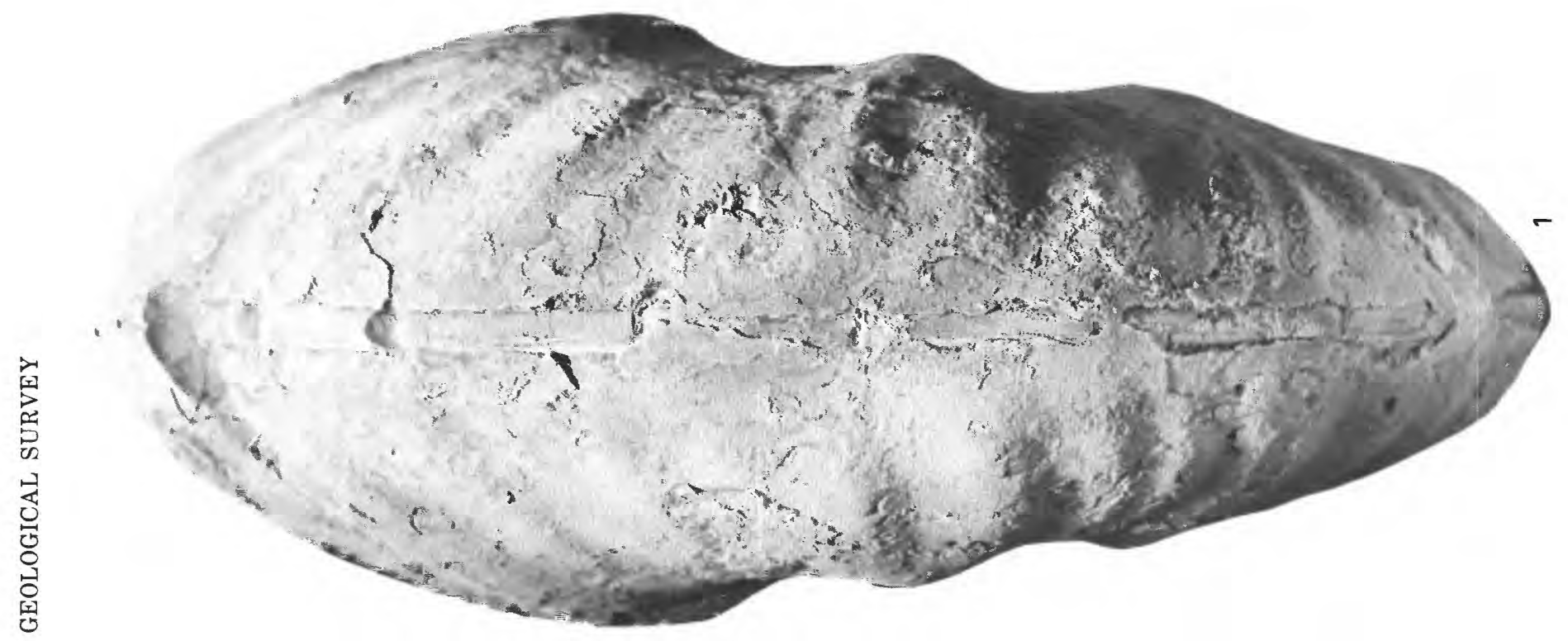




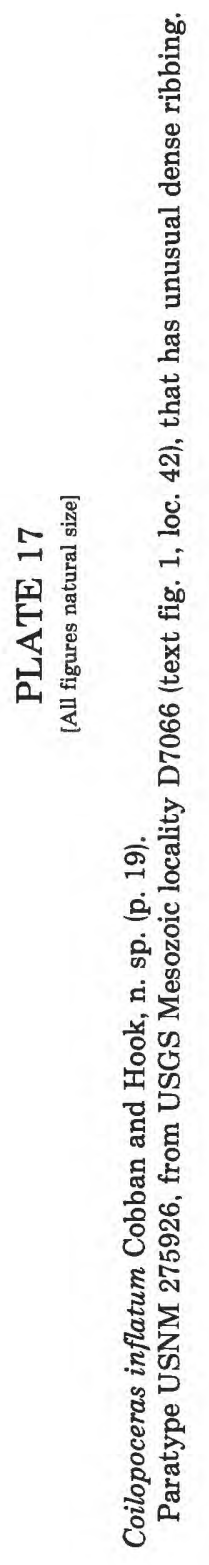




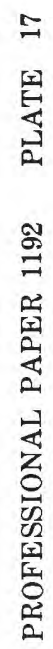
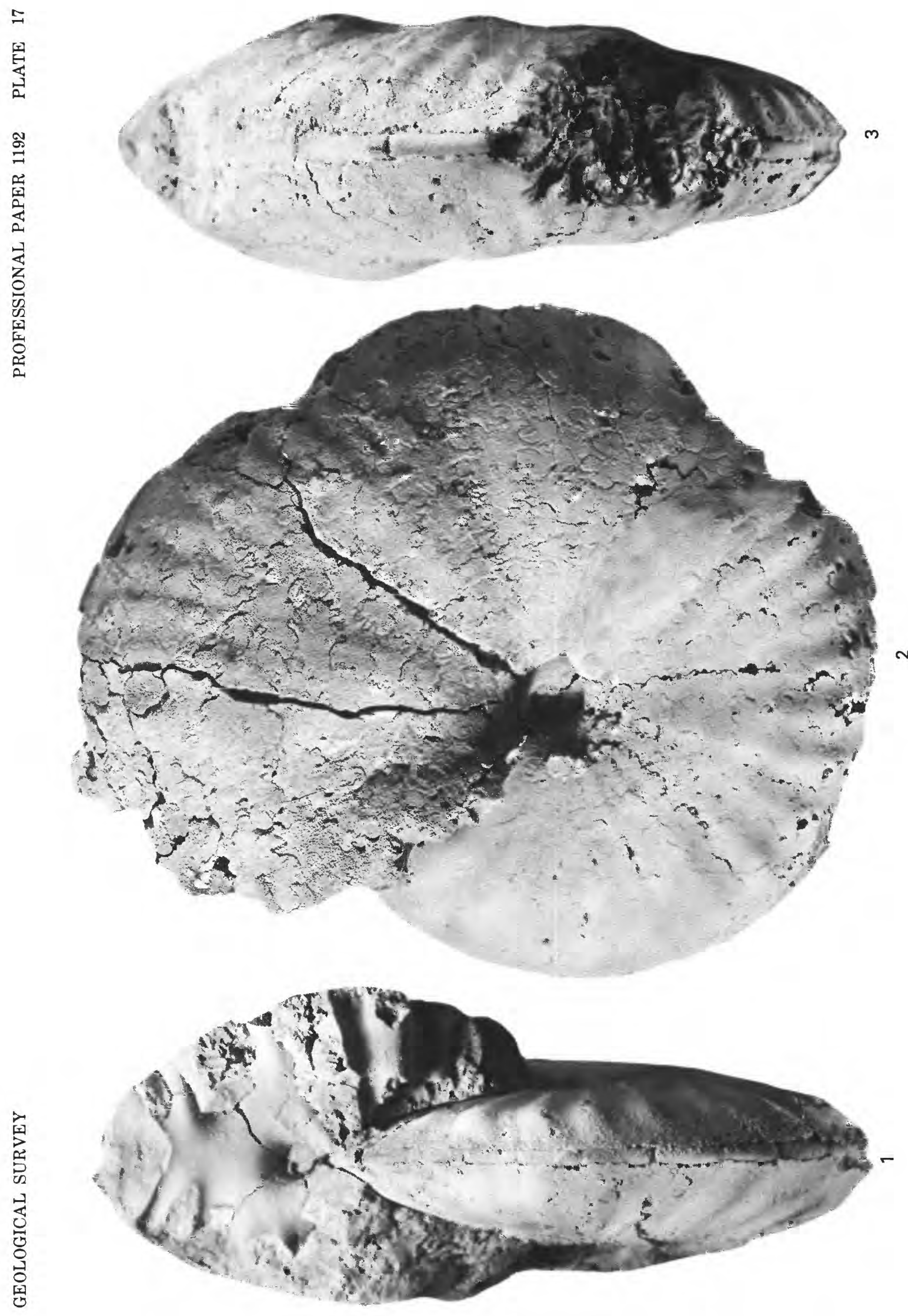


\section{PLATE 18}

[All figures natural size]

Figures 1-3, 11-13. Coilopoceras inflatum Cobban and Hook, n. sp. (p. 19).

1-3. Paratype USNM 275927, from USGS Mesozoic locality D10644 (text fig. 1, loc. 55).

11-13. Paratype USNM 275928, from USGS Mesozoic locality 26203 (text fig. 1, loc. 44).

4-6. Hoplitoides sandovalensis Cobban and Hook, n. sp. (p. 8).

Paratype USNM 275885, from USGS Mesozoic locality D10508 (text fig. 1, loc. 27). See text figure 6 for cross section.

7-10. Coilopoceras springeri Hyatt (p. 16).

7, 8. Hypotype USNM 275911, from USGS Mesozoic locality 22873 (text fig. 1, loc. 13). This unusual specimen resembles $C$. colleti Hyatt in its umbilical bullae and lateral ribs.

9, 10. Hypotype USNM 275912, from USGS Mesozoic locality D4014 (text fig. 1, loc. 11). 

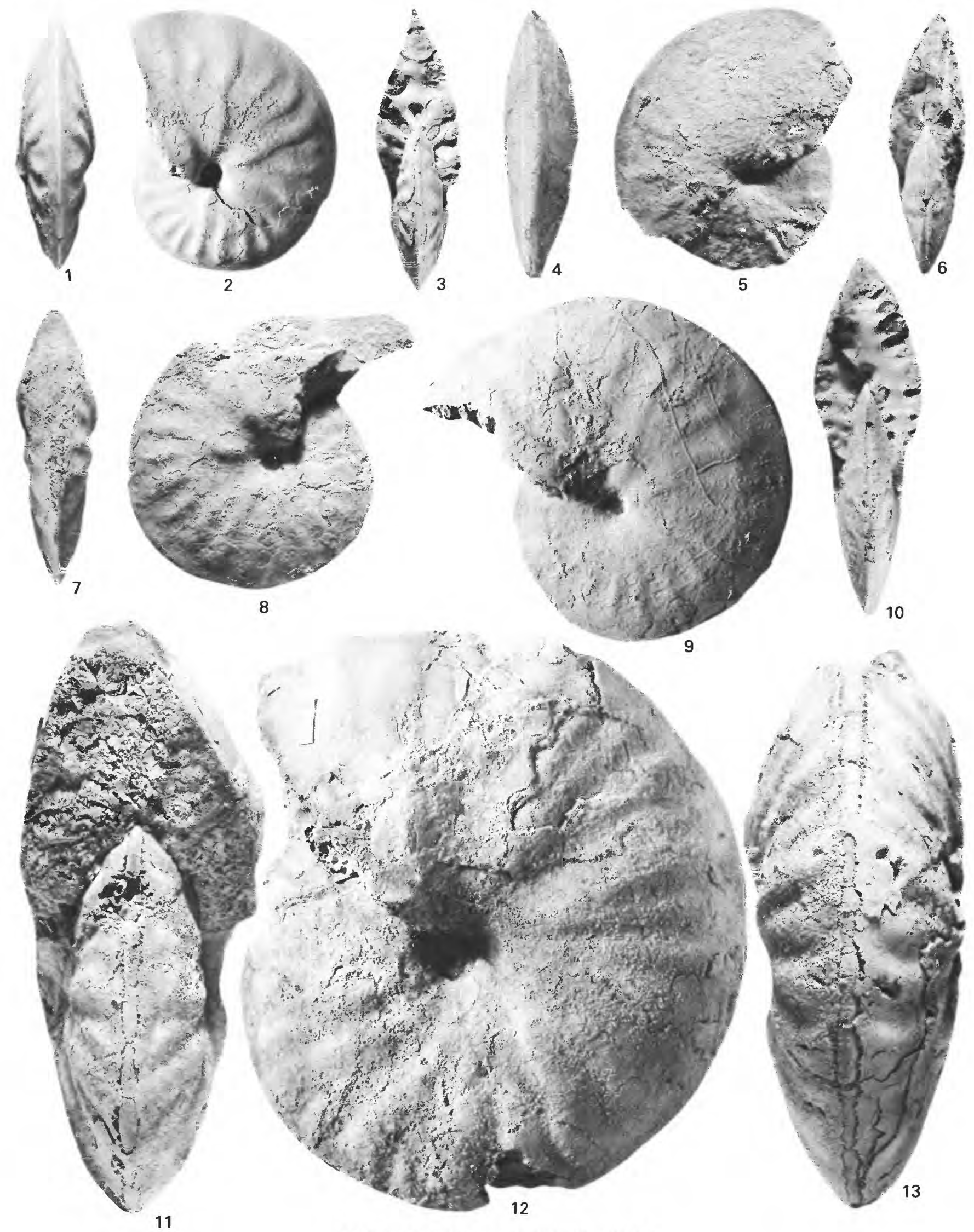

COILOPOCERAS AND HOPLITOIDES 


\section{PLATE 19}

[All figures natural size except as indicated]

Figures 10-18. Coilopoceras springeri Hyatt (p. 16).

1-3. Hypotype USNM 275913, from USGS Mesozoic locality 28873 (text fig. 1, loc. 13).

4-6. Hypotype USNM 275914, from USGS Mesozoic locality D10575 (text fig. 1, loc. 21).

7-9. Hypotype USNM 275915, from USGS Mesozoic locality D3884 (text fig. 1, loc. 10).

10-18. Herrickiceras costatum (Herrick and Johnson) (p. 23).

10-12. Hypotype USNM 275941, from USGS Mesozoic locality D10469 (text fig. 1, loc. 32). See text figure $16 \mathrm{~A}$ for suture.

13-15. Hypotype USNM 275942, from the same locality. See text figure $16 B$ for suture.

16-18. Neotype USNM 275940, from USGS Mesozoic locality D10508 (text fig. 1, loc. 27). See text figure $16 C$ for suture. 

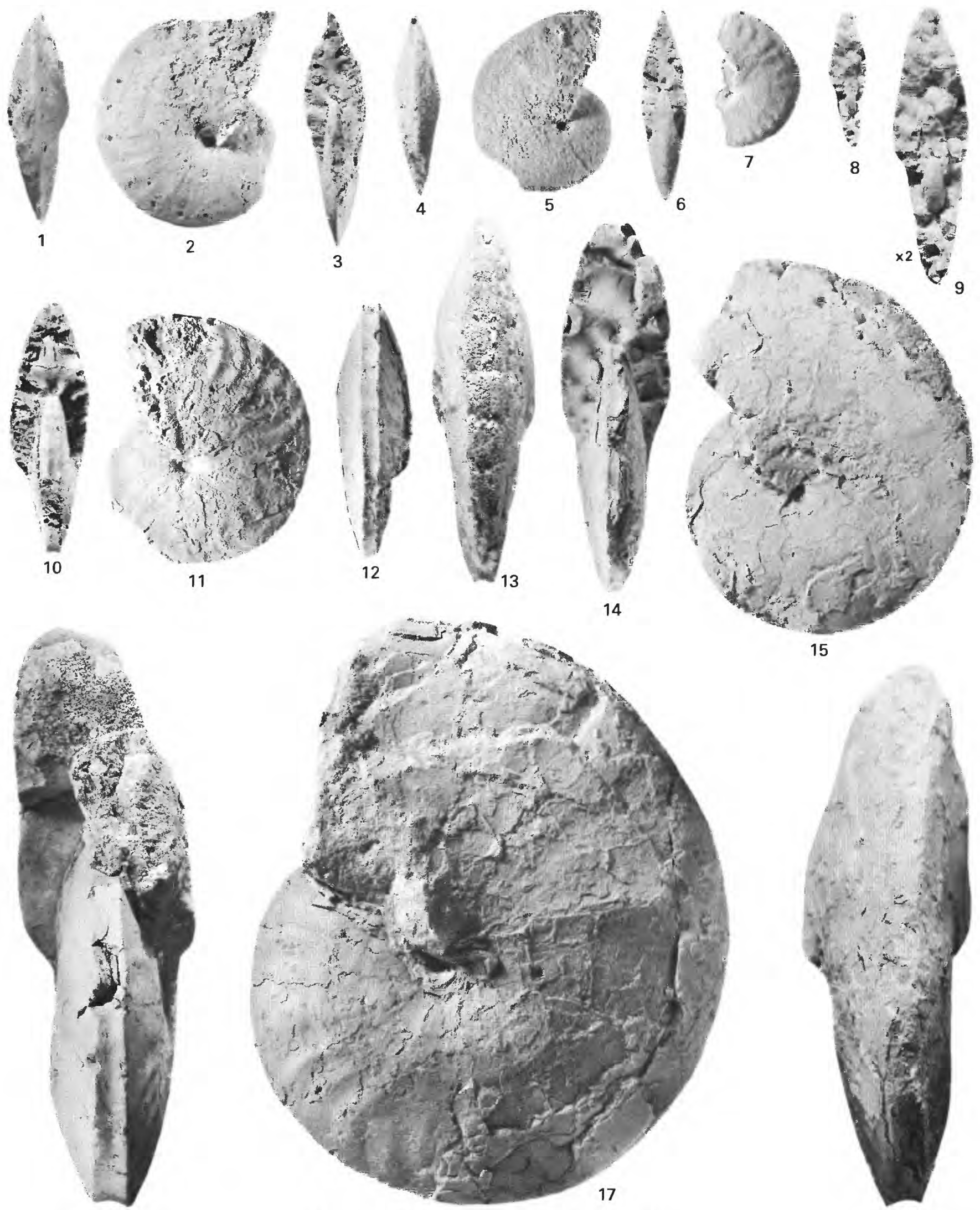

15

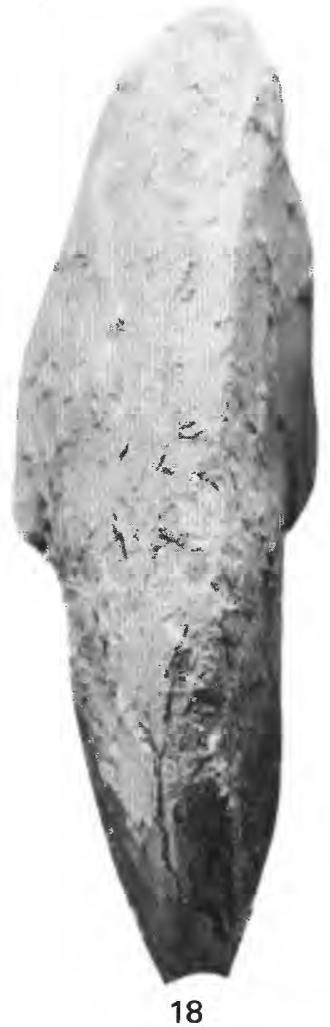

COILOPOCERAS AND HERRICKICERAS 
PLATE 20

[All figures natural size]

Figures 1-16. Coilopoceras inflatum Cobban and Hook, n. sp. (p. 19).

From USGS Mesozoic locality D10636 (text fig. 1, loc. 54).

1, 2. Paratype USNM 275929.

3-5. Paratype USNM 275930.

6-8. Paratype USNM 275931.

9-10. Paratype USNM 275932.

12, 13. Paratype USNM 275933.

14-16. Paratype USNM 275934. 


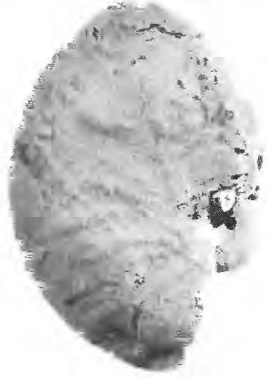

1
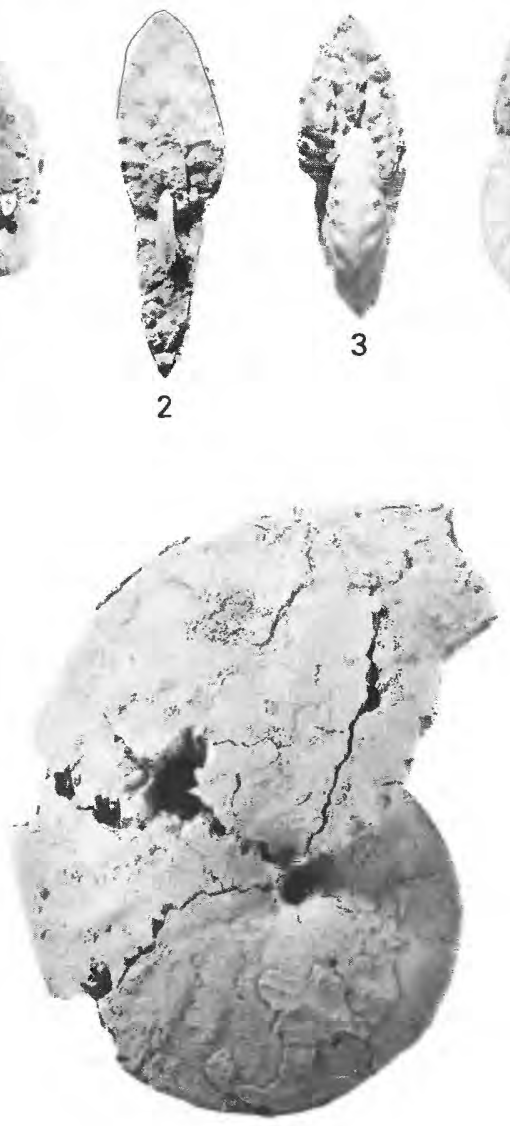

10

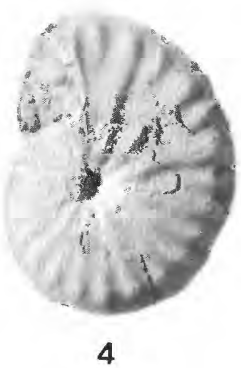

4

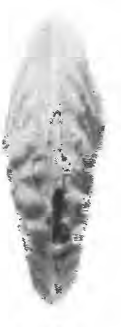

5
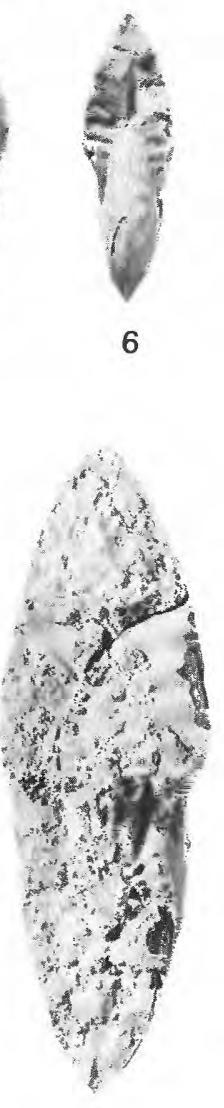

12

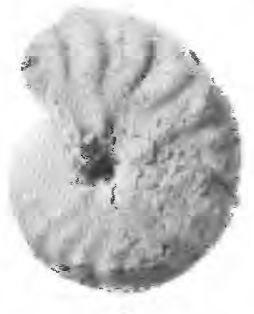

7

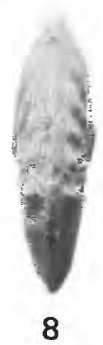

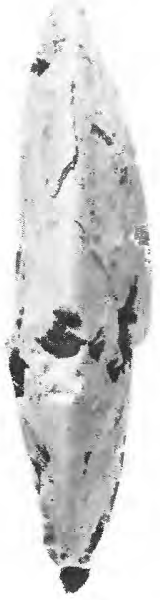

9

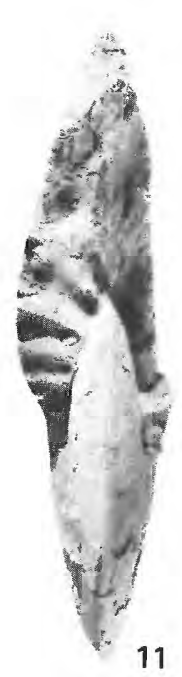

11
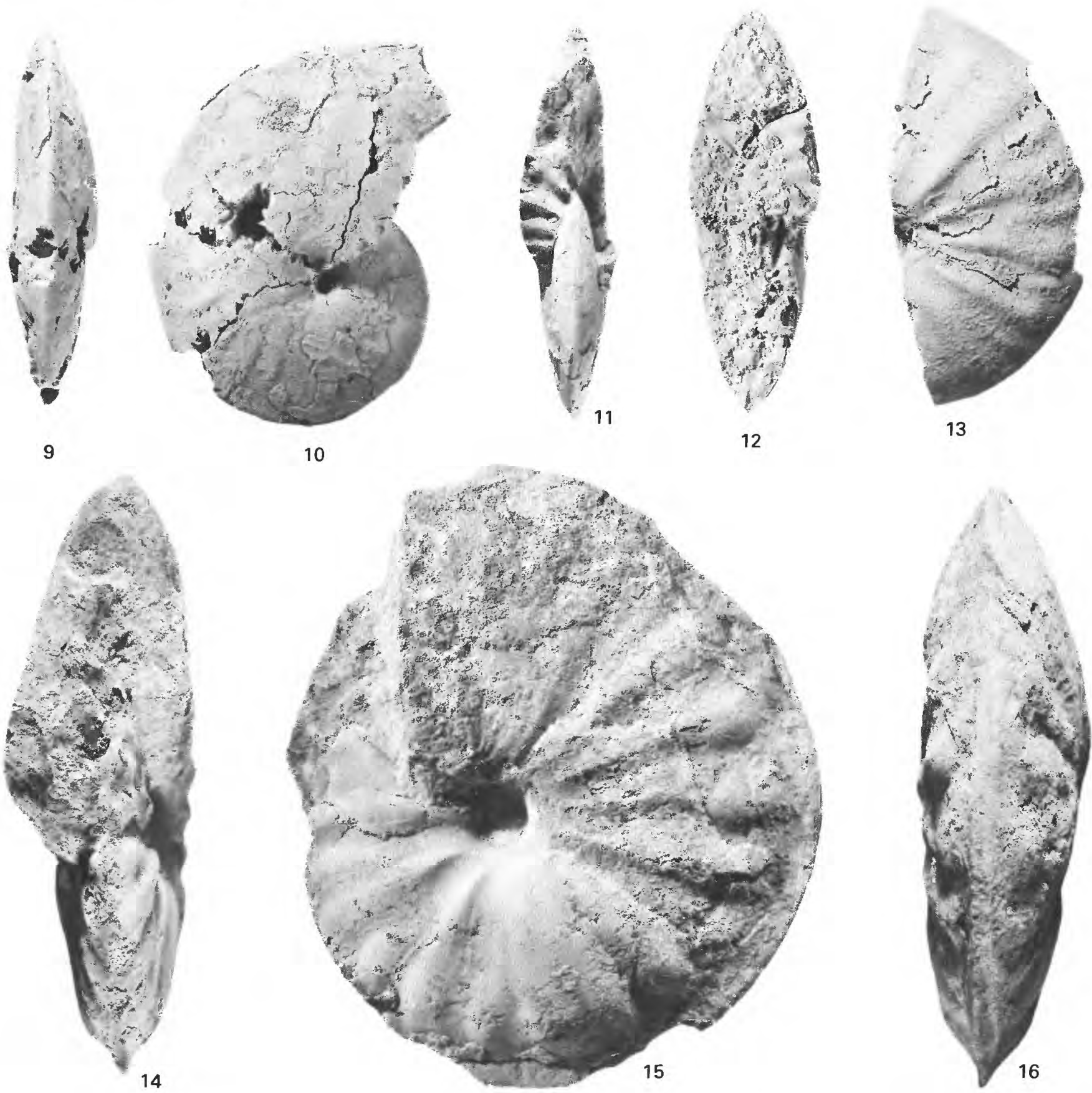

COILOPOCERAS 


\section{PLATE 21}

[All figures natural size]

Figures 1-5. Coilopoceras inflatum Cobban and Hook, n. sp. (p. 19).

1, 3. Paratype USNM 275935, from USGS Mesozoic locality D10636 (text fig. 1, loc. 54).

2. Paratype USNM 275936, from USGS Mesozoic locality D10638 (text fig. 1, loc. 41).

4, 5. Paratype USNM 275937, from USGS Mesozoic locality D10644 (text fig. 1, loc. 55). 


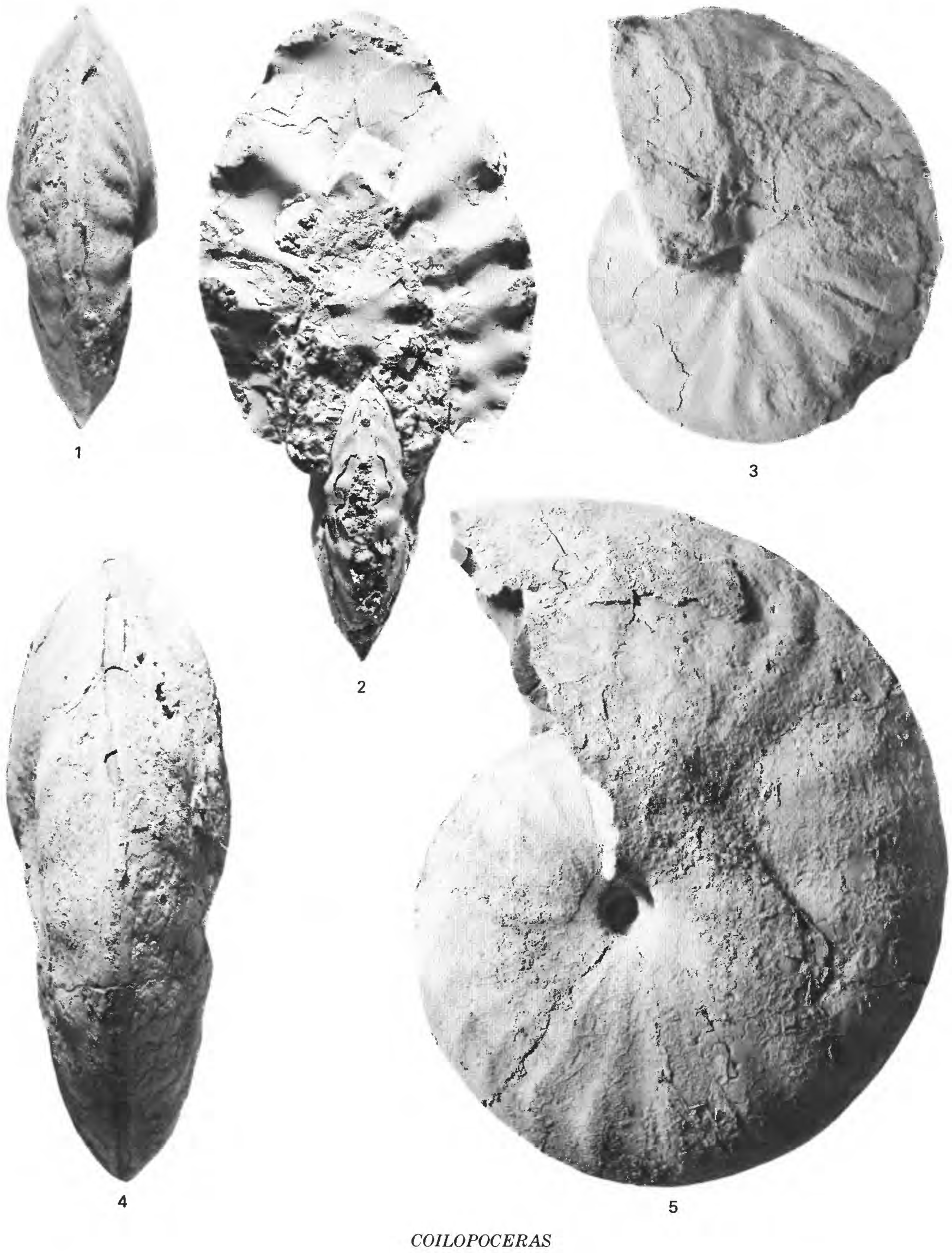

